\title{
Cook Islands: Assessment of the Supervision and Regulation of the Financial Sector Volume II-Detailed Assessment of Observance of Standards and Codes
}

This detailed assessment of observance of standards and codes in the financial sector of the Cook Islands in the context of the offshore financial center assessment program contains technical advice and recommendations given by the staff team of the International Monetary Fund in response to the authorities of the Cook Islands' request for technical assistance. It is based on the information available at the time it was completed in October 2004. The staff's overall assessment relating to financial sector regulation and supervision can be found in Volume I. The views expressed in these documents are those of the staff team and do not necessarily reflect the views of the government of the Cook Islands or the Executive Board of the IMF.

The policy of publication of staff reports and other documents by the IMF allows for the deletion of market-sensitive information.

To assist the IMF in evaluating the publication policy, reader comments are invited and may be sent by e-mail to publicationpolicy@imf.org.

Copies of this report are available to the public from

International Monetary Fund $\bullet$ Publication Services

700 19th Street, N.W. • Washington, D.C. 20431

Telephone: (202) 6237430 • Telefax: (202) 6237201

E-mail: publications@imf.org • Internet: http://www.imf.org

Price: $\$ 15.00$ a copy

\section{International Monetary Fund Washington, D.C.}



ASSESSMENT OF THE SUPERVISION AND REGULATION OF THE FinANCIAL SECTOR

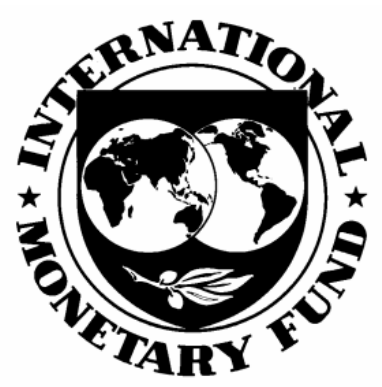

Volume II: Detailed Assessment of Observance of Standards and Codes

Cook Islands

OCTOBER 2004 
"The contents of this report constitute technical advice and recommendations given by the staff of the International Monetary Fund (IMF) to the Cook Islands in response to their request for technical assistance. With the written authorization of the recipient country's authorities, this report (in whole or in part) or summaries thereof may be disclosed to IMF Executive Directors and their staff, and to technical assistance providers and donors outside the IMF. Disclosure of this report (in whole or in part) or summaries thereof to parties outside the IMF other than technical assistance providers and donors shall require the written authorization of the recipient country's authorities and the IMF's Monetary and Financial Systems Department." 
Glossary.

I. Assessment Of Observance Of The Basel Core Principles For Effective Banking Supervision

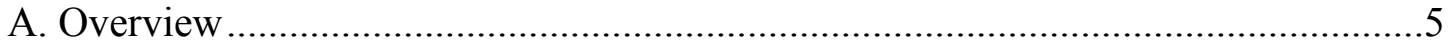

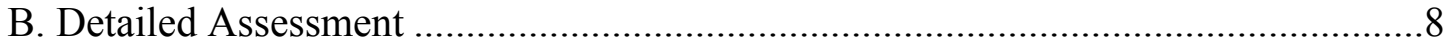

C. Summary Compliance of the Basel Core Principles ............................................ 32

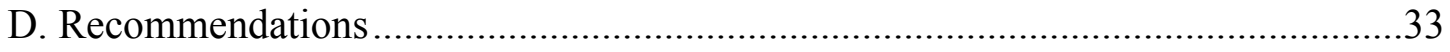

II. Detailed Assessment Report on Anti-Money Laundering and Combating

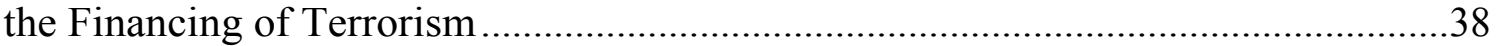

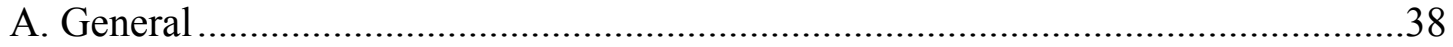

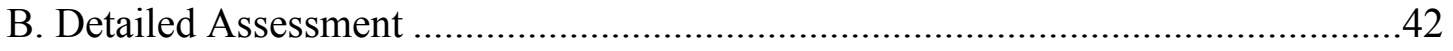

C. Ratings of Compliance with FATF Recommendations, Summary of Effectiveness of AML/CFT efforts, Recommended Action Plan and Authorities' Response to the Assessment.....

Tables

1. Detailed Assessment of Compliance of the Basel Core Principles................................8

2. Summary Compliance of the Basel Core Principles..................................................32

3. Recommended Action Plan to Improve Compliance of the Basel Core Principle ...........33

4. Detailed Assessment of Criminal Justice Measures and International Cooperation .......42

5. Detailed Assessment of the Legal and Institutional Framework for Financial Institutions and its Effective Implementation ........................................................69

6. Description of the Controls and Monitoring of Cash and Cross-Border Transactions....86

7. Ratings of Compliance with FATF Recommendations Requiring Specific Action ........86

8. Summary of Effectiveness of AML/CFT Efforts ......................................................8

9. Recommended Action Plan to Improve the Legal and Institutional Framework and to Strengthen the Implementation of AML/CFT Measures in Banking, Insurance and Securities Sectors 


\section{GLOSSARY}

\begin{tabular}{|c|c|}
\hline AML & Anti-Money Laundering \\
\hline $\mathrm{AML} / \mathrm{CFT}$ & Anti-Money Laundering and Combating the Financing of Terrorism \\
\hline APG & Asia Pacific Group on Money Laundering \\
\hline BA & Banking Act 2003 \\
\hline CA & Crimes Act 1969 \\
\hline CFT & Combating the Financing of terrorism \\
\hline CID & FTRR (Customer Identification) \\
\hline CIG & Cook Islands Government \\
\hline CIP & Cook Islands Police \\
\hline CLAG & Combined Law Agency Group \\
\hline CLO & Crown Law Office \\
\hline CPA & Criminal Procedure Act 1980-81 \\
\hline CPAA & Criminal Procedure Amendment Act 2003 \\
\hline EA & Extradition Act 2003 \\
\hline ER & Extradition Regulations 2004 \\
\hline FATF & Financial Action Task Force on Money Laundering \\
\hline FIU & Financial Intelligence Unit \\
\hline FSC & Financial Services Commission \\
\hline FSCA & Financial Services Commission Act 2003 \\
\hline FT & Financing of Terrorism \\
\hline FTRA & Financial Transactions Reporting Act 2003 \\
\hline FTRR & Financial Transactions Reporting Regulations 2004 \\
\hline IAE & Independent AML/CFT Expert \\
\hline ICA & International Companies Act 1981-82 \\
\hline ICR & International Companies (Evidence of Identity) Regulations 2004 \\
\hline ICSFT & $\begin{array}{l}\text { International Convention for the Suppression of the Financing of } \\
\text { Terrorism }\end{array}$ \\
\hline LEG & Legal Department, IMF \\
\hline MACMA & Mutual Assistance in Criminal Matters Act 2003 \\
\hline MACMAA & Mutual Assistance in Criminal Matters Amendment Act 2003 \\
\hline MFD & Monetary and Financial Systems Department, IMF \\
\hline ML & Money Laundering \\
\hline NCCT & Noncooperative Countries or Territories \\
\hline PCR & Proceeds of Crime (Border Currency Report Form) Regulations 2004 \\
\hline POCA & Proceeds of Crime Act 2003 \\
\hline ROSC & Report on the Observance of Standards and Codes \\
\hline SCR & United Nations Security Council Resolution \\
\hline TCA & Trustee Companies Act $1981-82$ \\
\hline UNSCRA & United Nations (Security Council Resolutions) Act 2003 \\
\hline
\end{tabular}




\title{
I. Assessment Of Observance Of The Basel Core Principles For Effective BANKING SUPERVISION
}

\author{
A. Overview
}

\section{General}

1. This assessment of the Cook Islands' current state of compliance with the Basel Core Principles for Effective Banking Supervision was conducted as part of the IMF Module 2 Offshore Financial Center (OFC) assessment program. This report provides a key input for the development of an action plan to move toward full compliance with the Core Principles. The assessors were Desiree Cherebin and Joel Shapiro, banking supervision consultants.

\section{Information and methodology used for assessment}

2. The assessment followed the core principle assessment methodology approved by the Basel Committee and was based on extensive discussions with the recently established Financial Supervisory Commission (FSC), primarily the recently appointed Commissioner. The mission reviewed the core principle self-assessment undertaken by the FSC immediately preceding this assessment. The mission held meetings with the Prime Minister, representatives of the Board of Directors of the FSC, officials of the Financial Intelligence Unit (FIU), and senior officers of the three domestic banks and one offshore bank. Discussions were also held with representatives of two audit firms, the Trust Companies Association, and the management of two trust companies offering offshore financial services. The mission also reviewed the Banking Act 2003 (BA) and three prudential statements issued under this statute in February 2004, the Financial Supervisory Commission Act 2003 (FSA), the Financial Transactions Reporting Act 2003 (FTRA), and regulations issued in February 2004, as well as other laws relevant to the operations of financial institutions licensed by the FSC. With the exception of one on-site examination report of the local domestic bank, no prudential information exists on any licensed financial institution, as the FSC has yet to implement supervisory policies and procedures.

\section{Institutional and macroprudential setting, market structure overview}

3. The Cook Islands is a small offshore center by international standards, but the sector makes a relatively significant contribution to government revenues and to GDP. Registration and license fees represent about 4 percent of government revenues, and industry estimates put the total contribution of the offshore sector in the range of 8 percent of GDP. Actually, the contribution of the offshore sector relative to GDP may have peaked with the establishment of a legal framework that requires the offshore sector to have a physical presence in the Cook Islands, and to be subject to a vigorous bank supervision regimen similar to traditional commercial banks, as some offshore institutions have indicated they do not intend to apply for a new license to conduct a banking business. 
4. In June 2000, the Cook Islands were placed on the Financial Action Task Force (FATF) list of non-cooperative countries and territories based on the absence of effective supervision of the offshore sector, the lack of an adequate infrastructure to combat money laundering, and excessive secrecy provisions. The government made some early progress in addressing the FATF's concerns, with the impetus fueled by the possibility of additional countermeasures by the FATF. More recently, the Government has refocused on initiatives to upgrade its financial sector supervision and anti-money laundering infrastructure in its efforts to be removed from the FATF "blacklist," which is a high priority for government.

5. As part of this effort, in May 2003 the Government of the Cook Islands enacted a suite of legislation to establish a sole regulator of the financial sector and strengthen its supervision. The FSC, which is the regulator, is empowered, inter alia, to license, regulate, and supervise the business of banking. One effect of the legislation is to require offshore banks to have a tangible physical presence in the Cook Islands (the "mind and matter" principle), transparent financial statements, and adequate records prepared in accordance with consistent accounting systems. All banks will be subject to a more vigorous and comprehensive regulatory process, including on-site examinations and supervision of their activities on a consolidated basis. The effect of the legislation and the supervisory processes to be implemented by the FSC may be to discourage some offshore entities from maintaining their operations in the Islands due to the cost of regulation, issues of transparency, the extent of their banking business and other factors.

6. The FSC was established in June 2003 shortly following enactment of the new legislation, and the first Commissioner was appointed in September 2003. With the exception of a Deputy Commissioner, the agency is fully staffed. The FSC is currently in the initial stages of developing systems and procedures for reviewing licensing applications. No prudential data or other supervisory information on licensees has yet been collected, with the first to be filed by licensees in connection with their application for a license under the new legislation. The FSC has not yet developed prudential returns, procedural manuals or other supervisory tools, nor developed a training program for staff. Creation of the FSC is at a start-up stage in every sense of the word, and the Commissioner's mettle as a supervisor and administrator clearly will be tested.

7. The domestic banking system is comprised of branches of major Australian banks (ANZ and Westpac), and the indigenous Bank of the Cook Islands (BCI). The latter is the result of the merger, in 2001, of the government-owned Cook Islands Development Bank and the Post Office Savings Bank. While the bank will continue to be a stand-alone institution competing against the two Australian banks, it will no longer engage in development lending. The development lending and problem loan portfolios will be transferred to companies owned by the Cook Islands Government Property Corporation.

8. The offshore financial center (OFC) was established in 1981 through the enactment of several laws which provided exemption from all forms of tax as a major inducement for all registered offshore entities There are currently sixteen international banks licensed in the Cook Islands, which were granted offshore banking licenses under the Offshore Banking 
Act 1981, which was repealed with the Banking Act 2003. In addition, the Island hosts some 800 international companies, and six trust companies that administer 2,100 international trusts. The trust companies act as representatives of some of the offshore banks. There are approximately 20 offshore insurance companies as well.

9. The primary business of the domestic banks operating in the Cook Islands is traditional deposit taking and lending. Current data on total deposits and loans was not available from the FSC during the mission, but based on information provided by the three banks at meetings held with them, it is estimated that total assets in the domestic system aggregate approximately \$NZ 180 million, of which roughly \$NZ 150 million represents loans to commercial enterprises and consumers.

\section{General preconditions for effective banking supervision}

10. Prior to enactment of the Financial Supervisory Commission Act, there was in practice no meaningful oversight and supervision of the financial sector. The Monetary Board, the predecessor to the FSC, had long ceased to function as the regulator of the domestic banks, while the Offshore Financial Services Commission viewed its principal role relative to the offshore community as a collector of license and registration fees.

11. The inadequate legal framework and the low level of resources devoted to bank supervision reinforced the conventional view that the banking system, especially offshore institutions, had free reign. There were no meaningful legal requirements pertaining to transparency, accounting standards, corporate governance or safe and sound banking practice. There was no active on-site/off-site supervision program.

12. The new legal framework represents an important first step in correcting these deficiencies, as they are all addressed in the new set of laws. The framework empowers the FSC to license, supervise and regulate the financial sector. It also provides it with enforcement authority in the event of noncompliance with the law, and to cooperate with foreign supervisors where necessary for implementation of comprehensive supervision on a consolidated basis. The second and more difficult task is implementation of these laws, and creating the appropriate supervisory infrastructure, and that is the challenge that lies ahead.

13. In addition, two specific areas not covered adequately in existing legislation must be confronted. One is that the legal framework must be strengthened for resolving problem banks, including development of procedures for receivership and liquidation. The other issue is that of a public safety net. For now, the issue revolves principally around the government's approach to rescuing depositors at BCI in the event of a financial crisis. 


\section{B. Detailed Assessment}

\section{Table 1. Detailed Assessment of Compliance of the Basel Core Principles}

\begin{tabular}{|c|c|}
\hline Principle 1. & $\begin{array}{l}\text { Objectives, autonomy, powers, and resources } \\
\text { An effective system of banking supervision will have clear responsibilities and objectives for } \\
\text { each agency involved in the supervision of banks. Each such agency should possess } \\
\text { operational independence and adequate resources. A suitable legal framework for banking } \\
\text { supervision is also necessary, including provisions relating to authorization of banking } \\
\text { establishments and their ongoing supervision; powers to address compliance with laws as } \\
\text { well as safety and soundness concerns; and legal protection for supervisors. Arrangements } \\
\text { for sharing information between supervisors and protecting the confidentiality of such } \\
\text { information should be in place. }\end{array}$ \\
\hline Principle 1(1). & $\begin{array}{l}\text { An effective system of banking supervision will have clear responsibilities and objectives for } \\
\text { each agency involved in the supervision of banks. }\end{array}$ \\
\hline & 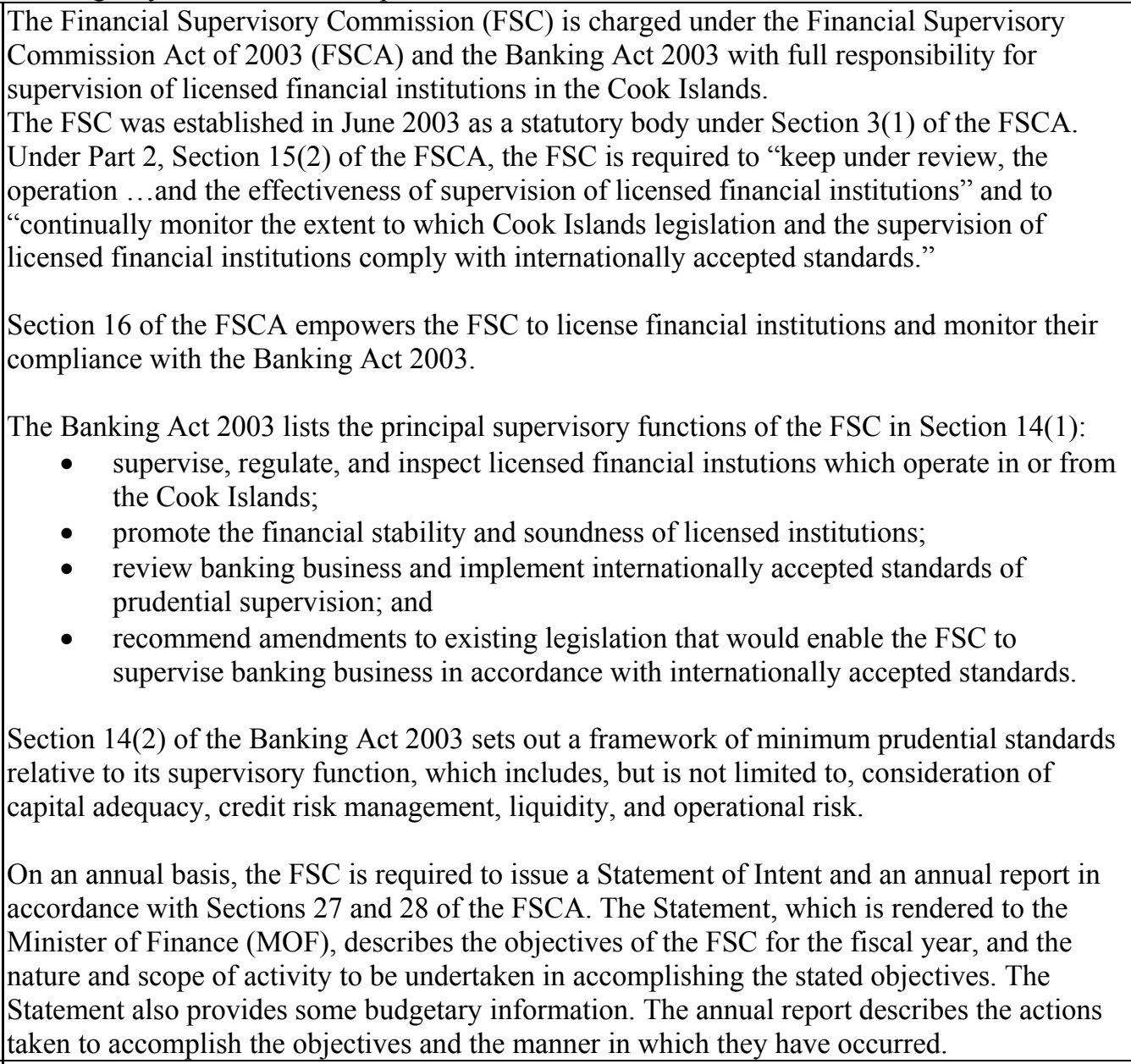 \\
\hline Assessment & Largely compliant. \\
\hline Comments & $\begin{array}{l}\text { Provisions of law relating to the orderly resolution of a problem bank are not addressed fully in } \\
\text { the FSCA, the Banking Act 2003, or other attendant legislation in the First Schedule of the } \\
\text { FSCA. Section } 17 \text { of the Banking Act } 2003 \text { empowers the FSC to take enforcement action } \\
\text { against a licensed institution in the event it is or is likely to become insolvent Such action may }\end{array}$ \\
\hline
\end{tabular}




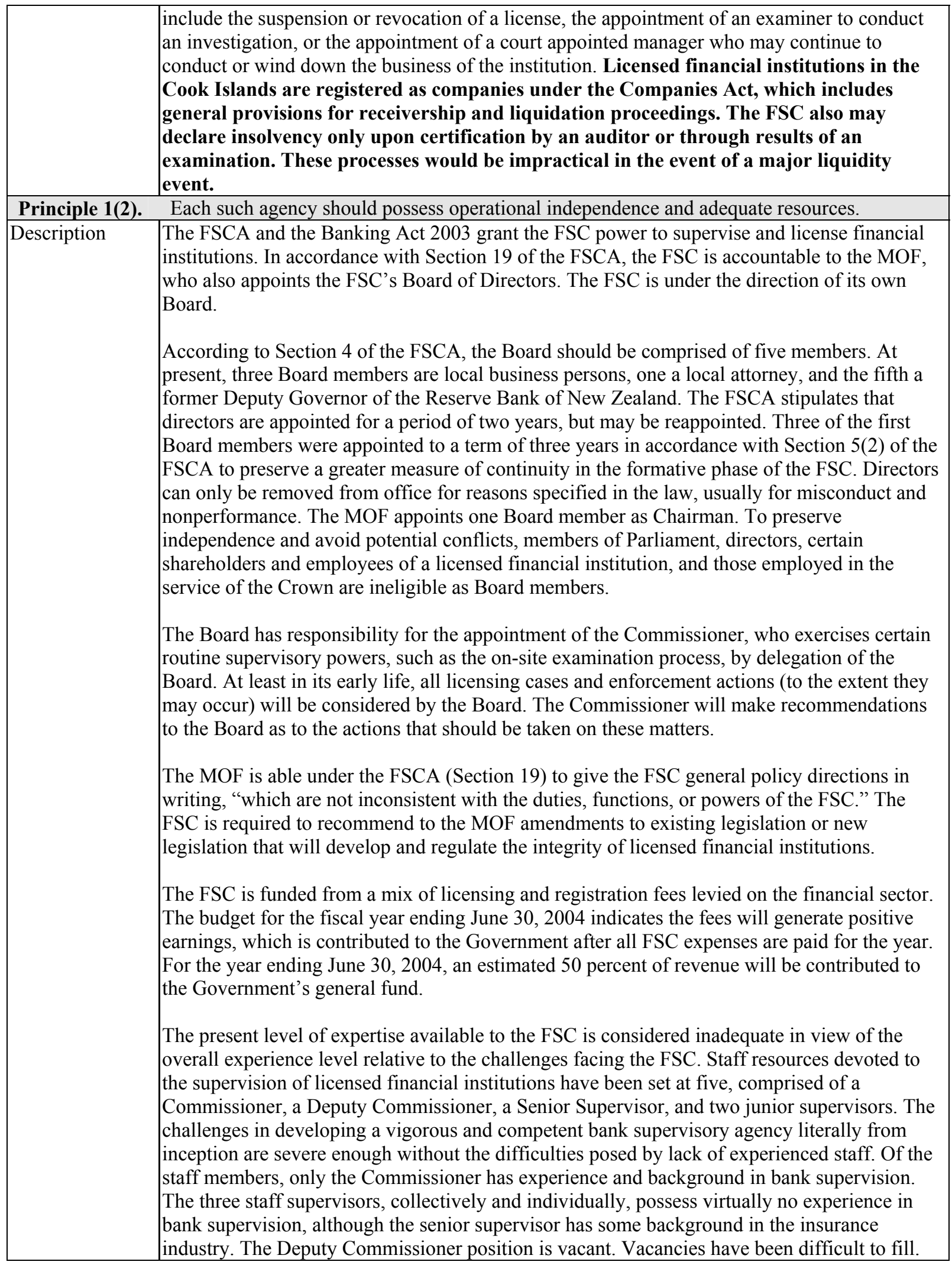




\begin{tabular}{|c|c|}
\hline & $\begin{array}{l}\text { Few residents currently meet education and experience requirements, so that senior staff } \\
\text { vacancies are being filled by expatriates on a contract basis. The Commissioner is an expatriate } \\
\text { appointed for a two-year period that commenced in September } 2003 \text {. The recently appointed } \\
\text { Senior Supervisor is an expatriate working on a contract basis, and the Deputy Commissioner } \\
\text { also is likely to be an expatriate. } \\
\text { Remuneration packages are comparable within the local market for entry-level positions, but } \\
\text { the FSC has been forced to increase the incentives to attract candidates from outside the Cook } \\
\text { Islands to fill senior positions. }\end{array}$ \\
\hline Assessment & Materially noncompliant. \\
\hline & 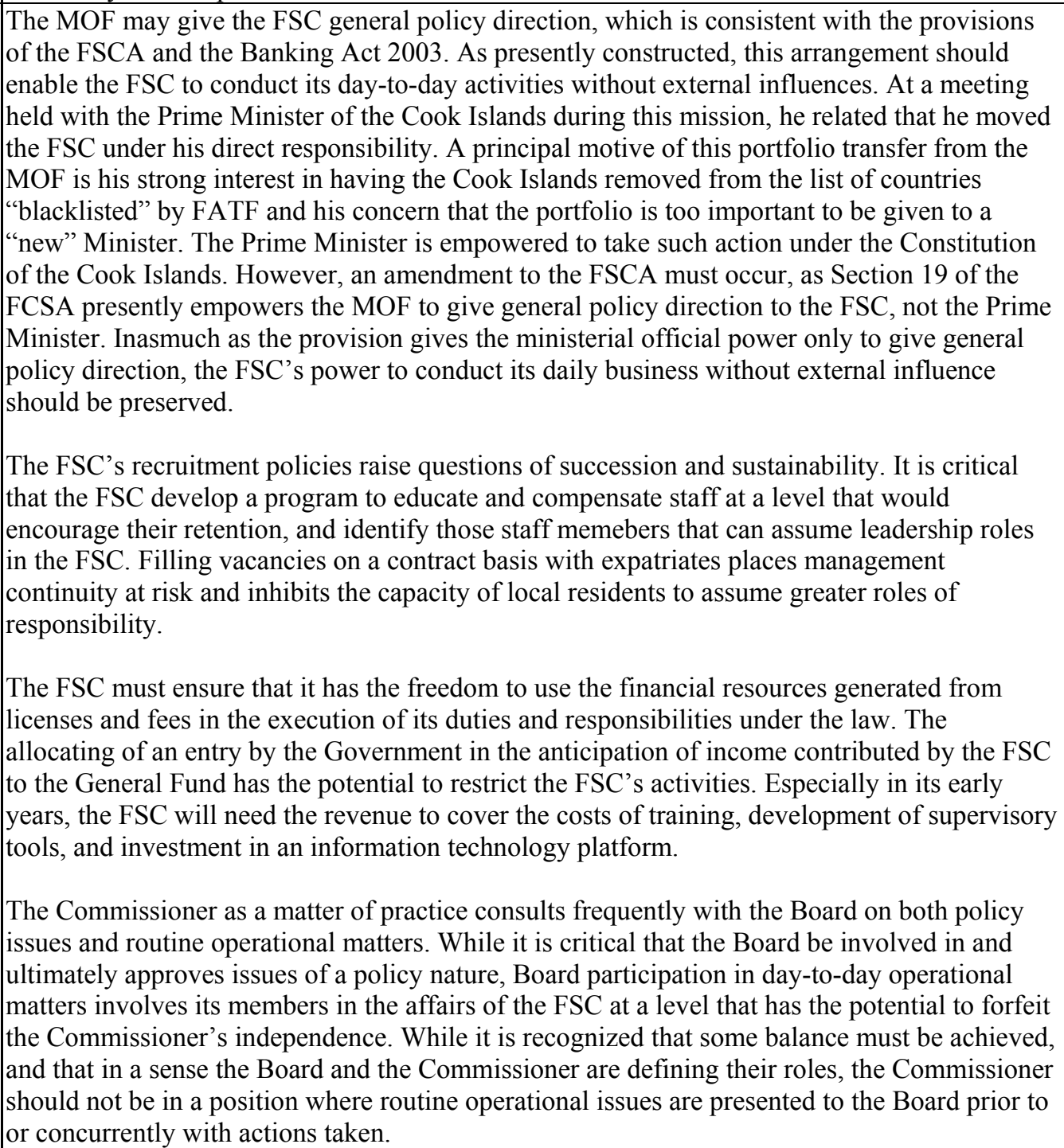 \\
\hline Principle 1(3). & $\begin{array}{l}\text { A suitable legal framework for banking supervision is also necessary, including provisions } \\
\text { relating to the authorization of banking establishments and their ongoing supervision. }\end{array}$ \\
\hline Description & $\begin{array}{l}\text { Central to the legal framework of banking supervision in the Cook Islands is the FSC, which } \\
\text { was established by the FSCA. Sections } 15 \text { and } 16 \text { of the FSCA clearly identify the FSC as the } \\
\text { authority for granting and withdrawing banking licenses and for administering and monitoring } \\
\text { compliance with the Banking Act } 2003 \text {. Section } 14 \text { of the Banking Act } 2003 \text { establishes the } \\
\text { FSC's supervision and enforcement powers. Section } 14 \text { of the Banking Act } 2003 \text { also enables }\end{array}$ \\
\hline
\end{tabular}




\begin{tabular}{|c|c|}
\hline & $\begin{array}{l}\text { the FSC to publish prudential statements in its capacity to supervise, license, and obtain } \\
\text { information, reports, or other documents from banks. } \\
\text { Section } 3 \text { of the Banking Act } 2003 \text { specifies that no entity can carry on a banking business in } \\
\text { or from the Cook Islands unless licensed by the FSC. }\end{array}$ \\
\hline Assessment & Compliant. \\
\hline Comments & $\begin{array}{l}\text { Together, the FSCA, the Banking Act 2003, and the FSC's power to issue prudential } \\
\text { statements provide the agency with a framework for the licensing and ongoing supervision of } \\
\text { entities conducting a banking business in the Cook Islands. Since the Commissioner's } \\
\text { appointment in September 2003, three comprehensive prudential statements have been issued } \\
\text { by the FSC. The statements address the process for applying for a license, capital adequacy } \\
\text { guidelines and guidelines covering the classification of assets, loan loss reserves and assets } \\
\text { placed on nonaccrual. }\end{array}$ \\
\hline Principle 1(4). & $\begin{array}{l}\text { A suitable legal framework for banking supervision is also necessary, including powers to } \\
\text { address compliance with laws as well as safety and soundness concerns. }\end{array}$ \\
\hline Description & $\begin{array}{l}\text { Part } 2 \text { of the FSCA articulates the FSC's duties, functions and powers. In this connection, } \\
\text { Section } 15 \text { enables the FSC to review, enact or amend legislation related to the supervision of } \\
\text { licensed financial institutions. Section } 16 \text { empowers the FSC to license these institutions, and } \\
\text { Section } 18 \text { provides the FSC with the power to conduct on-site examinations and collect } \\
\text { information it requires to ensure compliance with all legal requirements. } \\
\text { The FSCA also empowers the FSC to enforce the Banking Act } 2003 \text {, which stipulates the } \\
\text { FSC's supervision and enforcement authority under Part } 3 \text {. In accordance with Section } 14 \text { of } \\
\text { the Banking Act } 2003 \text {, the FSC must implement internationally accepted standards for the } \\
\text { prudential supervision of banking business, and "collect and analyze such information as may } \\
\text { be required in prudential matters relating to licensees." Under Section } 15 \text {, the FSC may } \\
\text { conduct compliance inspections. } \\
\text { There are also additional powers to investigate (Section } 17 \text { ) where more serious concerns arise. } \\
\text { The Banking Act } 2003 \text { creates a number of formal offenses and penalties for breaches of law } \\
\text { and noncompliance. It also provides regulatory tools enabling the FSC to intervene when } \\
\text { particular concerns arise. These tools range from the issuance of a specific directive against a } \\
\text { licensed financial institution to revocation of the license. However, they do not describe a full } \\
\text { ladder of enforcement actions, nor do they empower the FSC to impose fines or civil money } \\
\text { penalties. } \\
\text { In carrying out its bank supervision authority, the Banking Act } 2003 \text { lists certain minimum } \\
\text { criteria the FSC must consider. These criteria include capital adequacy, asset concentration and } \\
\text { risk exposure, liquidity, asset quality, internal controls, and risk management and accounting } \\
\text { systems. }\end{array}$ \\
\hline Assessment & Compliant. \\
\hline Comments & \\
\hline Principle 1(5). & $\begin{array}{l}\text { A suitable legal framework for banking supervision is also necessary, including legal } \\
\text { protection for supervisors. }\end{array}$ \\
\hline Description & $\begin{array}{l}\text { Section } 14 \text { of the FCSA provides legal protection for the FSC's Board members, the } \\
\text { Commissioner and staff, or other persons acting under the authority of the FSC against } \\
\text { damages for acts or omissions in discharge or purported discharge in their capacity with the } \\
\text { FSC. } \\
\text { The Board has necessary means through fees generated from licensing and registration } \\
\text { activities to protect staff against the costs of defending their actions while discharging their } \\
\text { duties. }\end{array}$ \\
\hline
\end{tabular}




\begin{tabular}{|c|c|}
\hline & $\begin{array}{l}\text { The FSC's Board of Directors approved utilization of agency funds in defense of staff or } \\
\text { FSCA actions or discharge of duties at the Board meeting held February } 12,2004 .\end{array}$ \\
\hline Assessment & Compliant. \\
\hline \multicolumn{2}{|l|}{ Comments } \\
\hline Principle 1(6). & $\begin{array}{l}\text { Arrangements for sharing information between supervisors and protecting the confidentiality } \\
\text { of such information should be in place. }\end{array}$ \\
\hline Description & $\begin{array}{l}\text { The FSC is the sole domestic supervisor with responsibilities for the safety and soundness of } \\
\text { licensed financial institutions. } \\
\text { Section 23(1) of the FCSA protects the confidentiality of the affairs of a licensed financial } \\
\text { institution, making disclosure a punishable offense. Certain exceptions are listed in Section } \\
23 \text { (2), including disclosures lawfully required or permitted by Cook Islands law or for the } \\
\text { purpose of criminal proceedings. Under these exceptions, the Financial Intelligence Unit (FIU) } \\
\text { in the Cook Islands is able to collect information it requires in carrying out its responsibilities. } \\
\text { Provisions of the Financial Transactions Reporting Act } 2003 \text { also permit the exchange of } \\
\text { information between the FSC and the FIU. } \\
\text { The FSCA (Section 23) permits disclosure of information on licensed financial institutions to } \\
\text { overseas regulatory authorities, including for purposes of conducting civil or administrative } \\
\text { investigations and proceedings to enforce laws, regulation and rules administered to that } \\
\text { authority. Under the Banking Act } 2003 \text {, Section } 46(2) \text {, disclosure of information by the FSC to } \\
\text { a foreign supervisory authority is permitted. In addition, Section } 16 \text { of the Banking Act } 2003 \\
\text { permits a foreign supervisory authority to participate in a compliance inspection undertaken by } \\
\text { the FSC. }\end{array}$ \\
\hline Assessment & Largely compliant. \\
\hline Comments & $\begin{array}{l}\text { The Confidentiality and Disclosure provisions of the Banking Act } 2003 \text { are inconsistent and } \\
\text { sometimes duplicative with those contained in the FSCA. Thus, while Section 20(1) of the } \\
\text { FSCA broadly authorizes the FSC to require bank employees and others not affiliated with a } \\
\text { licensee to provide it with information that it needs to carry out its regulatory functions, the } \\
\text { confidentiality provisions of the Banking Act } 2003 \text { (Section } 47(2) \text { ) applicable to such persons } \\
\text { prohibit the disclosure of "protected information" to the FSC except in connection with the } \\
\text { investigation or prosecution of a criminal case. The standards under which confidential } \\
\text { information may be provided to foreign regulatory authorities are similar but not identical } \\
\text { under the two statutes. Sections } 23(1) \text { of the FSCA and } 46(2) \text { (g) of the Banking Act } 2003 \text {; and } \\
\text { Sections } 20(3) \text { of the FSCA and } 47 \text { of the Banking Act are those that differ in this regard. The } \\
\text { disclosure of confidential information by FSC directors and staff is made an offense under both } \\
\text { statutes, though the penalties are different. The existence of two different statutes separately } \\
\text { criminalizing similar behavior is a potential problem. The Confidentiality and Disclosure } \\
\text { provisions of the two statutes should be harmonized. Issues relating to protection of } \\
\text { information in the hands of the FSC and its agents, and cooperation with foreign authorities } \\
\text { should be dealt with only in the FSCA. Finally, confidentiality provisions in the Banking Act } \\
\text { 2003, if determined to be necessary, should be limited to provisions applicable to licensees and } \\
\text { their agents, with disclosure provisions that do not block the FSC from obtaining information } \\
\text { that it needs for supervisory purposes or to cooperate with foreign authorities in accordance } \\
\text { with international standards. } \\
\text { While provisions of the FSCA and the Banking Act } 2003 \text { enable the FSC to disclose } \\
\text { information to the FIU and foreign supervisory authorities, no formal processes have been } \\
\text { established to date governing the exchange of such information. The FSC has opened } \\
\text { discussions with the FIU and the Australian Prudential Regulatory Authority (APRA) in } \\
\text { pursuit of formulating a process. }\end{array}$ \\
\hline & \\
\hline
\end{tabular}




\begin{tabular}{|c|c|}
\hline & $\begin{array}{l}\text { The permissible activities of institutions that are licensed and subject to supervision as banks } \\
\text { must be clearly defined, and the use of the word "bank" in names should be controlled as far } \\
\text { as possible. }\end{array}$ \\
\hline Description & $\begin{array}{l}\text { Section } 2 \text { of the Banking Act } 2003 \text { defines a "banking business" to mean "the business of } \\
\text { receiving funds through the acceptance of money deposits... or any similar operation through } \\
\text { the sale or placement of bonds, certificates, notes or other securities, and the use of such } \\
\text { funds... for loans or investment for the account and the risk of the person (licensed financial } \\
\text { institution) doing such business." This provision of the Banking Act } 2003 \text { also states that other } \\
\text { activities may be prescribed by regulation as constituting customary banking practice that an } \\
\text { institution may be authorized to conduct. } \\
\text { Section } 3 \text { of the Banking Act } 2003 \text { restricts carrying on a banking business to institutions } \\
\text { licensed by the FSC. } \\
\text { According to Section } 52 \text { of the Banking Act } 2003 \text {, no entity other than a licensed financial } \\
\text { institution carrying on business in the Cook Islands may use any name, description or title } \\
\text { which connotes the term bank or a derivative of the word bank in any language, or any other } \\
\text { word that indicates that the entity is conducting a banking business, without the prior approval } \\
\text { of the FSC. As a practical matter, the FSC may authorize the use of the name bank for entities } \\
\text { other than licensed institutions. } \\
\text { The penalty, on conviction, for contravention of the provisions of section } 3 \text { is a fine not } \\
\text { exceeding \$NZ } 50,000 \text { or imprisonment for a term not exceeding } 3 \text { years, or both in the case of } \\
\text { an individual, or in any other case a fine not exceeding } \$ N Z 250,000 \text {. } \\
\text { The penalty, on conviction, for contravention of the provisions of section } 52 \text { is a fine not } \\
\text { exceeding } \$ N Z 50,000 \text { or imprisonment for a term not exceeding } 2 \text { years or both in the case of } \\
\text { an individual, or a fine not exceeding \$NZ } 250,000 \text { in the case of a body corporate. }\end{array}$ \\
\hline Assessment & Largely compliant. \\
\hline Comments & $\begin{array}{l}\text { While there is a provision of the Banking Act } 2003 \text { enabling the FSC to prescribe additional } \\
\text { activities or products as customary banking practice (Section 2), the agency has not issued } \\
\text { directives or prudential regulations stipulating additional permissible activities, such as the } \\
\text { conduct of foreign exchange services. } \\
\text { The FSC needs to be mindful that Bank of the Cook Islands Holding Corporation must have } \\
\text { approval of the FSC to continue to use the word "bank" in its name subsequent to } \\
\text { June } 4,2004, \text { which is the date on which the Corporation's banking license expires. }\end{array}$ \\
\hline Principle 3. & $\begin{array}{l}\text { Licensing criteria } \\
\text { The licensing authority must have the right to set criteria and reject applications for } \\
\text { establishments that do not meet the standards set. The licensing process, at a minimum, } \\
\text { should consist of an assessment of the banking organization's ownership structure, directors } \\
\text { and senior management, its operating plan and internal controls, and its projected financial } \\
\text { condition, including its capital base; where the proposed owner or parent organization is a } \\
\text { foreign bank, the prior consent of its home country supervisor should be obtained. }\end{array}$ \\
\hline Description & $\begin{array}{l}\text { Pursuant to Section 16(1) (a) of the FSCA, the FSC is empowered to license financial } \\
\text { institutions, monitor their compliance with other laws and regulations and any conditions } \\
\text { imposed by the FSC in the granting of the license. Section } 3 \text { of the Banking Act } 2003 \text { states } \\
\text { that an entity may conduct banking business in or from the Cook Islands only if the entity is } \\
\text { licensed under that Act. The FSC is authorized to examine the books and records of an entity } \\
\text { that it believes is conducting a banking business in contravention of the licensing provisions of } \\
\text { the Banking Act } 2003 \text {. Conducting an unlicensed banking business is a punishable offense. }\end{array}$ \\
\hline
\end{tabular}


The FSC may grant three classes of banking licenses in accordance with the licensing provisions of the Banking Act 2003. One is a domestic banking license authorizing an institution to conduct a domestic banking business. A second license, an international banking license, permits holders to carry on an international banking business in or from the Cook Islands. The third license is a restricted international banking license, which authorizes the licensee to carry on an international banking business as specified in the license. When the Banking Act 2003 was enacted in May 2003, entities operating a banking business under the Banking Act 1969 were granted a domestic banking license. The Bank of the Cook Islands was deemed to have a domestic banking license. Those institutions operating a banking business under the Offshore Banking Act 1981-82 (offshore and shell banking companies) were granted an international banking license. Foreign banks - those with branches in the Cook Islandswere permitted to hold a domestic banking license. There are no institutions holding a restricted international banking license at present. All licenses currently held by institutions to conduct a banking business under the Banking Act 2003 are temporary in nature. Each of these institutions must submit license applications to the FSC by March 1, 2004, allowing 90 days to process before the June 1, 2004 deadline.

The Banking Act 2003 lists specific criteria that an applicant must fulfill in order to be granted a license to conduct a banking business. These include, but are not limited to:

- the ownership structure, reputation, financial capacity, and financial history of the applicant are satisfactory;

- each director, manager, and associate of the applicant is a fit and proper person;

- the risk management, accounting, and internal control systems are satisfactory; and

- the capital structure of the applicant is adequate and a minimum capital base of \$NZ 2 million has been fully paid.

There are specific criteria for foreign banks as well. In addition to the criteria listed above, they include, but are not limited to, the following:

- the foreign bank is subject to comprehensive supervision and regulation on a consolidated basis by the home country supervisor; and

- the home country supervisor has provided written confirmation that it has no objection to the foreign bank carrying on business in the Cook Islands, and that it is willing to cooperate in the supervision of the foreign bank.

The FSC has the authority to revoke or suspend a license in the event there has been a breach in the terms or conditions under which a license was granted or the FSC was furnished with false, inaccurate or misleading information. Applications may be rejected if criteria are not fulfilled or information is inadequate.

Section 23 of the Banking Act 2003 requires each licensee, with the exception of those with a restricted license, to maintain a physical presence in the Cook Islands. The physical presence is defined as having both "mind and management" operating the institution from the Cook Islands. In this connection, a licensee must conduct a banking business from its designated premises, maintain operating records, including financial statements relating to its banking business, and have at least one employee who is knowledgeable on a day-to-day basis of the institution's banking business. This provision is directed specifically at the institutions that plan to apply for an international banking license and operated previously under the Offshore Banking Act 1981-82.

The FSC has issued Prudential Statement No. 1-2004, "Bank Licensing Requirements, Policies and Procedures," to provide for the standardization of written applications and minimum information requirements for the licensing of a bank and to promote transparency in licensing 


\begin{tabular}{|c|c|}
\hline & 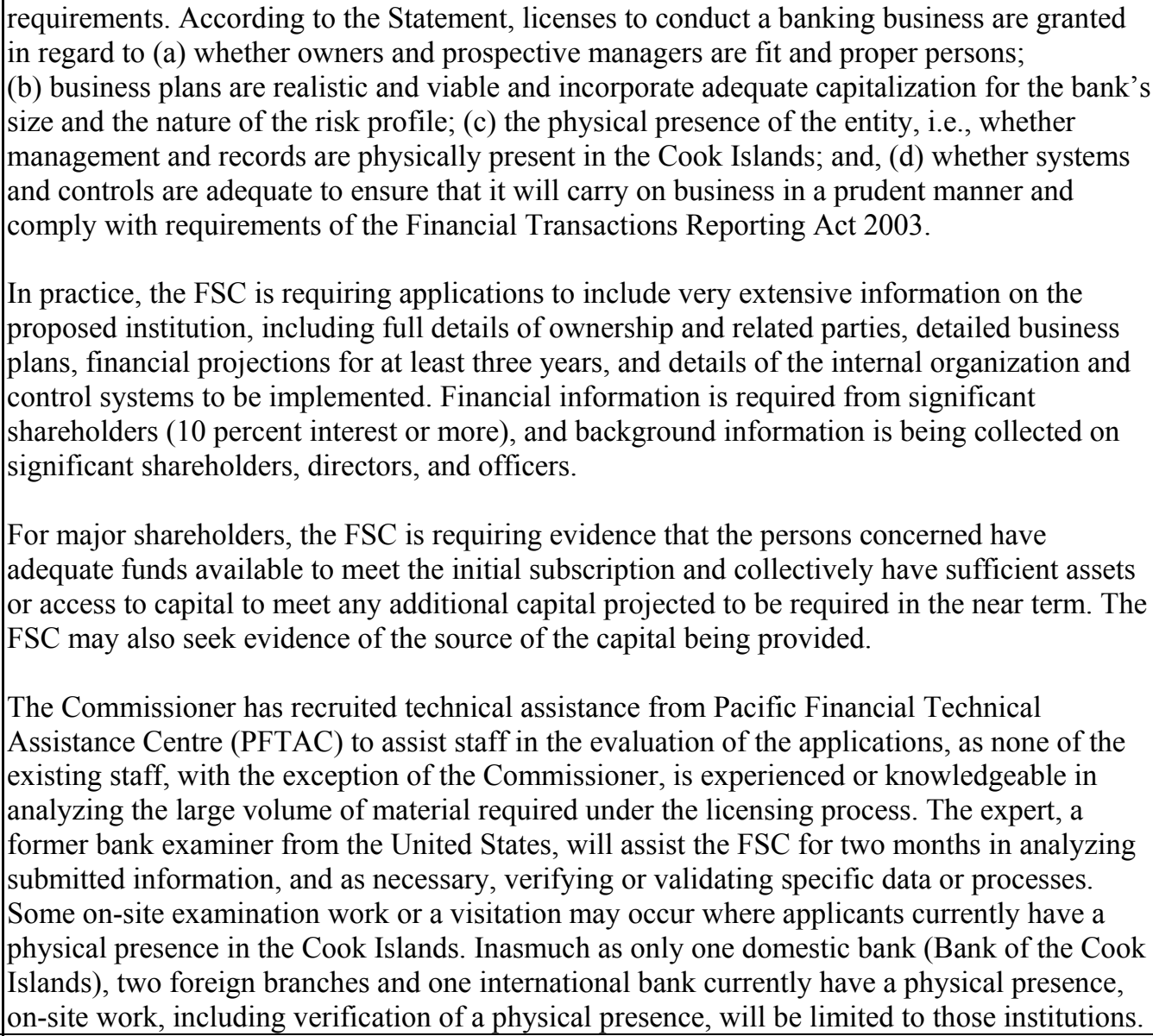 \\
\hline Assessment & Largely compliant. \\
\hline Comments & $\begin{array}{l}\text { The FSC will benefit from a sound system of laws governing administration of the licensing } \\
\text { function, and the establishment of a policy statement to guide prospective applicants in the } \\
\text { licensing process. However, the FSC's licensing processes and procedures will not be tested } \\
\text { until applicants file their applications at the beginning of March } 2004 \text {. } \\
\text { In connection with enactment of the FSCA and the Banking Act } 2003 \text {, all entities licensed } \\
\text { under the Banking Act } 1969 \text { and the Offshore Banking Act } 1981-82 \text { were granted either a } \\
\text { domestic or an international license to conduct a banking business. These licenses in a sense } \\
\text { are temporary, as each licensee is required to apply for a new license by March } 1,2004 \text {. These } \\
\text { applications will be evaluated and new licenses awarded to successful applicants } \\
\text { by June } 1,2004 \text {. } \\
\text { Much anticipated is the number and quality of applications that will be submitted by the } \\
\text { international banks-the offshore community of banks operating formerly under the Offshore } \\
\text { Banking Act } 1981-82 \text {. Of } 16 \text { such institutions licensed at present under the Banking Act } 2003 \text {, } \\
\text { only eight have indicated their intention to seek a new license. An important initiative of the } \\
\text { FSC subsequent to the evaluation and awarding of licenses will be verifying the physical } \\
\text { presence requirements for the international banks that may be successful in acquiring an } \\
\text { international banking license. As part of this exercise, the FSC should take the opportunity to } \\
\text { review its interpretation of a physical presence, based on approaches taken by these } \\
\text { international licensees, and issue a prudential statement reflecting its view of "best practices." }\end{array}$ \\
\hline
\end{tabular}




\begin{tabular}{|c|c|}
\hline & $\begin{array}{l}\text { Another important initiative pertaining to these institutions-and to all licensed institutions in } \\
\text { general-will be an ongoing program of regular examination and review, including monitoring } \\
\text { implementation of business and strategic plans, and gauging whether licensing commitments } \\
\text { are being met. No aspects of this supervisory program have yet been established by the FSC. } \\
\text { In light of the nature of the business and organizational structure of the international banks, the } \\
\text { FSC must commence a communication process to facilitate the exchange of supervisory } \\
\text { information with host country supervisors at an early date. } \\
\text { There also remains outstanding the issue of a planned approach to entities that should be } \\
\text { licensed as conducting a banking business but have been able to operate in an unregulated } \\
\text { fashion to date. One aspect of this issue is to ensure that the eight institutions who have } \\
\text { indicated that they do not intend to apply for a new license have surrendered their license and } \\
\text { have wound down their banking business. The other aspect is to identify in some way those } \\
\text { entities that may have escaped regulation. One approach is to publish a comprehensive list } \\
\text { readily accessible to the public of all institutions licensed to conduct a banking business, } \\
\text { indicating that any other such institutions are operating in contravention of existing banking } \\
\text { law. In addition, the FSC should publish notices when it comes to its attention that an } \\
\text { institution is conducting a banking business without a license, and where practicable, move } \\
\text { against the institution in accordance with the law. }\end{array}$ \\
\hline Principle 4. & $\begin{array}{l}\text { Ownership } \\
\text { Banking supervisors must have the authority to review and reject any proposals to transfer } \\
\text { significant ownership or controlling interests in existing banks to other parties. }\end{array}$ \\
\hline Description & $\begin{array}{l}\text { Section } 2(2) \text { of the Banking Act } 2003 \text { defines a significant ownership interest in a company as } \\
\text { a situation where the entity has a legal or equitable interest, either directly or indirectly, that } \\
\text { enables the entity to control } 10 \text { percent or more of the company's voting stock, or entitles the } \\
\text { entity to a share of } 10 \text { percent or more of the dividends declared and paid, or is entitled to a } \\
\text { share of } 10 \text { percent or more in the distribution of surplus assets of the company. } \\
\text { The Banking Act } 2003 \text {, under Section } 35 \text {, empowers the FSC to approve the sale, transfer or } \\
\text { disposition in any other manner of a significant interest in a licensed financial institution prior } \\
\text { to the transaction. Prudential Statement } 1-2004 \text { states that significant changes in ownership } \\
\text { must be reported prior to their occurrence, and that licensing requirements would be } \\
\text { considered in any such change of control. The FSC's approval must be in writing, with specific } \\
\text { terms and conditions articulated in the approval. }\end{array}$ \\
\hline Assessment & Largely compliant. \\
\hline Comments & $\begin{array}{l}\text { There is no standardized medium through which changes in significant ownership can be } \\
\text { reported. To facilitate the reporting of such transactions, the FSC may want to consider the } \\
\text { development of a standardized form to ensure communication of essential information, such as } \\
\text { the number of shares in question, the value of the sale or transfer, mode, source and terms of } \\
\text { financing, whether the shares have been used as collateral, and name of the financing } \\
\text { institution. } \\
\text { New significant owners will otherwise be subject to all licensing criteria and application } \\
\text { requirements. }\end{array}$ \\
\hline Principle 5. & $\begin{array}{l}\text { Investment criteria } \\
\text { Banking supervisors must have the authority to establish criteria for reviewing major } \\
\text { acquisitions or investments by a bank and ensuring that corporate affiliations or structures do } \\
\text { not expose the bank to undue risks or hinder effective supervision. }\end{array}$ \\
\hline Description & $\begin{array}{l}\text { Section } 39 \text { of the Banking Act } 2003 \text { restricts a licensed financial institution from acquiring an } \\
\text { equity interest in a commercial, agricultural, industrial or other enterprise if the combined } \\
\text { value of the shares would exceed } 25 \text { percent of the licensee's eligible capital. Written approval } \\
\text { of the FSC must be obtained to exceed this limit. Section } 34 \text { requires the licensed financial }\end{array}$ \\
\hline
\end{tabular}




\begin{tabular}{|c|c|}
\hline & $\begin{array}{l}\text { institution to obtain the FSC's written approval prior to making an acquisition of the business } \\
\text { of another licensee or financial institution in the Cook Islands. The Banking Act } 2003 \text { lists } \\
\text { several exceptions to the exposure to capital benchmark, including shares taken for debts } \\
\text { previously contracted, acquisition or disposal of shares in a financial institution, and foreign } \\
\text { banks. }\end{array}$ \\
\hline Assessment & Largely compliant. \\
\hline Comments & $\begin{array}{l}\text { The FSC has not issued criteria for assessing individual investment proposals through a } \\
\text { Prudential Statement, and with the exception of the capital restriction, none appear in the law. } \\
\text { Moreover, the law does not distinguish between cases in which prior approval is required, and } \\
\text { cases where an after-the fact notification would be deemed to be sufficient. }\end{array}$ \\
\hline Principle 6. & $\begin{array}{l}\text { Capital adequacy } \\
\text { Banking supervisors must set minimum capital requirements for banks that reflect the risks } \\
\text { the bank undertakes, and must define the components of capital, bearing in mind its ability to } \\
\text { absorb losses. For internationally active banks, these requirements must not be less than } \\
\text { those established in the Basel Capital Accord. }\end{array}$ \\
\hline Description & 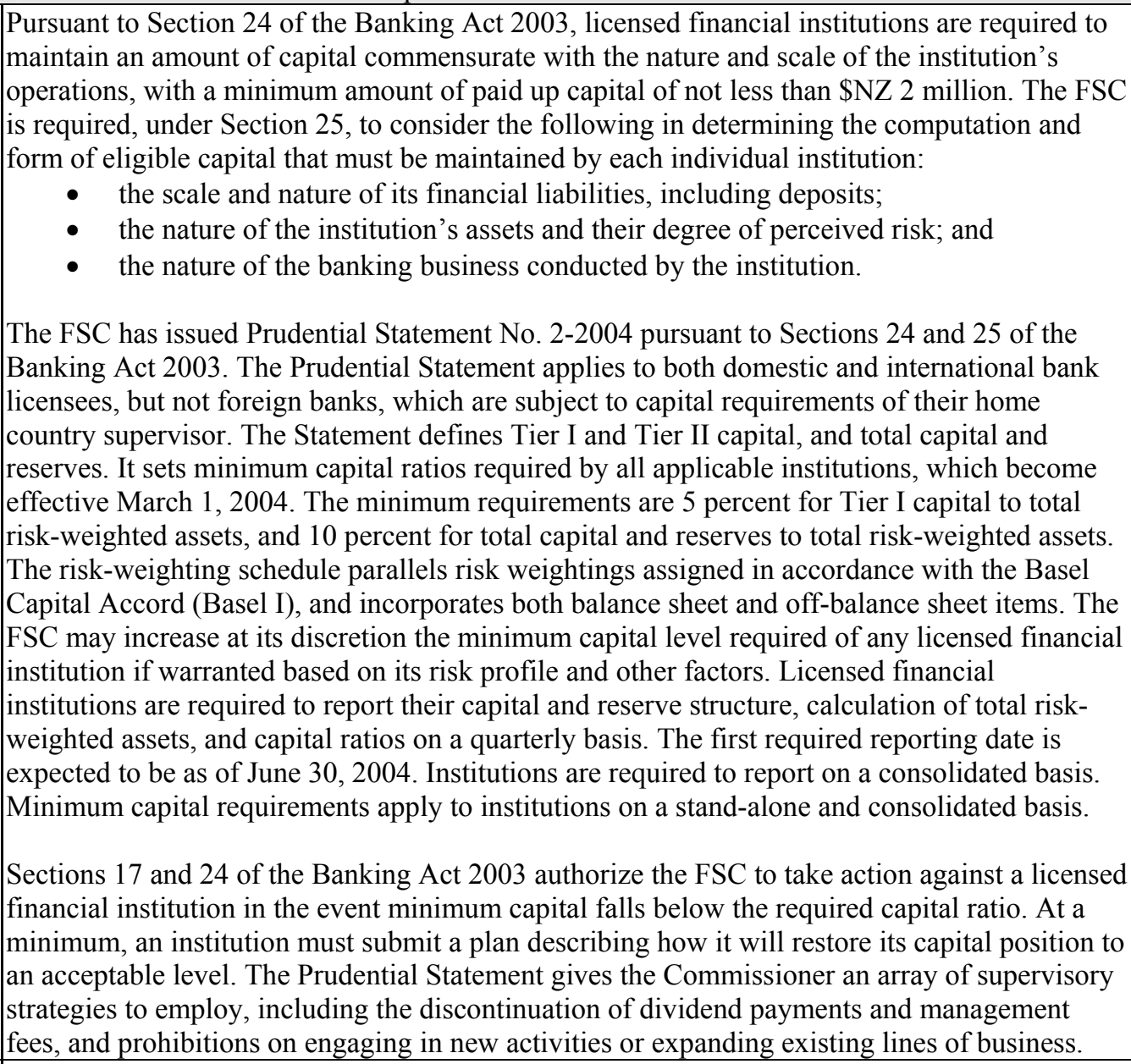 \\
\hline Assessment & Compliant. \\
\hline Comments & $\begin{array}{l}\text { When the capital requirements were introduced, no development of a specific market risk } \\
\text { calculation was made. This was based on a belief that licensed financial institutions conducting } \\
\text { a banking business in the Cook Islands undertake very little, if any, own account-trading } \\
\text { activity and so are unlikely to face material additional capital requirements for market risk. } \\
\text { Information from an on-site examination ratifies this belief for the Island's sole domestic } \\
\text { financial institution. What the international banks may do is unknown at present, and will not }\end{array}$ \\
\hline
\end{tabular}




\begin{tabular}{|c|c|}
\hline & $\begin{array}{l}\text { be known until the FSC undertakes its analysis of licensing applications and its on-site } \\
\text { examination program. The Prudential Statement should be amended to capture this information } \\
\text { in the event it is deemed necessary. } \\
\text { Definitions for certain off-balance sheet line items in the quarterly report are warranted to } \\
\text { avoid varying interpretations of what to report and to assure greater consistency in reporting. }\end{array}$ \\
\hline Principle 7. & $\begin{array}{l}\text { Credit policies } \\
\text { An essential part of any supervisory system is the independent evaluation of a bank's } \\
\text { policies, practices and procedures related to the granting of loans and making of investments } \\
\text { and the ongoing management of the loan and investment portfolios. }\end{array}$ \\
\hline Description & $\begin{array}{l}\text { Section 14(2)(e) of the Banking Act } 2003 \text { requires the FSC to evaluate the quality of a } \\
\text { licensee's assets, while Section } 15 \text { of the Banking Act } 2003 \text { and Section } 18 \text { of the FSCA allow } \\
\text { it to request from licensees any information needed to undertake its supervisory functions. } \\
\text { However, no Prudential Standard has yet been issued by the FSC relating to credit and } \\
\text { investment administration that would address a bank's credit risk management or investment } \\
\text { program. } \\
\text { Moreover, the FSC has not yet developed systems and procedures for assessing the adequacy } \\
\text { of applicants' risk management policies and procedures. Since a number of existing offshore } \\
\text { banks have indicated their intention to apply for licenses, the FSC needs to urgently implement } \\
\text { such procedures. } \\
\text { There is no reporting system in place to measure risk undertaken by licensed financial } \\
\text { institutions, and this is required prior to the June } 1,2004 \text { deadline for issuing new licenses. } \\
\text { In addition, the FSC examiners do not possess the required expertise to assess the adequacy of } \\
\text { licensees' policies and procedures for monitoring and controlling credit risk. } \\
\text { The issues pertaining to the FSC's capabilities relative to assessing a bank's credit risk } \\
\text { management policies and procedures extend well beyond this risk activity. The FSC is } \\
\text { confronted with this obstacle in virtually each risk category, such as country risk, market risk } \\
\text { and other risks, as described in Core Principles } 11,12 \text {, and } 13 \text {. } \\
\text { enhancing the FSC's supervision staff in assessing a bank's credit risk management policies } \\
\text { and practices. } \\
\text { since its establishment in July } 2003 \text {, the FSC conducted an on-site examination of one } \\
\text { understanding of the bank's management systems and controls relating to credit risk. For this } \\
\text { examination, the PFTAC Bank Supervision Adviser prepared summary notes to assist the }\end{array}$ \\
\hline & Materially noncompliant. \\
\hline Comments & $\begin{array}{l}\text { In order to effectively carry out its responsibilities specified in Section 14(2) of the Banking } \\
\text { Act 2003, the FSC may want to issue a Prudential Standard requiring banks to establish and } \\
\text { document credit and investment policies which include maintaining appropriate credit } \\
\text { administration and on-going monitoring/reporting processes, ensuring controls over } \\
\text { credit/investment risks, and establishing systems for ensuring compliance with legal provisions } \\
\text { including those relating to large exposures and group/related party transactions. } \\
\text { An on-going inspection program for the on-site review of the credit and other operations of } \\
\text { licensees also needs to be implemented by the FSC to ensure compliance with the provisions of } \\
\text { laws, regulations, and directives. }\end{array}$ \\
\hline
\end{tabular}




\begin{tabular}{|c|c|}
\hline & $\begin{array}{l}\text { includes detailed procedures for reviewing loans and other assets, and assessing risk } \\
\text { management. } \\
\text { None of the FSC's bank supervisors, all recently recruited, have any experience in bank } \\
\text { examination. The FSC, in close collaboration with PFTAC should give high priority to putting } \\
\text { together an intensive training program for its bank supervisors, which includes attendance at } \\
\text { training courses, attachments and on-the-job training. }\end{array}$ \\
\hline Principle 8. & $\begin{array}{l}\text { Loan evaluation and loan loss provisioning } \\
\text { Banking supervisors must be satisfied that banks establish and adhere to adequate policies, } \\
\text { practices and procedures for evaluating the quality of assets and the adequacy of loan loss } \\
\text { provisions and reserves. }\end{array}$ \\
\hline Description & $\begin{array}{l}\text { Section 14(2)(e) of the Banking Act } 2003 \text { requires the FSC to evaluate the adequacy of a } \\
\text { licensee's loss provisions and in February } 2004 \text { the FSC issued Prudential Statement 3-2004 } \\
\text { on "Asset Classification, Provisioning and Non Accrual of Interest." } \\
\text { Paragraphs } 4 \text { and } 5 \text { of Prudential Statement } 3-2004 \text { require the board of directors to ensure that } \\
\text { a quarterly review is carried out on all loans in excess of } 10 \text { percent of capital, the twenty } \\
\text { largest borrowers, nonaccrual loans and a sample of the remainder of the loan portfolio, to } \\
\text { facilitate the categorization of loans as nonperforming, to assure adequate provisioning and to } \\
\text { correct any problems identified. } \\
\text { Paragraph } 11 \text { of Prudential Statement } 3-2004 \text { sets out the classification categories and criteria } \\
\text { while Paragraphs } 12 \text { and } 13 \text { set out the provisioning and record-keeping requirements for loans } \\
\text { and other assets. Only loans and assets secured by cash, government guarantees and securities, } \\
\text { and FSC approved liquid and readily marketable assets are exempt from classification and } \\
\text { provisioning requirements. However, the FSC recognizes the need for Prudential Statement } 3 \text { - } \\
\text { 2004 to be amended to include classification and provisioning requirement for off-balance } \\
\text { sheet assets. } \\
\text { Under Section } 44 \text { of the Banking Act } 2003 \text {, the FSC may require licensees to submit an } \\
\text { auditor's report on the adequacy of provisions for losses. } \\
\text { The sole PFTAC-assisted on-site inspection referred to in Core Principle } 7 \text { did not include a } \\
\text { comprehensive assessment of the adequacy of the bank's loan classification and provisioning } \\
\text { process. The FSC advised the mission that a significant objective of its proposed on-site } \\
\text { inspection program would be asset evaluation and provisioning. }\end{array}$ \\
\hline Assessment & Largely compliant. \\
\hline Comments & $\begin{array}{l}\text { The Banking Act } 2003 \text { and Prudential Statement 3-2004 have established adequate regulatory } \\
\text { criteria for on-balance sheet asset classification and provisioning; however, Prudential } \\
\text { Statement 3-2004 needs to be expanded to include off-balance sheet items. } \\
\text { The newly recruited examiners have to be adequately trained to carry out asset evaluations and } \\
\text { a procedures manual is also required to assist examiners. In order to expedite this process, the } \\
\text { PFTAC Bank Supervisor Adviser has agreed to assist with arranging classroom training and } \\
\text { attachments for the examiners in the near term. }\end{array}$ \\
\hline Principle 9. & $\begin{array}{l}\text { Large exposure limits } \\
\text { Banking supervisors must be satisfied that banks have management information systems that } \\
\text { enable management to identify concentrations within the portfolio and supervisors must set } \\
\text { prudential limits to restrict bank exposures to single borrowers or groups of related } \\
\text { borrowers. }\end{array}$ \\
\hline Description & $\begin{array}{l}\text { Section } 36 \text { of the Banking Act } 2003 \text { restricts solo and group advances, including off-balance } \\
\text { sheet items, to } 25 \text { percent of capital and also defines "group" as entities under the control of a } \\
\text { person holding at least } 51 \text { percent of the voting shares of each body in the group or exercises }\end{array}$ \\
\hline
\end{tabular}




\begin{tabular}{|c|c|}
\hline & $\begin{array}{l}\text { practical control over the policies of each of the bodies in the group. } \\
\text { Advances made by a foreign bank, which is defined as "a company incorporated or } \\
\text { established, and licensed to carry on banking business, in a jurisdiction outside the Cook } \\
\text { Islands" and those made to Government are exempt from this restriction. Section 36(6) of the } \\
\text { Banking Act also allows the FSC to give approval to licensees to book exposures in excess of } \\
25 \text { percent if the licensee agrees to reduce the exposure to within that limit within a period } \\
\text { specified by the FSC. } \\
\text { Paragraph } 5 \text { of Prudential Statement 3-2004 requires the board of directors of licensees to } \\
\text { ensure that on-going reviews of the loan portfolio are conducted to determine among other } \\
\text { things compliance with the above legal provisions. } \\
\text { There is currently no requirement for licensees to report their large exposures to the FSC. }\end{array}$ \\
\hline Assessment & Largely compliant. \\
\hline Comments & $\begin{array}{l}\text { Although the FSC is largely compliant with this principle, the process for allowing exceptions } \\
\text { should be transparent and closely monitored. } \\
\text { A key element in enforcing this law will be ensuring that licensed financial institutions have } \\
\text { appropriate systems to monitor and control exposures of this nature. Examination procedures } \\
\text { and the capture of this information on the prudential returns are also necessary. } \\
\text { PFTAC has agreed to assist the FSC with the preparation of prudential returns including one } \\
\text { for receiving information on concentrations in the loan portfolio. This return should require the } \\
\text { reporting of all loans in excess of } 10 \text { percent of capital and should include sectoral and } \\
\text { geographic exposures. }\end{array}$ \\
\hline Principle 10. & $\begin{array}{l}\text { Connected lending } \\
\text { In order to prevent abuses arising from connected lending, banking supervisors must have in } \\
\text { place requirements that banks lend to related companies and individuals on an arm's-length } \\
\text { basis, that such extensions of credit are effectively monitored, and that other appropriate } \\
\text { steps are taken to control or mitigate the risks. }\end{array}$ \\
\hline Description & $\begin{array}{l}\text { Section 36(6) of the Banking Act } 2003 \text { relating to restrictions on lending extends the } \\
\text { provisions of that section to a director or shareholder to include a spouse, father, mother, son or } \\
\text { daughter and requires that advances to such persons be granted on substantially the same terms } \\
\text { as to members of the public. There is, however, no comprehensive definition of "connected or } \\
\text { related parties" to include the business interests of such persons, neither does the FSC have the } \\
\text { discretion to make judgments about the existence of connections between the bank and other } \\
\text { parties. } \\
\text { There is currently no requirement for approval of a licensee's connected party transactions by } \\
\text { its Board of Directors that are in excess of specified amounts or poses special risks, nor for the } \\
\text { FSC to set limits on such lending or to receive and review information on such lending. }\end{array}$ \\
\hline Assessment & Materially noncompliant. \\
\hline Comments & $\begin{array}{l}\text { The Banking Act } 2003 \text { needs to be amended to include a comprehensive definition of } \\
\text { "connected or related parties" and to give the FSC the discretionary powers in determining the } \\
\text { existence of such relationships and to set limits for transactions to such parties. } \\
\text { The recommended prudential statement pertaining to credit risk management and investments } \\
\text { referred to in Core Principle } 7 \text { should include a requirement for licensees to have documented } \\
\text { policies and procedures for connected lending in keeping with legal limits and be subject to } \\
\text { board approval and on-going monitoring. } \\
\text { The FSC needs to issue a prudential return to measure connected party transactions and to }\end{array}$ \\
\hline
\end{tabular}




\begin{tabular}{|c|c|}
\hline & establish examination procedures. (See comments Core Principle 9). \\
\hline Principle 11. & $\begin{array}{l}\text { Country risk } \\
\text { Banking supervisors must be satisfied that banks have adequate policies and procedures for } \\
\text { identifying, monitoring and controlling country risk and transfer risk in their international } \\
\text { lending and investment activities, and for maintaining appropriate reserves against such } \\
\text { risks. }\end{array}$ \\
\hline Description & $\begin{array}{l}\text { Section } 8(1)(d) \text { and Section } 14(2)(f) \text { of the Banking Act require the FSC to be satisfied that the } \\
\text { risk management systems of applicants are satisfactory prior to issuing a license and on an } \\
\text { ongoing basis. The FSC recognizes its legal responsibilities; however, procedures for } \\
\text { effectively carrying out these responsibilities are still to be prepared and implemented. } \\
\text { Currently the FSC is unaware of the level and nature of country and transfer risk in the } \\
\text { international banks, and no provision in the licensing process explicitly requests this } \\
\text { information. (See Description in Core Principle 7). }\end{array}$ \\
\hline Assessment & Noncompliant. \\
\hline Comments & $\begin{array}{l}\text { Country risk is one of several risk areas, including credit risk, market risk, and other risks, in } \\
\text { which the level and nature of activity and the manner in which the licensed financial } \\
\text { institutions manage these risks must be captured through prudential returns. } \\
\text { The establishment of examination procedures and an appropriate level of training for } \\
\text { examiners in the analysis of country risk, commensurate with licensees' exposure to this type } \\
\text { of risk as reported in their prudential returns, may be required. }\end{array}$ \\
\hline Principle 12. & $\begin{array}{l}\text { Market risks } \\
\text { Banking supervisors must be satisfied that banks have in place systems that accurately } \\
\text { measure, monitor, and adequately control market risks; supervisors should have powers to } \\
\text { impose specific limits and /or a specific capital charge on market risk exposures, if } \\
\text { warranted. }\end{array}$ \\
\hline Description & $\begin{array}{l}\text { Section 14(2)(f) of the Banking Act } 2003 \text { empowers the FSC to ensure that licensed financial } \\
\text { institutions have satisfactory risk management systems. }\end{array}$ \\
\hline Assessment & Noncompliant. \\
\hline Comments & $\begin{array}{l}\text { Market risk is one of several risk areas, including credit risk, country risk, and other risks, in } \\
\text { which the level and nature of activity and the manner in which the licensed financial } \\
\text { institutions manage these risks must be captured through prudential returns. } \\
\text { As with other areas of risk, the establishment of examination procedures and an appropriate } \\
\text { level of training of examiners commensurate with licensees' exposure to market risk may be } \\
\text { required to assess the bank's capabilities in managing this type of risk. } \\
\text { See Description in Core Principle } 7 \text {. }\end{array}$ \\
\hline Principle 13. & $\begin{array}{l}\text { Other risks } \\
\text { Banking supervisors must be satisfied that banks have in place a comprehensive risk } \\
\text { management process (including appropriate board and senior management oversight) to } \\
\text { identify, measure, monitor, and control all other material risks and, where appropriate, to } \\
\text { hold capital against these risks. }\end{array}$ \\
\hline Description & $\begin{array}{l}\text { Sections } 14(2)(\mathrm{d}), 14(2)(\mathrm{f}) \text { and } 14(2 \mathrm{~h}) \text { of the Banking Act } 2003 \text { provides the FSC with the } \\
\text { authority to ensure that licensed financial institutions have satisfactory risk management } \\
\text { systems in liquidity and other risk areas. } \\
\text { As with Core Principles } 11 \text { and } 12 \text {, while the Banking Act } 2003 \text { sets out licensing and on- } \\
\text { going monitoring of risks, no procedures have been developed by the FSC for these areas. }\end{array}$ \\
\hline Assessment & Noncompliant. \\
\hline Comments & $\begin{array}{l}\text { The FSC needs to issue a comprehensive prudential statement on risk management which } \\
\text { would include a requirement for risk management systems to include the following: }\end{array}$ \\
\hline
\end{tabular}




\begin{tabular}{|c|c|}
\hline & $\begin{array}{l}\text { - Liquidity: good management information systems, central liquidity control, } \\
\text { analysis of net funding requirements under alternative scenarios, diversification } \\
\text { of funding sources, stress testing and contingency planning. Liquidity } \\
\text { management should separately address domestic and foreign currencies; } \\
\text { - Interest rate risk: good management information systems and stress testing; and } \\
\text { - Operational risk: internal audit and internal control systems, procedures to } \\
\text { counter fraud, sound business resumption plans, procedures covering major } \\
\text { system modifications, and preparation for significant changes in the business } \\
\text { environment. } \\
\text { Examination procedures also must be developed. } \\
\text { See Description in Core Principle } 7 \text {. }\end{array}$ \\
\hline Principle 14. & $\begin{array}{l}\text { Internal control and audit } \\
\text { Banking supervisors must determine that banks have in place internal controls that are } \\
\text { adequate for the nature and scale of their business. These should include clear arrangements } \\
\text { for delegating authority and responsibility; separation of the functions that involve } \\
\text { committing the bank, paying away its funds, and accounting for its assets and liabilities; } \\
\text { reconciliation of these processes; safeguarding its assets; and appropriate independent } \\
\text { internal or external audit and compliance functions to test adherence to these controls as well } \\
\text { as applicable laws and regulations. }\end{array}$ \\
\hline Description & $\begin{array}{l}\text { Section 14(2(f) of the Banking Act } 2003 \text { enables the FSC to ensure that licensed financial } \\
\text { institutions have satisfactory internal control systems. } \\
\text { Section } 41 \text { of the Banking Act } 2003 \text { requires licensed financial institutions to retain an external } \\
\text { auditor, who must render a report on the audited financial statements of these institutions } \\
\text { annually. The external auditors also must report on the adequacy of internal control systems } \\
\text { (Section 44) at the request of the FSC. } \\
\text { There are no specific provisions in the Banking Act } 2003 \text { nor any prudential statement setting } \\
\text { out the duties and responsibilities of the board of directors with respect to corporate } \\
\text { governance, although there are some responsibilities of the Board articulated in the area of } \\
\text { asset classification, provisioning, and nonaccrual of interest in Prudential Statement 3-2004. } \\
\text { The FSC is required under Section } 8(1) \text { (b) of the Banking Act } 2003 \text { to ensure that directors } \\
\text { have significant experience in banking. However, while Section } 28 \text { gives the FSC the power to } \\
\text { direct a licensee to remove a director, it does not cover incompetence and disregard of duties. } \\
\text { The FSC will collect some information on internal control systems during the licensing } \\
\text { process. However, no prudential standard has been issued by the FSC relating to internal } \\
\text { controls or duties and responsibilities of directors, including the establishment and composition } \\
\text { of an audit committee. } \\
\text { Section 15(1) of the Banking Act empowers the FSC to examine the records of a licensee, } \\
\text { including reports of the internal auditor. An on-site examination program, which includes the } \\
\text { review of the internal audit function, has not yet been established. }\end{array}$ \\
\hline Assessment & Materially noncompliant. \\
\hline Comments & $\begin{array}{l}\text { The FSC recognizes the deficiencies in the area of internal controls and a prudential statement } \\
\text { on corporate governance is to be drafted. The FSC should ensure that this prudential statement } \\
\text { addresses the issues noted above including internal control requirements such as delegating } \\
\text { authority and responsibility, separation of functions and accounting for its assets and liabilities, } \\
\text { reconciliation of these processes, and appropriate independent internal or external audit and }\end{array}$ \\
\hline
\end{tabular}




\begin{tabular}{|c|c|}
\hline & $\begin{array}{l}\text { compliance functions. } \\
\text { On-site review and inspection procedures for assessing the effectiveness of board oversight } \\
\text { and the internal audit function also need to be developed and documented by the FSC and its } \\
\text { examiners trained in the required examination procedures. }\end{array}$ \\
\hline Principle 15. & $\begin{array}{l}\text { Money laundering } \\
\text { Banking supervisors must determine that banks have adequate policies, practices and } \\
\text { procedures in place, including strict "know-your-customer" rules, which promote high ethical } \\
\text { and professional standards in the financial sector and prevent the bank being used, } \\
\text { intentionally or unintentionally, by criminal elements. }\end{array}$ \\
\hline Description & $\begin{array}{l}\text { The provisions of Part } 2 \text { and } 3 \text { of the Financial Transactions Reporting Act } 2003 \text { include } \\
\text { requirements for financial institutions to identify and verify customer identity, maintain } \\
\text { transaction records, monitor transactions, and report large and suspicious transactions. Section } \\
12 \text { sets out the obligations of the FSC and auditors regarding reporting suspicious transactions } \\
\text { to the FIU while Section } 16 \text { provides protection for persons reporting in good faith. Section } 28 \\
\text { also allows the FIU to disclose information to foreign agencies and sets out the conditions } \\
\text { under which information could be shared. } \\
\text { Section } 17 \text { of the FSCA makes it a condition of a license issued to a financial institution that it } \\
\text { must have a person appointed and holding office as a compliance officer with responsibility for } \\
\text { establishing and maintaining office and accounting procedures including customer } \\
\text { identification and recordkeeping procedures as may be prescribed by regulation. } \\
\text { The Financial Supervisory Commission (Qualification of Compliance Officers) Regulations } \\
\text { 2004, the Financial Transactions Reporting (Customer Identification) Regulations } 2004 \text {, and } \\
\text { Financial Transactions Reporting (Forms) Regulations } 2004 \text { were issued by the Cook Islands } \\
\text { Government in February } 2004 \text { and include the forms to be used by financial institutions to } \\
\text { report prescribed information to the FIU. } \\
\text { The FSC is in the process of developing a close working relationship with the FIU, which has } \\
\text { enforcement powers under Section } 31 \text { of the Financial Transactions Reporting Act } 2003 \text { for } \\
\text { compliance with anti-money laundering requirements. The FSC's examiners have been } \\
\text { attending FIU training sessions and similar training is also planned for the future. } \\
\text { While the legal framework is in place, requiring financial institutions licensed by the FSC to } \\
\text { have in place know-your-customer procedures and to monitor and report suspicious activity, no } \\
\text { on-site examinations of licensed financial institutions have as yet been carried out by the FSC } \\
\text { to determine compliance with the provisions of the Financial Transactions Reporting Act } 2003 \\
\text { and the enabling regulations noted above. }\end{array}$ \\
\hline Assessment & Materially noncompliant. \\
\hline Comments & $\begin{array}{l}\text { On-site examination procedures need to be developed by the FSC in collaboration with the FIU } \\
\text { to enable it to determine whether financial institutions have in place policies, practices, and } \\
\text { procedures for preventing them from being used by criminal elements including the existence } \\
\text { of procedural manuals and adequate staff training in customer identification and transaction } \\
\text { record-keeping as well as their compliance with the relevant laws and regulations and reporting } \\
\text { obligations. } \\
\text { Training of the FSC's examiners needs to be expanded to include methodologies for reviewing } \\
\text { the anti-money laundering procedural manuals and transaction and reporting records of the } \\
\text { licensed financial institutions and the preparation of reports to the FIU. } \\
\text { The FSC needs to agree with the FIU on procedures for reporting its findings following on-site } \\
\text { inspections. }\end{array}$ \\
\hline
\end{tabular}




\begin{tabular}{|c|c|}
\hline Principle 16. & $\begin{array}{l}\text { On-site and off-site supervision } \\
\text { An effective banking supervisory system should consist of some form of both on-site and off- } \\
\text { site supervision. }\end{array}$ \\
\hline Description & $\begin{array}{l}\text { Sections } 14 \text { and } 15 \text { of the Banking Act } 2003 \text { empower the FSC to: } \\
\text { - } \quad \text { review banking business and implement internationally accepted standards for the } \\
\text { prudential supervision of banking business; } \\
\text { inspect the premises and business, within or outside the Cook Islands, including the } \\
\text { - } \quad \text { insstems and controls, of a licensee, and; } \\
\text { The FSC's resources at present are being devoted almost entirely to preparation for the review } \\
\text { of licensing applications that will be submitted by March 1, 2004. Virtually all FSC resources } \\
\text { will be employed in the analysis of these applications until approximately June1, } 2004 \text {. } \\
\text { At present, the FSC has no infrastructure to conduct an on-site and off-site supervision } \\
\text { program. Staff lacks experience and training in both processes, and cannot be expected to } \\
\text { perform work in either area without on-the-job guidance. There are no prudential returns from } \\
\text { which to base an off-site analytical process, and systems to detect trends or issues have not } \\
\text { been developed. Broad-based examination tools such as an examination report and manual } \\
\text { have not been developed, nor have tools to assess credit risk, liquidity risk and other banking } \\
\text { risks. } \\
\text { At least for the first two years or more, the FSC proposes that on-site examinations will consist } \\
\text { principally of a compliance rather than risk-based approach because of the need to train and } \\
\text { develop the supervision staff. Risk-based supervision requires a staff with a higher level of } \\
\text { training and sophistication than the FSC staff possesses at present. } \\
\text { The FSC conducted its first on-site examination from February } 4-12,2004 \text {. The scope of the } \\
\text { examination was to seek an understanding of the management systems and internal contol } \\
\text { environment of the Bank of the Cook Islands with a view to determine whether the bank would } \\
\text { satisfy the requirements for the issuance of a license to conduct a banking business. The } \\
\text { examination team concentrated on the bank's credit risk management systems. The examination } \\
\text { was led by a banking supervision advisor from PFTAC, who also provided on-the-job training } \\
\text { to the FSC's two bank supervisors. }\end{array}$ \\
\hline Assessment & Noncompliant. \\
\hline Comments & $\begin{array}{l}\text { It will be a massive undertaking for the FSC to develop a robust on-site and off-site supervision } \\
\text { function. The Commissioner will have to prioritize areas of need. Initially, the FSC may want } \\
\text { to concentrate on the training of its staff. A formalized training program would be warranted } \\
\text { which could incorporate a secondment to other supervisors so that FSC staff may gain a } \\
\text { measure of sophistication prior to implementing an on-site program in the Cook Islands. The } \\
\text { training program also could serve as an accreditation program for examiners, reflecting a ladder } \\
\text { of achievement and providing a career path. Such a program also could promote retention of } \\
\text { supervisory staff. Development of prudential returns is also a matter of top priority, together } \\
\text { with establishment of an off-site function to assess the information contained in these reports. } \\
\text { Examination tools also will have to be developed early to enable the supervision staff to be } \\
\text { more effective when they are on site. }\end{array}$ \\
\hline Principle 17. & $\begin{array}{l}\text { Bank management contact } \\
\text { Banking supervisors must have regular contact with bank management and a thorough } \\
\text { understanding of the institution's operations. }\end{array}$ \\
\hline Description & $\begin{array}{l}\text { The FSC does not have a program of routine contact with the management of supervised } \\
\text { institutions, but is well aware of the need to do so. The FSC has had irregular contact with } \\
\text { licensed financial institutions to date, describing current activity in that regard as "an open door } \\
\text { policy." More appropriately, a program to meet with each institution, particularly the }\end{array}$ \\
\hline
\end{tabular}




\begin{tabular}{|c|c|}
\hline & $\begin{array}{l}\text { international banks, would have enabled the FSC to be more knowledgeable of their business } \\
\text { activities and risk profile. This is the only medium the FSC has had at its disposal in the } \\
\text { absence of prudential returns and an on-site and off-site program. As a consequence, the FSC } \\
\text { has virtually no information or insights in the activities of the international banks pending } \\
\text { receipt of their applications for a license at the beginning of March. The best that can be said at } \\
\text { present is that the FSC will be considering the quality of management very closely during the } \\
\text { licensing process. However, the FSC will have met with very few of them. }\end{array}$ \\
\hline Assessment & Noncompliant. \\
\hline Comments & $\begin{array}{l}\text { The Commissioner recognizes the value of regular contact with bank management, and plans to } \\
\text { institute a more formal program subsequent to completion of the licensing process at mid-year. } \\
\text { At a minimum, the Commissioner intends to meet with management of each institution at least } \\
\text { annually to discuss strategic issues and bank performance. Meetings with these institutions on } \\
\text { operational matters will occur more frequently based on the results of the on-site and off-site } \\
\text { supervision functions. }\end{array}$ \\
\hline Principle 18. & $\begin{array}{l}\text { Off-site supervision } \\
\text { Banking supervisors must have a means of collecting, reviewing and analyzing prudential } \\
\text { reports and statistical returns from banks on a solo and consolidated basis. }\end{array}$ \\
\hline Description & $\begin{array}{l}\text { Section 18(2)(b) of the Banking Act } 2003 \text { provides the FSC with the power to require a } \\
\text { financial institution to supply information in support of its performance in supervising the } \\
\text { institution. Section } 14(\mathrm{~d}) \text { of the Banking Act } 2003 \text { enables the FSC to collect and analyze } \\
\text { information related to prudential matters relating to licensed financial institutions. The FSC has } \\
\text { used these provisions to institute Prudential Statement } 2-2004 \text {, which requires the filing of a } \\
\text { report on capital adequacy on a quarterly basis. At present, no wider scope periodic prudential } \\
\text { return on either a stand-alone or a consolidated basis is required of licensed financial } \\
\text { institutions. The FSC recognizes the necessity of instituting such a reporting program and } \\
\text { intends to give it high priority subsequent to completion of the assessment of the licensing } \\
\text { applications. An off-site supervision function will be created to analyze data from the returns. } \\
\text { The FSC can enforce compliance with the cited provisions of the Banking Act } 2003 \text { by issuing } \\
\text { directives against the institution that would restrict its business activities or compel it in some } \\
\text { other way to comply with information requirements. }\end{array}$ \\
\hline Assessment & Materially noncompliant. \\
\hline Comments & $\begin{array}{l}\text { While the FSC's ability to issue directives against an institution does enable it to apply } \\
\text { sanctions in the event of noncompliance in providing information to the FSC, the law could be } \\
\text { stronger in this regard. A more effective approach is to make noncompliance a punishable } \\
\text { offense, with a prescribed fine, as is the case for certain other areas of noncompliance with the } \\
\text { Banking Act } 2003 \text {. } \\
\text { As part of its efforts in collecting data through prudential returns, the FSC may want to } \\
\text { consider obtaining adequate technology capabilities so that the returns can be automated. This } \\
\text { would facilitate analysis of the data, and would enable the FSC to create a peer group for the } \\
\text { international banks. The FSC would be able to compare performance more easily, identify } \\
\text { trends and quantify differences in the banking business of this group of institutions. Such } \\
\text { information would be a valuable tool in policy development and in developing supervisory } \\
\text { strategies. } \\
\text { PFTAC has offered to assist the FSC in developing a set of prudential returns that could be } \\
\text { communicated to licensed financial institutions in time for a first time filing date as } \\
\text { of June } 30,2004 \text {. The FSC is very receptive in obtaining technical assistance from PFTAC for } \\
\text { this purpose. }\end{array}$ \\
\hline Principle 19. & $\begin{array}{l}\text { Validation of supervisory information } \\
\text { Banking supervisors must have a means of independent validation of supervisory information } \\
\text { either through on-site examinations or use of external auditors. }\end{array}$ \\
\hline
\end{tabular}




\begin{tabular}{|c|c|}
\hline Description & $\begin{array}{l}\text { The FSC does not have a functioning on-site supervision process at present, and therefore has } \\
\text { limited capacity to validate supervisory information. Supervision staff must be trained and } \\
\text { supervisory and examination tools, as described in Principle 16, must be developed. The only } \\
\text { on-site examination activity occurring at present is in support of evaluation of applications for } \\
\text { the licensing of financial institutions. Only one such examination has taken place to date, an } \\
\text { examination of Bank of the Cook Islands, which was conducted with technical assistance from } \\
\text { an advisor of PFTAC. } \\
\text { An option that the FSC may explore is the utilization of external auditors either as a substitute } \\
\text { for or complement to on-site examination work accomplished by FSC staff. Section } 44 \text { of the } \\
\text { Banking Act } 2003 \text { gives the FSC the authority to appoint a licensee's external auditor to } \\
\text { conduct an audit, and report through the licensed financial institution on any matter the FSC } \\
\text { determines, including asset quality, adequacy of loan loss provisions, and accounting and } \\
\text { control systems. Under this provision, the Commissioner could require external auditors to } \\
\text { check prudential returns, when they are developed. } \\
\text { The Banking Act } 2003 \text { has no explicit provision requiring external auditors to meet with the } \\
\text { FSC on the results of audits, but Section } 43 \text { requires the auditor to report information to the } \\
\text { FSC obtained during the course of the audit that would indicate that the institution is insolvent, } \\
\text { a criminal offense or fraud has been committed, serious irregularities have occurred in the } \\
\text { management of risk, losses incurred seriously reduce the institution's capital position, or the } \\
\text { institution has failed to comply with a directive or guideline issued by the FSC. }\end{array}$ \\
\hline Assessment & Noncompliant. \\
\hline & $\begin{array}{l}\text { The largest issue in the employment of external auditors may be their competence and } \\
\text { reputation as a group. Over the years, approximately } 200 \text { auditors and audit firms from all over } \\
\text { the world have been registered to act as external auditors in the Cook Islands. Registration of } \\
\text { these entities was accomplished through the International Companies Act 1981-82, with } \\
\text { applications typically submitted by trust companies operating on the Island on their behalf. As } \\
\text { a practical matter, many of these applications appear to have become "rubber stamp" approvals, } \\
\text { as no background checks were done on the entities or individuals, and no evidence was } \\
\text { submitted that they were even certified as auditors or accountants. Therefore, the qualifications } \\
\text { of the auditors on the roster may be thrown into question. } \\
\text { With the creation of the FSC, responsibility for registering approved auditors has been } \\
\text { transferred to the FSC. The FSC is in a good position to undertake a vigorous review of the } \\
\text { registration process, and enhance it where due diligence weaknesses are identified. It also may } \\
\text { be necessary for the FSC to require the current listing of registered auditors to complete a re- } \\
\text { registration process to update the current listing and enable the FSC to perform appropriate due } \\
\text { diligence. } \\
\text { Section } 43 \text { should be amended to require external auditors to report information on a breach of } \\
\text { the FSCA or the Banking Act } 2003 \text { by the institution. }\end{array}$ \\
\hline & $\begin{array}{l}\text { Consolidated supervision } \\
\text { An essential element of banking supervision is the ability of the supervisors to supervise the } \\
\text { banking group on a consolidated basis. }\end{array}$ \\
\hline Description & $\begin{array}{l}\text { The FSC has virtually no knowledge of the overall structure of the international financial } \\
\text { institutions whose applications for a license to conduct a banking business it will be evaluating. } \\
\text { Moreover, the FSC has not yet determined the manner in which it will attempt to supervise } \\
\text { material parts of these groups or how to evaluate the risks they may pose to the consolidated } \\
\text { group. } \\
\text { Section } 5 \text { of the Bank of the Cook Islands Act } 2003 \text { granted a transitional banking license to the } \\
\text { Bank of the Cook Islands Holding Corporation, which expires on June } 4,2004 \text {. In June } 2004 \text {, }\end{array}$ \\
\hline
\end{tabular}




\begin{tabular}{|c|c|}
\hline & $\begin{array}{l}\text { subject to approval by the FSC of a license to conduct a banking business by the Bank of Cook } \\
\text { Islands, Ltd., the holding company will no longer be subject to the supervision of the FSC. The } \\
\text { FSC's supervision authority will extend only to this bank subsidiary. The bank is a } \\
\text { subsidiary, of the Holding Corporation which is also affiliated to other nonbank entities, } \\
\text { namely the Development Finance Limited and CIDB Former Loans Ltd. } \\
\text { There are no provisions in the law that requires the FSC to be satisfied that the ownership and } \\
\text { organizational structures of licensed financial institutions do not obstruct the conduct of } \\
\text { effective consolidated supervision. }\end{array}$ \\
\hline Assessment & Noncompliant. \\
\hline Comments & $\begin{array}{l}\text { In light of the impending volume of licensing applications from the international banking } \\
\text { institutions, the FSC may want to consider very seriously and communicate to applicants its } \\
\text { vision for the type of financial institution that is desired for the Cook Islands both for the } \\
\text { present and in the future. In connection with this policy decision, the FSC should consider the } \\
\text { issuance of a Prudential Statement defining comprehensive supervision on a consolidated basis, } \\
\text { and the implications for licensees from the standpoint of their organizational structure, } \\
\text { operations, and the quality and type of information that must be reported to the FSC. } \\
\text { The supervision of Bank of the Cook Islands presents a special challenge for the FSC, as it } \\
\text { must supervise it on a stand-alone basis after June } 4,2004 \text { when the holding company's } \\
\text { transitional banking license expires. Consequently, the FSC will be unable to undertake the } \\
\text { prudential supervision of the bank on a comprehensive consolidated basis. At a minimum, } \\
\text { arrangements must be made to enable the FSC to review the consolidated operations of the } \\
\text { holding company to ensure the safety and soundness of the bank. The FSC must be able to take } \\
\text { a view on critical areas such as connected lending and, large exposures on a consolidated basis. } \\
\text { It must have information on the financial condition of the holding company on a stand- } \\
\text { alone and consolidated basis, and on the financial condition of each nonbank affiliate. It } \\
\text { must also have information on the nature, volume and type of transactions and flow of funds } \\
\text { between the bank and its affiliates and the holding company. }\end{array}$ \\
\hline & $\begin{array}{l}\text { Accounting standard } \\
\text { Banking supervisors must be satisfied that each bank maintains adequate records drawn up in } \\
\text { accordance with consistent accounting policies and practices that enable the supervisor to } \\
\text { obtain a true and fair view of the financial condition of the bank and the profitability of its } \\
\text { business, and that the bank publishes on a regular basis financial statements that fairly reflect } \\
\text { its condition. }\end{array}$ \\
\hline Description & $\begin{array}{l}\text { Section } 26 \text { of the Banking Act } 2003 \text { requires a licensee to keep and maintain accounting } \\
\text { records that are necessary to disclose with reasonable accuracy the financial position of the } \\
\text { licensee, while Section } 42 \text { requires licensees to have annual auditor's reports prepared and } \\
\text { submitted to the FSC within four months of the close of their financial year. It also sets out } \\
\text { information that should be included in the auditor's report, such as whether the balance sheet of } \\
\text { the licensee and its subsidiaries gives a true and fair view of the state of affairs of the licensee. } \\
\text { Section } 43 \text { of the Banking Act } 2003 \text { requires an auditor to disclose to the FSC information } \\
\text { relating to the affairs of the licensee obtained during the audit including, if in its opinion: } \\
\text { - the licensee is likely to become insolvent or be unable to meet its obligations or is in } \\
\text { - serious financial difficulties; } \\
\text { - a criminal offence involving fraud or dishonesty may have been committed; } \\
\text { serious irregularities have occurred including irregularities that may place at risk the } \\
\text { interest of depositors; } \\
\text { - losses incurred that substantially reduce the capital of the licensee; and } \\
\text { the licensee has failed to comply with a directive or guideline issued by the FSC. } \\
\text { It also facilitates discussion of the audit between the auditor and the FSC and requires the }\end{array}$ \\
\hline
\end{tabular}




\begin{tabular}{|c|c|}
\hline & $\begin{array}{l}\text { auditor to provide such additional information as the FSC may require. } \\
\text { In addition, under Section } 44 \text { of the Banking Act, the FSC may require a licensee to have its } \\
\text { auditor provide the FSC with a report on asset quality, adequacy of loss provisions and the } \\
\text { accounting and control systems and such other matters as the FSC may determine. } \\
\text { Section } 41(2) \text { of the Banking Act } 2003 \text { requires a licensee's auditor to be experienced in } \\
\text { auditing business and to be approved by the FSC. Auditors for banks incorporated under the } \\
\text { International Business Companies Act, that is, the international banks, need to be registered by } \\
\text { the FSC, and as part of the registration process are required to be suitably qualified and to } \\
\text { declare the country law under which they are registered as a company auditor. The processes } \\
\text { currently used by the FSC for registering auditors do not include ensuring that the information } \\
\text { submitted by trust companies complies with the requirements of the International Companies } \\
\text { Act and no due diligence checks on applicants to confirm their qualifications or affiliation to an } \\
\text { accounting body are carried out prior to registration. } \\
\text { The FSC can appoint an auditor under Section } 41(3) \text { of the Banking Act } 2003 \text { if the licensee } \\
\text { fails to appoint an approved auditor and also under Section } 17(2) \text { as part of its enforcement } \\
\text { powers. However, the FSC has no power to revoke the appointment of a licensee's auditor. } \\
\text { There is also no requirement in the Banking Act } 2003 \text { for the financial statements to be } \\
\text { prepared in accordance with acceptable accounting standards or for licensees to publish their } \\
\text { audited financial statements. } \\
\text { There are no specific requirements in the Banking Act } 2003 \text { for licensees to submit periodic } \\
\text { prudential reports to the FSC. However, it proposes to issue a prudential guideline under } \\
\text { Section } 14(3) \text { of the Banking Act } 2003 \text { to require the submission of prudential returns for the } \\
\text { various operations of licensees, as it has done for capital adequacy and asset classification. } \\
\text { The operational procedures of the FSC are still in the formative stage and procedures for } \\
\text { ensuring compliance with the accounting and audit requirements of the Banking Act } 2003 \text { are } \\
\text { still to be implemented. }\end{array}$ \\
\hline & Materially noncompliant. \\
\hline Comments & $\begin{array}{l}\text { The FSC needs to document the criteria for approving auditors under Section } 41 \text { of the Banking } \\
\text { Act } 2003 \text {, which should include affiliation with an approved professional body. It should also } \\
\text { require that the financial statements of all licensees are prepared in accordance with } \\
\text { internationally accepted accounting standards. A prudential statement pertaining to these issues } \\
\text { should therefore be issued by the FSC. } \\
\text { Licensees should also be required to publish their audited financial statements and display } \\
\text { copies for public perusal in their offices and in any other media as may be required by the FSC. } \\
\text { The FSC also needs to establish supervisory procedures for ensuring that licensees comply with } \\
\text { audit requirements and train its examiners to review and assess audit reports. }\end{array}$ \\
\hline Principle 22. & $\begin{array}{l}\text { Remedial measures } \\
\text { Banking supervisors must have at their disposal adequate supervisory measures to bring } \\
\text { about timely corrective action when banks fail to meet prudential requirements (such as } \\
\text { minimum capital adequacy ratios), when there are regulatory violations, or where depositors } \\
\text { are threatened in any other way. In extreme circumstances, this should include the ability to } \\
\text { revoke the banking license or recommend its revocation. }\end{array}$ \\
\hline Description & $\begin{array}{l}\text { Section 17(1) of the Banking Act } 2003 \text { allows the FSC to take enforcement action against } \\
\text { licensed financial institutions under several circumstances. The FSC would consider whether an } \\
\text { institution: }\end{array}$ \\
\hline
\end{tabular}




\begin{tabular}{|c|c|}
\hline & 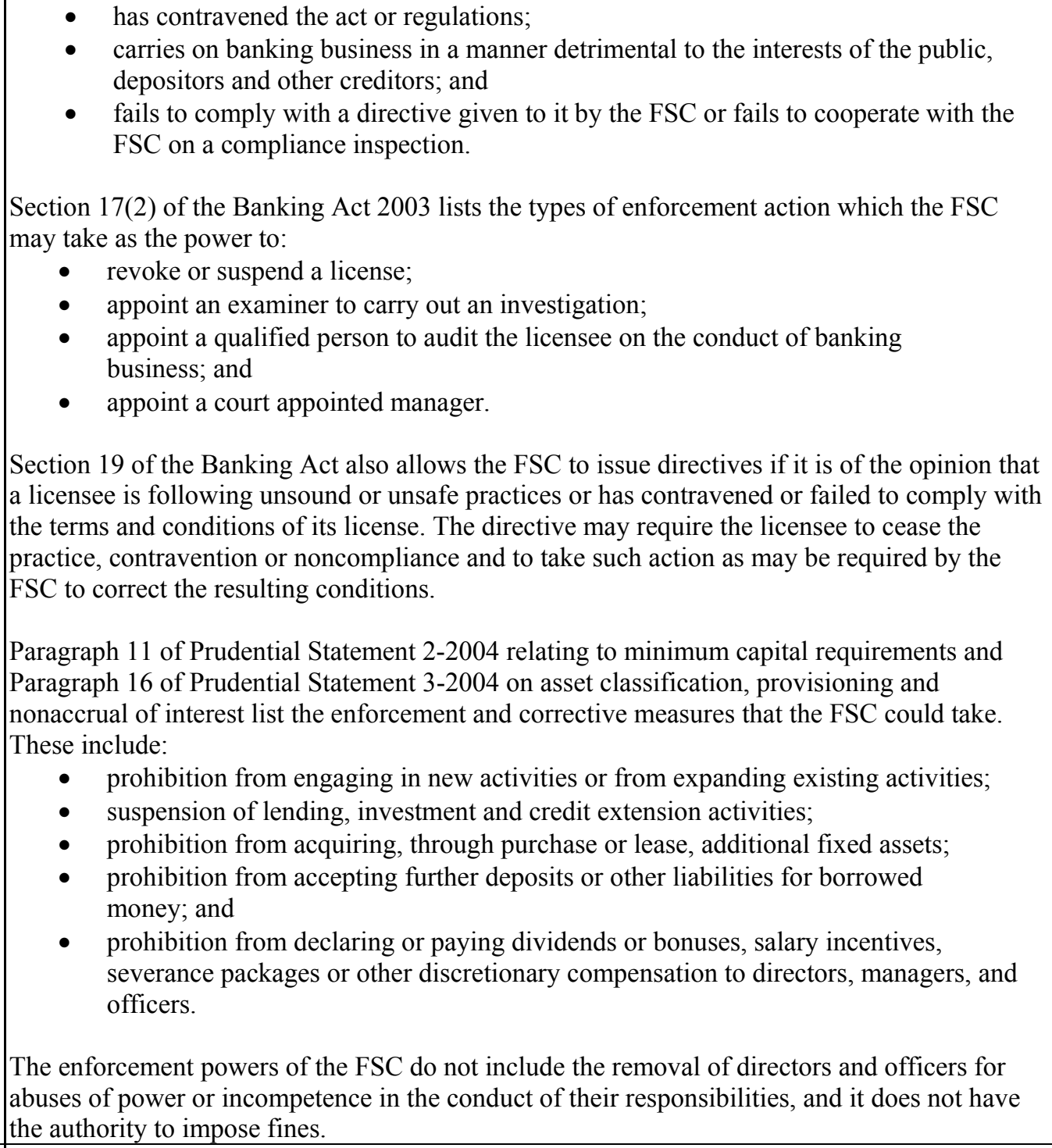 \\
\hline Assessment & Largely compliant \\
\hline Comments & $\begin{array}{l}\text { The FSC has a range of enforcement measures at its disposal. However, since the FSC was only } \\
\text { recently established and has issued no license to date, no opportunity has yet arisen for it to } \\
\text { apply any of these measures. } \\
\text { The provisions of Section } 19(2)(\text { b) of the Banking Act } 2003 \text { should be strengthened to allow } \\
\text { the FSC to remove directors who abuse power or whose actions have resulted in the interests of } \\
\text { depositors and other creditors being threatened. The FSC should also have the power to impose } \\
\text { fines for minor offences such as the late or inaccurate submission of prudential returns. } \\
\text { The FSC should also issue a prudential statement setting out a ladder of compliance, which } \\
\text { would allow licensed financial institutions to be aware of the actions that can be applied against } \\
\text { them. }\end{array}$ \\
\hline Principle 23. & $\begin{array}{l}\text { Globally consolidated supervision } \\
\text { Banking supervisors must practice global consolidated supervision over their internationally } \\
\text { active banking organizations, adequately monitoring and applying appropriate prudential } \\
\text { norms to all aspects of the business conducted by these banking organizations worldwide, }\end{array}$ \\
\hline
\end{tabular}




\begin{tabular}{|c|c|}
\hline Description & $\begin{array}{l}\text { Under Section } 29 \text { of the Banking Act } 2003 \text {, a bank incorporated and licensed in the Cook } \\
\text { Islands must obtain the written approval of the FSC prior to conducting banking business } \\
\text { through an overseas office, branch or subsidiary. This section also requires that the overseas } \\
\text { operations will be subject to adequate banking supervision and that the FSC is allowed access } \\
\text { to any required information or document. } \\
\text { The FSC has no specific powers to require a licensee to close an overseas operation, but this } \\
\text { may be invoked as part of the FSC's enforcement powers. } \\
\text { There is no consolidated supervision undertaken by the FSC at present, as it is not currently } \\
\text { aware of the existence of overseas activities for any locally incorporated banks. }\end{array}$ \\
\hline Assessment & Noncompliant. \\
\hline Comments & $\begin{array}{l}\text { The requirement for all existing licensees to re-apply for a new license by March } 1,2004 \text { under } \\
\text { the Banking Act 2003, will inform the FSC of those entities with overseas operations. The FSC } \\
\text { will then have to discuss with such entities the nature and extent of their operations. } \\
\text { The FSC needs to develop returns for obtaining prudential information on the global operations } \\
\text { of licensees and establish systems and procedures for supervising these licensees on a } \\
\text { consolidated basis. Communications with host country supervisors also will have to be opened } \\
\text { to facilitate supervision of the licensed financial institution globally. } \\
\text { Examiners will also have to be trained in consolidated supervision. }\end{array}$ \\
\hline Principle 24. & $\begin{array}{l}\text { Host country supervision } \\
\text { A key component of consolidated supervision is establishing contact and information } \\
\text { exchange with the various other supervisors involved, primarily host country supervisory } \\
\text { authorities. }\end{array}$ \\
\hline Description & $\begin{array}{l}\text { The FSC can share information with supervisory authorities under both Section } 46(3) \text { of the } \\
\text { Banking Act } 2003 \text { and Section } 23 \text { of the FSCA subject to adequate legal restrictions on further } \\
\text { disclosure and the information disclosed being required for regulatory or law enforcement } \\
\text { purposes. Penalties for unauthorized disclosure are also included in these laws. } \\
\text { There is no consolidated supervision undertaken by the FSC at present, as it is not currently } \\
\text { aware of the existence of overseas activities for any locally incorporated banks and as such, } \\
\text { there has been no contact or information exchange with any host country supervisory authority. } \\
\text { Moreover, the development of a host country supervision program has not been actively } \\
\text { considered. }\end{array}$ \\
\hline Assessment & Noncompliant. \\
\hline Comments & $\begin{array}{l}\text { It may be necessary for the FSC to develop a foreign bank supervision program that encourages } \\
\text { host country supervisors to examine overseas operations of financial institutions licensed in the } \\
\text { Cook Islands, and to develop a communication process to share supervisory information. The } \\
\text { nature and scope of the program will depend on the organizational structure of applicants and } \\
\text { the extent of their financial operations outside of the Cook Islands. }\end{array}$ \\
\hline Principle 25. & $\begin{array}{l}\text { Supervision over foreign banks' establishments } \\
\text { Banking supervisors must require the local operations of foreign banks to be conducted to the } \\
\text { same high standards as are required of domestic institutions and must have powers to share } \\
\text { information needed by the home country supervisors of those banks for the purpose of } \\
\text { carrying out consolidated supervision. }\end{array}$ \\
\hline Description & $\begin{array}{l}\text { The new licensing requirements under Section } 8 \text { of the Banking Act } 2003 \text { and Prudential } \\
\text { Statement 1-2004 on "Bank Licensing-Requirements, Policies and Procedures" apply to both } \\
\text { domestic and foreign banks (see Core Principle 3). In addition, Section } 9 \text { of the Banking Act } \\
2003 \text { sets out additional criteria for the licensing of foreign banks including: } \\
\text { - the reputation of the foreign bank is satisfactory; }\end{array}$ \\
\hline
\end{tabular}




\begin{tabular}{|c|c|}
\hline & 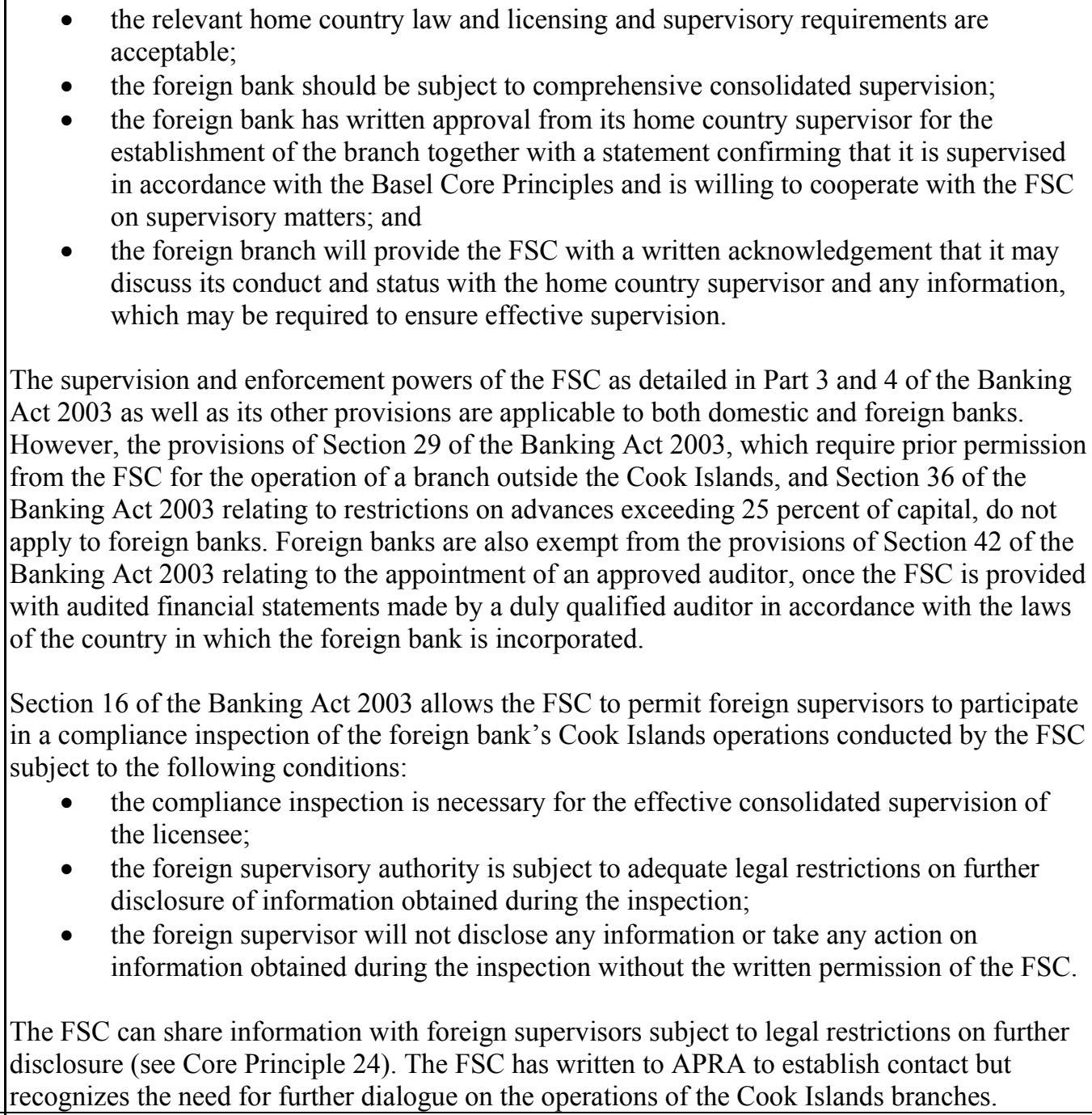 \\
\hline Assessment & Largely compliant. \\
\hline Comments & $\begin{array}{l}\text { There are two Australian bank branches currently operating in the Cook Islands. The Cook } \\
\text { Islands operations of the two Australian banks are microscopic in relation to their overall } \\
\text { operations and are not material to the APRA's overview of the banks' consolidated operations. } \\
\text { However, from an operational risk perspective, the FSC would wish to ensure that foreign } \\
\text { banks are fully compliant with the provisions of the Financial Transactions Reporting Act } 2003 . \\
\\
\text { APRA has indicated a willingness to assist the FSC with reviewing the operations of these two } \\
\text { branches from a training perspective. The FSC therefore needs to develop working } \\
\text { relationships with APRA as it seeks to develop its on-site and off-site supervisory procedures. }\end{array}$ \\
\hline
\end{tabular}




\section{Summary Compliance of the Basel Core Principles}

\section{Table 2. Summary Compliance of the Basel Core Principles}

\begin{tabular}{|c|c|c|c|c|c|}
\hline Core Principle & $\mathrm{C}^{1 /}$ & $\mathrm{LC}^{2 /}$ & $\mathrm{MNC}^{-3}$ & $\mathrm{NC}^{4 /}$ & $\mathrm{NA}^{\frac{5 /}{1}}$ \\
\hline \multicolumn{6}{|l|}{ 1. Objectives, Autonomy, Powers, and Resources } \\
\hline 1.1 Objectives & & $\mathbf{X}$ & & & \\
\hline 1.2 Independence & & & $\mathbf{X}$ & & \\
\hline 1.3 Legal framework & $\mathbf{X}$ & & & & \\
\hline 1.4 Enforcement powers & $\mathbf{X}$ & & & & \\
\hline 1.5 Legal protection & $\mathbf{X}$ & & & & \\
\hline 1.6 Information sharing & & $\mathbf{X}$ & & & \\
\hline 2. Permissible Activities & & $\mathbf{X}$ & & & \\
\hline 3. Licensing Criteria & & $\mathbf{X}$ & & & \\
\hline 4. Ownership & & $\mathbf{X}$ & & & \\
\hline 5. Investment Criteria & & $\mathbf{X}$ & & & \\
\hline 6. Capital Adequacy & $\mathbf{X}$ & & & & \\
\hline 7. Credit Policies & & & $\mathbf{X}$ & & \\
\hline 8. Loan Evaluation and Loan-Loss Provisioning & & $\mathbf{X}$ & & & \\
\hline 9. Large Exposure Limits & & $\mathbf{X}$ & & & \\
\hline 10. Connected Lending & & & $\mathbf{X}$ & & \\
\hline 11. Country Risk & & & & $\mathbf{X}$ & \\
\hline 12. Market Risks & & & & $\mathbf{X}$ & \\
\hline 13. Other Risks & & & & $\mathbf{X}$ & \\
\hline 14. Internal Control and Audit & & & $\mathbf{X}$ & & \\
\hline 15. Money Laundering & & & $\mathbf{X}$ & & \\
\hline 16. On-Site and Off-Site Supervision & & & & $\mathbf{X}$ & \\
\hline 17. Bank Management Contact & & & & $\mathbf{X}$ & \\
\hline 18. Off-Site Supervision & & & $\mathbf{X}$ & & \\
\hline 19. Validation of Supervisory Information & & & & $\mathbf{X}$ & \\
\hline 20. Consolidated Supervision & & & & $\mathbf{X}$ & \\
\hline 21. Accounting Standards & & & $\mathbf{X}$ & & \\
\hline 22. Remedial Measures & & $\mathbf{X}$ & & & \\
\hline 23. Globally Consolidated Supervision & & & & $\mathbf{X}$ & \\
\hline 24. Host Country Supervision & & & & $\mathbf{X}$ & \\
\hline $\begin{array}{l}\text { 25. Supervision Over Foreign Banks' } \\
\text { Establishments }\end{array}$ & $\mathbf{X}$ & & & & \\
\hline 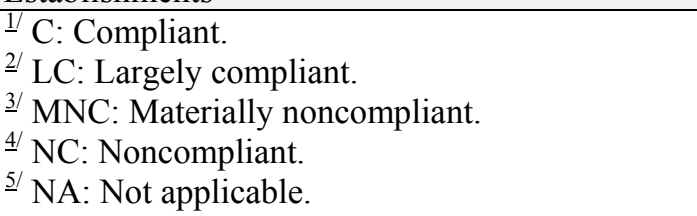 & & & & & \\
\hline
\end{tabular}




\section{Recommendations}

\section{Table 3. Recommended Action Plan to Improve Compliance of the Basel Core Principle}

\begin{tabular}{|c|c|}
\hline Reference Principle & Recommended Action \\
\hline 1(1) Clear responsibilities and objectives & $\begin{array}{l}\text { Provisions of law relating to problem bank resolution are not } \\
\text { addressed fully in the law. The FSC's enforcement action } \\
\text { authority enables it to retain a court appointed manager to } \\
\text { conduct or wind down the business of an institution. However, } \\
\text { there are no specific provisions of law pertaining to receivership } \\
\text { or liquidation proceedings. } \\
\text { The Banking Act } 2003 \text { should be amended to add provisions } \\
\text { specifically addressing these conditions, together with powers } \\
\text { granted to the FSC in the event of a liquidity crisis. }\end{array}$ \\
\hline 1(2) Independence & $\begin{array}{l}\text { The current hiring practices of the FSC raise questions of } \\
\text { succession and sustainability at the FSC. A program must be } \\
\text { developed to educate and compensate staff at a level that would } \\
\text { encourage their retention, identify staff members who can } \\
\text { assume leadership roles, and develop career paths for them. The } \\
\text { FSC should explore creative ways under which senior staff can } \\
\text { be attracted from the Cook Islands Diaspora, especially in New } \\
\text { Zealand, as well as locally. Filling vacancies on a contract basis } \\
\text { with expatriates places management continuity and capacity at } \\
\text { risk. }\end{array}$ \\
\hline 1(2). Independence & $\begin{array}{l}\text { While it is recognized that the FSC is in its infancy, and that the } \\
\text { Board and the Commissioner are establishing the framework for } \\
\text { a working relationship, the Commissioner should not be in a } \\
\text { position where routine operational issues are presented to the } \\
\text { Board prior to or concurrently with action taken. The Board } \\
\text { should be involved intimately with policy matters, but not in the } \\
\text { day-to-day operations of the FSC. }\end{array}$ \\
\hline 1(6). Arrangements for information sharing & $\begin{array}{l}\text { The Confidentiality and Disclosure provisions of the Banking } \\
\text { Act } 2003 \text { and the FCSA are inconsistent and sometimes } \\
\text { duplicative. Moreover, the existence of two different statutes } \\
\text { separately criminalizing similar behavior is a potential problem, } \\
\text { especially since the penalties are different. They should be } \\
\text { harmonized. Sections } 23(1) \text { of the FSCA and } 46(2)(\mathrm{g}) \text { of the } \\
\text { Banking Act 2003, and Sections } 20(3) \text { of the FSCA and } 47 \text { of } \\
\text { the Banking Act are those that differ in this regard. }\end{array}$ \\
\hline 1(6). Arrangements for information sharing & $\begin{array}{l}\text { While provisions of the law enable the FSC to disclose } \\
\text { information to the FIU and to foreign supervisory authorities, no } \\
\text { processes have been established to date governing the exchange } \\
\text { of such information. While it is impractical to open } \\
\text { communications in this regard with foreign supervisory } \\
\text { authorities until the extent and nature of overseas operations of } \\
\text { international licensed financial institutions are known, the } \\
\text { process with the FIU should be accelerated to ensure it is in } \\
\text { place when licenses are issued. }\end{array}$ \\
\hline
\end{tabular}




\begin{tabular}{|c|c|}
\hline Reference Principle & Recommended Action \\
\hline 3. Licensing criteria & $\begin{array}{l}\text { The Banking Act } 2003 \text { sets out criteria for the definition of a } \\
\text { physical presence for international banks, and the FSC plans to } \\
\text { verify that international banks awarded a license are in } \\
\text { compliance with the provisions of the Act. The FSC should } \\
\text { approach the verification process both as a compliance exercise } \\
\text { and as a survey, the results of which should be analyzed for the } \\
\text { purpose of publishing a prudential statement on the FSC's } \\
\text { interpretation of "best practice" relating to physical presence. }\end{array}$ \\
\hline 3. Licensing criteria & $\begin{array}{l}\text { The FSC will be challenged to ensure that unregulated } \\
\text { institutions that may be operating a banking business are } \\
\text { identified and "contained." One aspect of this is to ensure that } \\
\text { those international institutions who have been operating under } \\
\text { the previous legislative regime and have indicated they will not } \\
\text { apply for a new license to conduct a banking business wind } \\
\text { down their banking business and surrender their license. A } \\
\text { comprehensive list of licensed financial institutions should be } \\
\text { published in a manner that is readily accessible to the public, } \\
\text { indicating that any other institutions purporting to be licensed } \\
\text { with the FSC are operating in contravention of existing banking } \\
\text { law. In the event the FSC becomes aware that an institution is } \\
\text { conducting a banking business without a license, it should post } \\
\text { warning notices, and where practicable, take legal action against } \\
\text { the institution. }\end{array}$ \\
\hline 4. Ownership & $\begin{array}{l}\text { The FSC is aware of the information required to assess a change } \\
\text { in control or significant change in the ownership structure of a } \\
\text { bank. However, there is no standardized medium through which } \\
\text { such changes can be reported. To facilitate the reporting of } \\
\text { these transactions and their analysis, the FSC should develop a } \\
\text { standardized form to ensure communication of essential } \\
\text { information. }\end{array}$ \\
\hline 6. Capital adequacy & $\begin{array}{l}\text { The FSC's prudential return for the reporting and assessment of } \\
\text { capital is satisfactory. However, there may be some confusion } \\
\text { or difference in interpretation of certain off-balance sheet line } \\
\text { items on the report. Definitions for off-balance sheet items are } \\
\text { warranted to assure greater consistency in reporting. }\end{array}$ \\
\hline 7. Credit policies & $\begin{array}{l}\text { There exists an appropriate legal framework for the FSC to } \\
\text { supervise credit risk management. To complement existing law, } \\
\text { the FSC should issue a prudential return requiring licensed } \\
\text { financial institutions to establish written credit and investment } \\
\text { policies, which govern the manner in which they manage risk, } \\
\text { maintain credit administration practices, monitor and report } \\
\text { exposures, and measure, control, ensure compliance with } \\
\text { restrictions on large exposures, and connected lending } \\
\text { relationships. }\end{array}$ \\
\hline 8. Loan evaluation and loan loss provisioning & $\begin{array}{l}\text { Prudential Statement 3-2004, which provides guidance to } \\
\text { licensed financial institutions on the classification of assets, } \\
\text { provisioning for loan loss reserves and nonaccrual assets, must } \\
\text { be amended to include classification and provisioning } \\
\text { requirements for off-balance sheet items. }\end{array}$ \\
\hline
\end{tabular}




\begin{tabular}{|c|c|}
\hline Reference Principle & Recommended Action \\
\hline 10. Connected lending & $\begin{array}{l}\text { The Banking Act } 2003 \text { needs to be amended to include a } \\
\text { comprehensive definition of "connected or related parties," and } \\
\text { to enable the FSC to use discretion in determining such } \\
\text { relationships. The present definition excludes business interests } \\
\text { of directors or shareholders and their families. The law also } \\
\text { does not permit the FSC to use judgment about the existence of } \\
\text { connections between the institution and other parties. Prudential } \\
\text { returns should provide information on large exposures and } \\
\text { connected lending relationships. }\end{array}$ \\
\hline 16. On-site and off-site supervision & $\begin{array}{l}\text { A legal framework exists that will enable the FSC to launch on- } \\
\text { site and off-site supervision functions. To do so, the FSC must } \\
\text { set a foundation. The foundation rests on a comprehensive } \\
\text { training program for supervision staff, including the senior } \\
\text { supervisor and the two junior supervisors. In addition, the FSC } \\
\text { must issue prudential returns in a number of critical areas of } \\
\text { banking activity and risk management to ensure that all licensed } \\
\text { financial institutions adopt international best practice and are } \\
\text { advised as to the nature of policy and practice that the FSC } \\
\text { expects. Supervisory tools, such as an examination manual and } \\
\text { examination report template also must be developed, together } \\
\text { with evaluation tools for such areas as credit, market and } \\
\text { liquidity risk. } \\
\text { Core Principles 7, 11, 12, 13, and } 14 \text { all reflect an acute need for } \\
\text { training of staff, issuance of prudential statements and the } \\
\text { development of supervisory tools such as inspection procedures } \\
\text { to build a competent on-site function. } \\
\text { Development of prudential returns, training in analysis of } \\
\text { financial institutions, and development of a technology platform } \\
\text { to facilitate analysis of data is required in the building of a } \\
\text { competent off-site function. } \\
\text { The FSC should concentrate its resources on these critical areas } \\
\text { in the near term, and delay implementation of a robust on-site } \\
\text { examination program until many of these critical necessities are } \\
\text { addressed. On-site examinations in the near term should be } \\
\text { limited to targeted areas of an institution, and should serve the } \\
\text { dual purpose of being a training exercise. Work of external } \\
\text { auditors, once certification is ratified, should complement } \\
\text { targeted examinations where the FSC has identified areas of } \\
\text { risk, noncompliance, or other areas of critical interest. }\end{array}$ \\
\hline
\end{tabular}




\begin{tabular}{|c|c|}
\hline Reference Principle & Recommended Action \\
\hline 18. Off-site supervision & $\begin{array}{l}\text { The FSC is authorized to apply certain sanctions against a } \\
\text { licensed financial institution in the event of noncompliance in } \\
\text { providing information such as required in a prudential return. } \\
\text { However, the law could be stronger in this regard, as } \\
\text { noncompliance is not a punishable offense at present, and fines } \\
\text { are not prescribed. Existing law should be amended to } \\
\text { strengthen the sanctions available to the FSC to facilitate } \\
\text { collection of accurate information in a timely manner. } \\
\text { An automated system should be developed to facilitate the } \\
\text { analysis of the international banking licensees. The FSC would } \\
\text { be able to compare performance more easily, and identify trends } \\
\text { and quantify differences in the banking business of this group. } \\
\text { Such information would be a valuable tool in policy } \\
\text { development and in developing supervisory strategies. The FSC } \\
\text { should seek technical assistance in developing such processes. }\end{array}$ \\
\hline 19. Validating supervisory information & $\begin{array}{l}\text { With the creation of the FSC, responsibility for registering } \\
\text { approved auditors has been transferred to the FSC. As many of } \\
\text { these auditors appear to have benefited from a "rubber stamp" } \\
\text { approval under past practice, a re-registration process is } \\
\text { warranted to update the current listing and enable the FSC to } \\
\text { perform appropriate due diligence. Equally important, the FSC } \\
\text { will be in a position to strengthen the ratification process where } \\
\text { weaknesses have been identified. }\end{array}$ \\
\hline 20. Consolidated supervision & $\begin{array}{l}\text { The FSC has virtually no knowledge of the overall structure of } \\
\text { international financial institutions, nor has it considered the } \\
\text { manner in which it will attempt to supervise material parts of } \\
\text { these groups or how to evaluate the risks they may pose to the } \\
\text { consolidated group. } \\
\text { However, now is the time for the FSC to seriously consider the } \\
\text { types of financial group structures that are desired for the Cook } \\
\text { Islands, and communicate this vision, through a prudential } \\
\text { statement, meetings with management and other media. The } \\
\text { prudential statement should define comprehensive supervision } \\
\text { on a consolidated basis, and the implications for licensees from } \\
\text { the standpoint of their organizational structure, operations, and } \\
\text { the quality and type of information that must be reported to the } \\
\text { FSC. } \\
\text { The FSC must have available financial and other information } \\
\text { from a supervisory perspective on Bank of the Cook Islands } \\
\text { Holding Corporation and any of its affiliates, both on a stand- } \\
\text { alone and consolidated basis. The FSC's supervision of Bank of } \\
\text { the Cook Islands, Ltd. otherwise is constrained, and its } \\
\text { supervision of the bank will not be on a comprehensive, } \\
\text { consolidated basis. }\end{array}$ \\
\hline
\end{tabular}




\begin{tabular}{|l|l|}
\hline \multicolumn{1}{|c|}{ Reference Principle } & \multicolumn{1}{|c|}{ Recommended Action } \\
\hline 21. Accounting standard & $\begin{array}{l}\text { The FSC should complement existing law pertaining to the } \\
\text { appointment of auditors and their reporting requirements by } \\
\text { issuing a prudential statement describing the criteria under } \\
\text { which it will approve auditors, and that financial statements of } \\
\text { licensees must be prepared in accordance with internationally } \\
\text { accepted accounting standards. }\end{array}$ \\
\hline 22. Remedial measures & $\begin{array}{l}\text { While the FSC is empowered to employ a wide array of } \\
\text { enforcement actions as part of its supervisory strategy related to } \\
\text { an institution, it lacks the power to require removal of directors } \\
\text { and officers for abuses of power or incompetence in the conduct } \\
\text { of their responsibilities. The FSC also does not have the } \\
\text { authority to impose fines. Existing laws should be amended to } \\
\text { empower the FSC to take these actions where warranted. }\end{array}$ \\
\hline $\begin{array}{l}\text { A prudential statement setting out a ladder of compliance, i.e., } \\
\text { explaining the various actions to licensees that the FSC may } \\
\text { employ also is advisable. }\end{array}$
\end{tabular}




\section{Detailed ASSESSMent Report on Anti-Money LAUNDERING ANd Combating THE FINANCING OF TERRORISM}

\section{A. General}

\section{Information and methodology used for the assessment}

14. A detailed assessment of the anti-money laundering (AML) and combating the financing of terrorism (CFT) regime of the Cook Islands was prepared by a team of assessors that included staff of the International Monetary Fund (IMF), an expert under the supervision of the IMF, and another expert not under the supervision of IMF who was selected from a roster of experts for the assessment of criminal law enforcement and nonprudentially regulated activities, provided by the Asia Pacific Group on Money Laundering. IMF staff and the expert under staff supervision reviewed the relevant AML/CFT laws and regulations, and supervisory and regulatory systems in place to deter money laundering (ML) and financing of terrorism (FT) among prudentially regulated financial institutions as well as with regard to nonprudentially regulated activities that are macroeconomically relevant, specifically trust and company service providers. The expert not under the supervision of IMF staff reviewed the regulatory systems in place for other nonprudentially regulated sectors, specifically money exchange and transmission services, as well as the capacity and implementation of criminal law enforcement systems.

15. A broad range of legal, regulatory, and supervisory materials were examined in the context of the assessment, including:

- Various statutes, including the Banking Act 2003 (BA), International Companies Act 1981-82 (ICA), Trustee Companies Act 1981-82 (TCA), the Financial Supervisory Commission Act 2003 (FSCA), the Financial Transactions Reporting Act 2003 (FTRA), the Proceeds of Crime Act 2003 (POCA), the Mutual Assistance in Criminal Matters Act 2003 (MACMA) and the Mutual Assistance in Criminal Matters Amendment Act 2003 (MACMAA), the Extradition Act 2003 (EA), the Criminal Procedure Amendment Act 2003 (CPAA), the United Nations (Security Council Resolutions) Act 2003 (UNSCRA), the Crimes Act 1969 (CA), the Criminal Procedure Act 1980-81 (CPA), etc.;

- $\quad$ Other enforceable legal materials, such as the set of specific regulations issued under the FTRA, covering respectively offering companies, forms, and customer identification, (a.k.a. the Financial Transactions Reporting Regulations 2004-FTRR) as well as the Extradition Regulations 2004 (ER), Proceeds of Crime (Border Currency Report Form) Regulations 2004 (PCR), International Companies (Evidence of Identity) Regulations 2004 (ICR), Qualifications for Compliance Officers pursuant to the FSC Act 2003, etc.; and

- $\quad$ Nonbinding legal materials, such as the Prudential Statements of the FSC. Since the draft Guidance Notes on the Prevention of Money Laundering and Terrorist 
Financing in the Cook Islands (March 2003) are not yet effective and are subject to further review, they were not considered in conducting the assessment.

16. The AML/CFT team consisted of Mr. Peter Csonka (Senior Counsel, LEG), Mr. Steven Gilbert (Consultant, MFD) and Mr. Simon Leung (Senior Inspector of Police, Hong Kong China), who conducted an assessment of the implementation of the criminal law enforcement elements of the AML/CFT Methodology as Independent AML/CFT Expert $(\mathrm{IAE})^{1}$ as well as of the arrangements applicable to money exchange and transmission services in the Cook Islands.

17. To conduct the assessment, the team visited Rarotonga (the main island of Cook Islands) from February 16 to February 27, 2004, and held discussions with officials of the Cook Islands Working Group on NCCT issues, the Ministry of Justice, the Crown Law Office (Solicitor-General), the Financial Supervisory Commission (FSC), the Financial Intelligence Unit (FIU), the Police, the Customs, as well as with representatives of the private sector, including the Law Society, the Trust Company Association, domestic banks, trust companies, external auditors, and a company providing money transmission services.

18. The assessment team is grateful for the high degree of cooperation and warm hospitality received from all the participants during its visit and especially expresses gratitude to the FSC and the FIU for the excellent organization of the visits and the substantial time they devoted to the completion of the self-assessment questionnaire.

19. The following categories of regulated financial institutions were included within the scope of the AML/CFT assessment: banks, insurance companies, and trustee companies.

\section{General situation of money laundering and financing of terrorism}

20. The Financial Intelligence Unit (FIU), the Cook Island Police (CIP), and the Crown Law Office (CLO) are the authorities directly involved in collecting intelligence, investigating, and prosecuting money-laundering related offenses. While the CIP and the $C L O$ are respectively the principal law enforcement and prosecution agency in the Cook Islands, Customs, Immigration, and Revenue Management departments also play minor investigative and prosecution roles in their respective field. They shall play the same role in combating the financing of terrorism when the proposed Suppression of Terrorist Financing Act is passed in the near future.

21. The general crime rate of the Cook Islands remains low. General crimes are burglary, petty theft and low-level fraud with an insignificant amount of property involved. There is no evidence suggesting that the Cook Islands has problems of any major organized

\footnotetext{
${ }^{1}$ Portions of the assessment attributable to the IAE are shown in italicized text throughout this report.
} 
crime, drug trafficking or serious fraud, crimes which would generate large amount of revenue and create a domestic demand of money laundering services.

22. While the risk of domestic money laundering is small, there is a potentially significant risk of the Cook Islands offshore banking sector and trustee companies being abused by criminal elements.

23. There is yet no successful investigation and prosecution of money laundering in the Cook Islands and thus there are no statistical data on the estimated volume of proceeds of crime. It is therefore not possible to estimate the amount of money laundering, if any, which might take place in or through the Cook Islands. The insignificant number of suspicious transactions reports made to the FIU is also insufficient to indicate any particular money laundering trend or typology.

\section{Overview of measures to prevent money laundering and terrorism financing}

24. The Cook Islands remains on the FATF's list of Non-Cooperative Countries and Territories (NCCT) since June 2000. FATF's concerns included that the Cook Islands Government (CIG) held no relevant information on approximately 1,200 international companies it had registered and that the country licensed seven offshore banks that took deposits from the public, yet were not required to identify customers, nor keep records. Excessive secrecy provisions guarded against the disclosure of bank records and relevant information about the international companies. Further, the International Companies Act of 1981 (ICA), permitted issuance of bearer shares and the marketing of shelf companies. The ICA also prohibited public access to registers of corporate directors or managers or the disclosure of beneficial owners. While corporate directors were not required to be residents, companies had to maintain a registered office and company secretary in the Cook Islands and file annual reports, but were not required to have their accounts audited.

25. The Cook Islands has enacted several legislative reforms to address the deficiencies identified by the FATF. The first set of measures were taken in August 2000, when the Cook Islands enacted the Money Laundering Prevention Act 2000 (MLPA), but given continued FATF concerns over the adequacy of the AML framework, an entirely new AML-suite came into force in June 2003, superceding the previous legislation and regulations. The new AML suite included new acts on proceeds of crime, mutual legal assistance, extradition, and financial transactions reporting. It has also amended the Crimes Act 1969 (CA) to introduce a new ML offense through Sections 280A and 280B. The new ML offense extends to all predicate offenses that are "serious offenses" and applies to both physical and corporate persons. "Serious crimes" were defined by threshold, as a result of which any offense punishable under Cook Islands law by imprisonment of not less than 12 months or a fine of more than $\$ N Z 5,000$, whether committed in the country or overseas, so qualifies. However, at present FT is not criminalized, and it is not a predicate offense for ML. A new Banking Act was also enacted in 2003. 
26. Under the Proceeds of Crimes Act 2003 (POCA), provisions were made to the effect that tainted property and benefits derived from crime can be recovered through two different types of legal action, i.e., forfeiture orders and pecuniary penalty orders. Both are discretionary criminal penalties and require conviction of a serious offense. Forfeiture can be applied also against tainted property where the accused has absconded or died. Under the POCA, law enforcement authorities can use production orders, monitoring orders and search warrants for tracing assets, and seizure and restraining orders can be used to secure them.

27. As part of the 2003 AML-suite, the Financial Transactions Reporting Act 2003 (FTRA) redefined obligations and procedures related to customer identification, recordkeeping, internal controls and reporting of suspicious or other types of transactions. It has also reorganized the supervisory structure, by allocating compliance checking functions for licensed entities to the Financial Supervisory Commission (FSC) and set up an independent administrative-type FIU, with responsibility for the supervision of non-licensed entities as well as the collection, analysis, and dissemination of financial intelligence. Under Sections 10 and 11 of the FTRA, a broad range of financial institutions are required to submit MLrelated reports to the FIU on suspicious transactions and cash or electronic transactions above $\$ N Z 10,000$. The FIU has the authority to require reporting parties to supplement reports and has broad powers to obtain relevant information needed to combat ML, but it does not have FT-related functions at present. The FIU has been also charged with the exchange information with counterpart FIUs and training. Its Egmont Group membership is expected to be granted in June 2004.

28. The Cook Islands is not a party to the Vienna Convention and it has not signed, nor ratified the Palermo Convention. The Cook Islands signed the UN International Convention for the Suppression of the Financing of Terrorism on December 24, 2001, but has not ratified it yet. The Cook Islands enacted the UNSCRA to give effect to UN Security Council Resolutions on FT, including Resolution 1373, but has not yet issued any implementing regulations under the Act.

29. The Mutual Assistance in Criminal Matters Act 2003 (MACMA) and the POCA made provisions for enabling the Cook Islands to provide a broad range of types of assistance without formal treaty or similar arrangements subject to dual criminality. The Extradition Act 2003 (EA) sets forth similar provisions to enable extradition, though the absence of criminalization of FT prevents the Cook Islands from extraditing persons sought for FT. This shortcoming has already been identified and the authorities are planning to correct with the proposed draft Terrorism Suppression Bill.

30. The Cook Islands is a member of the Asia/Pacific Group on Money Laundering and was subject to a mutual evaluations conducted by that Group jointly with the Offshore Group of Banking Supervisors in October 2001. 


\section{B. Detailed Assessment}

31. The following detailed assessment was conducted using the October 11, 2002 version of Methodology for assessing compliance with the AML/CFT international standard, i.e., criteria issued by the Financial Action Task Force (FATF) 40+8 Recommendations (the Methodology).

\section{Table 4. Detailed Assessment of Criminal Justice Measures and International Cooperation}

\section{I-Criminalization of ML and FT}

\section{(compliance with criteria 1-6)}

\section{Description}

\section{Conventions}

The Cook Islands is not a party to the UN International Convention for the Suppression of the Financing of Terrorism, which it signed on December 24, 2001, but has not yet ratified. The ratification is due to occur once Parliament adopts a draft Terrorism Suppression Bill, which at the time of the mission was under preparation at the Crown Law Office on the basis of the regional "Counter Terrorism and Transnational Organized Crime Model Provision 2003," a model law provided by the Pacific Islands Forum Secretariat. The Crown Law Office intends to finalize drafting work on this draft Terrorism Suppression Bill by March 2004 and table at the next Parliament session, also scheduled for March 2004.

The Cook Islands has neither signed, nor ratified the UN Convention against Transnational Organized Crime (Palermo Convention) or the United Nations Convention on Illicit Drugs and Psychotropic Substances (Vienna Convention). The authorities advised that participation in these conventions was approved by the Cook Islands Government (CIG) and that the necessary instruments of ratification or accession will be prepared. Pending ratification, the enabling legislation has been largely put in place with regard to the requirements of the Palermo Convention.

The Cook Islands has not yet implemented the United Nations Security Council Resolutions (SCRs) 1267, 1269, 1333, 1373, and 1390, although it passed legislation on April 9, 2003 - the United Nations (Security Council Resolutions) Act 2003 - that allows the CIG to give effect by way of Order in Executive Council to important Security Council Resolutions concerning threats to the peace, breaches of the peace, and acts of aggression. This Act authorizes the CIG to issue regulations "as it appears to be necessary or expedient" to effectively apply the measures required of UN member States by SCRs, which include the SCRs on measures to counter terrorism. However, the CIG has not yet issued any regulations under this Act, mainly because it plans to cover the requirements set forth by the UN SCRs through the planned CFT legislation.

\section{Criminalization of Money Laundering}

The Cook Islands has criminalized money laundering through Section 280A of the Crimes Act 1969, which set forth several different offenses. The principal ML offense is at Article 280A, which makes it a crime to:

- acquire, possess or use property knowing or having reason to believe that it is derived directly or indirectly from a serious offense;

- convert or transfer such property directly or indirectly from a [serious offense] with the aim of concealing or disguising the illicit origin of that property, or aiding any person involved in the commission of the offense to evade the legal consequences thereof;

- conceal or disguise the true nature, origin, location, disposition, movement or ownership of the 
property derived directly or indirectly from a [serious offense]; and

- $\quad$ render assistance to another person for any of the above.

Predicate offenses for ML are "serious offenses," which are defined by threshold. According to Section 280, a "serious offense" is:

- $\quad$ an act or omission that constitutes an offense against a law of the Cook Islands punishable by imprisonment for not less than 12 months or the imposition of a fine of more than \$NZ 5,000; or

- $\quad$ an act or omission that constitutes an offense against the law of another country that, had that act or omission occurred in the Cook Islands, it would have constituted an offense against the law of the Cook Islands punishable by imprisonment for not less than 12 months or the imposition of a fine of more than \$NZ 5,000.

As a result of this threshold, over 200 offenses qualify as "serious" and thus as predicate offenses for ML. The list includes a large number of potential proceeds-generating offenses that are set forth either by the Crimes Act 1969 and its subsequent amendments, or by other primary legislation (e.g., the Secret Commissions Act 199495, the Income Tax Act 1997 or the Narcotics Act 1965). The Crimes Act 1969 contains a wide range of serious offenses such as:

- $\quad$ Dealing in persons (Section 109);

- Bribery and corruption" (Sections 110-117);

- $\quad$ Participating in organized crime group (Section 109A);

- $\quad$ Smuggling migrants (Section 109 C);

- $\quad$ Trafficking in people (Section 109 D);

- $\quad$ Prostitution (Section 163);

- $\quad$ Kidnapping (Section 231);

- $\quad$ Theft (Sections 242-248);

- Criminal breach of trust (Section 252);

- $\quad$ Robbery (Section 256);

- Extortion by certain threats (Section 260);

- $\quad$ False pretences (Sections 268-269);

- $\quad$ Fraud and false accounting (Sections 273-276);

- Conspiracy to commit offense (Section 333); and

- Market manipulation, false trading and market rigging (Sections 339-340).

Other statutes also establish serious criminal offenses, such as the Secret Commissions Act 1994-95 that defines various acts of corruption or the Narcotics Act 1965 that criminalizes drug trafficking. Criminal offenses committed overseas may also qualify as predicate offenses provided they meet the threshold requirement and that they would constitute offenses in the Cook Islands as well (dual criminality).

Penalties for ML vary depending on the defendant. Physical persons may be convicted to a term of imprisonment of up to five years or a fine of up to $\$ N Z 50,000$, and the authorities advised that restitution would be applicable as well under the Crimes Act 1969. Forfeiture and pecuniary penalty orders are also applicable under the POCA. Neither the POCA, nor the Crimes Act 1969 provides that those convicted of ML may also have professional licenses revoked or barred from exercising certain professional activities. Legal persons convicted of ML would face fines of up to $\$ N Z 250,000$, i.e., five times the amount of the fine for physical persons and the forfeiture and pecuniary penalty orders under the POCA are applicable. Again, neither of the two statutes allows the winding up of companies as a criminal penalty in ML cases.

Conviction on a predicate offense is not necessary for a ML conviction as Section 280A expressly provides that 
"any person may be convicted of a money laundering offense under this section notwithstanding the absence of a conviction in respect of a crime which generated the proceeds alleged to have been laundered." Since the ML offense is largely untested in judicial practice, it is unclear at this stage what evidence would be necessary to prove the link between the ML and the predicate offense for a conviction to occur. The authorities believe that the prosecution would only need to establish that the source of the funds was some sort of criminal activity, without specifically designating the offense from which the proceeds originated.

The language of the ML provision does not make it explicit whether persons may be convicted of both ML and a predicate offense (self-laundering), but the authorities advised that this was their intention when drafting Article 280A. The mission had the impression that the current definition was more akin to a third-party ML offense.

The Crimes Act 1969 also contains an ancillary ML offense at Section 280B, which makes it an offense to disclose "to another person information or other matter likely to prejudice any investigation of an offense or possible offense of ML." It is a defense for the person disclosing the information to prove that he/she did not know, and had no reasonable grounds for suspecting that the disclosure was likely to prejudice the investigation, provided the disclosure does not fall within the person's duties. The penalties for this "tipping off" offense are identical to those foreseen for the principal ML offense, but can also be combined.

In addition to the criminal ML offenses set forth by Sections 280A and 280B of the Crimes Act 1969, violations of the various obligations under the Financial Transactions Reporting Act 2003, also constitute criminal offenses punishable by a fine up to $\$ N Z 10,000$ or imprisonment.

\section{Criminalization of FT}

The Cook Islands has not yet criminalized FT, nor ratified the International Convention for the Suppression of the Financing of Terrorism (ICSFT). A draft Terrorism Suppression Bill is currently under preparation on the basis of the "Counter Terrorism and Transnational Organized Crime Model Provision 2003," a model law provided by the Pacific Islands Forum Secretariat.

\section{Scienter}

In the Cook Islands, the ML offense applies to those who engage in ML "knowingly" or on a "reasonable suspicion" basis. Willful blindness is not enough for meeting this knowledge standard. The required knowledge, intent or purpose elements of the ML offenses may be inferred from objective factual circumstances. Legal entities also have criminal liability in Cook Islands, so the ML offenses extend to any entity whether natural or legal. The definition of "person" under the Interpretation Act 1924 refers to both natural and corporate persons, which encompasses any companies or foundations. Further, Section $280 \mathrm{~A}(5)$ specifically sets out a penalty for a "person which is a body corporate."

\section{Adequacy of Legal Means and Resources}

The AML-related laws enacted by the Cook Islands have been largely inspired by the model provisions of international organizations or the laws of other countries. The Cook Islands has virtually all the necessary legal means to prevent systemic ML. Law enforcement agencies will be able to use these powers in combating the financing of terrorism as well when the FT Act is passed in the near future. The current technical and human resources, however, do not meet the requirements of the new legislation.

In implementing AML-related laws, the FSC and FIU have been actively engaged in establishing the ML reporting system and maintaining close liaison with financial institutions. On the law enforcement side, however, the CLO, CIP, Immigration, and Customs are not fully familiar with the new AML related legislation. The agencies are not aware that there is wide range of investigative power available under the new legislation.

Both the supervisory authorities and law enforcement agencies are understaffed 
Analysis of Effectiveness

The Cook Islands has not yet ratified any international treaty on ML or FT, though it has put it place much of the required implementing legislation for the Palermo Convention (for example, it criminalized various bribery offenses and participation in organized criminal groups). The similar requirements of the Vienna Convention regarding the ML-offense and confiscation are also largely met by the current legislation (POCA), while the Narcotics Act 1965 would benefit from a consequential revision to satisfy the Convention's other requirements. Notwithstanding the existence of implementing legislation, the mission regards the lack of ratification of international treaties as a significant shortcoming, e.g., because it prevents the Cook Islands from participating in international cooperation set up under these treaties. In addition, the CIG has not implemented the UN SCRs on FT either, in particular SCR 1373, as it has not issued the necessary regulations under the United Nations (Security Council Resolutions) Act 2003. As FT has not been criminalized yet, this is also considered by the mission as a major issue for compliance with the international standards.

As no ML charge was laid by the prosecution authorities in the Cook Islands up to date, it is difficult to assess the practical effectiveness of the current ML provision. The Cook Islands criminalized ML for the first time in 2000 by the Money Laundering Prevention Act 2000, which was later repealed, but no prosecution was brought under this earlier statute either. The repealed and current ML provisions are broadly similar. The disappointing prosecution results do not seem to be linked to the definition of the ML, which is in line with the latest international standards, but rather to an obvious lack of focus on proceeds in criminal investigations combined with a lack of familiarity with the ML offense. The only serious deficiency of the current ML provision is that the scope of "serious offense" does not extend to FT and related terrorism offenses as these are not yet criminalized. The authorities are aware of this deficiency and are working towards an early enactment of the necessary legislation.

In addition, there are several areas, where the mission believes that the legal regime of the ML offense could be made more robust and these amendments could help the process of implementation. The mission suggests in particular to:

- criminalize expressly the laundering of one's own proceeds in Section 280A;

- include "willful blindness" among the knowledge standards;

- include additional penalties for legal entities or professionals engaged in ML or FT, such as withdrawal of license or bar from exercising a professional activity; and

- $\quad$ enable that the penalties foreseen for the ML offense under Section 280A may be combined.

The FT is not yet listed as a serious offense in the Cook Islands legislation and is thus not covered by the current AML legal regime. It is however reasonable to presume that FT will be incorporated into the current AML system. In respect of AML legislation, the Cook Islands drew inspiration from the model provisions of international organizations, such as the IMF and from the domestic laws of various countries, principally of New Zealand. Hence, the AML legal regime of Cook Islands is comprehensive. It provides law enforcement agencies with sufficient powers to investigate and prosecute ML offenses. However, both the investigation and prosecution agencies are unfamiliar the new AML legislation and still put their main focus on the arrest and prosecution of principal offenders but pay little attention to the possibility of restraining and forfeiting the proceeds of crime.

High Court Judges of Cook Islands are stand-in from New Zealand Judiciary and are not based on the Islands. Each judge will stay on the Island and hear cases for two weeks by turn. Although it is not yet tested, the Solicitor-General advised that phone conferences with judges residing in New Zealand could be arranged by the Cook Islands Court Registrar if the CLO needed to apply urgently for a court order under the POCA. The signed order would be faxed from New Zealand to the Cook Islands. This arrangement is sensible and meets the need where urgent action is required.

Justices of Peace (JPS), who sit at the low-level courts of the Cook Islands and juries at the High Court, are laymen. It is anticipated that they would have certain difficulties to understand the ML related laws. In respect of 
the High Court judges of the Cook Islands, they are legally qualified judges of New Zealand and thus their competency to try the ML cases is not in doubt. As there is yet no prosecution of ML case tried in courts of the Cook Islands, it would be inappropriate to speculate as to any potential difficulties in prosecuting the ML offense and make comment on the sentence for convicted defendants.

Recommendations and Comments

- $\quad$ Ratify the relevant international treaties on ML and FT, such as Vienna and Palermo Conventions and the ICSFT;

- Implement the UN SCRs on FT;

- Criminalize FT as a matter of priority and include it among "serious offenses" so that it is a predicate offense for ML;

- Consider a review of the ML offense to include the above elements;

- $\quad$ Provide immediate training for ML investigators and prosecutors in the new AML legislation and develop skills and techniques of financial investigation;

- Provide training to the JPs and laymen in the new AML legislation and make such training also available to New Zealand judges with regard to Cook Islands legislation;

- Set up the forfeiture fund provided for by Section 100 of the POCA and use the additional resources for providing training to investigators and prosecutors; It would motivate the law enforcement agency to pursue the proceeds of crime.

Implications for compliance with FATF Recommendations 1, 4, 5, SR I, SR II

FATF 1 - Noncompliant, as the Vienna Convention is not yet ratified.

FATF 4 - Compliant.

FATF 5 - Compliant.

SR I - Noncompliant as the UN ICSFT is not yet ratified and the UN SCRs are not implemented.

SR II - Noncompliant, as FT is not criminalized.

\section{II-Confiscation of proceeds of crime or property used to finance terrorism}

(compliance with criteria 7-16)

\section{Description}

\section{Confiscation}

The confiscation regime of the Cook Islands is mainly governed by Sections 11-34 of the POCA, although some crime-specific provisions exist in other statutes. For example, Section 18 of the Narcotics Act 1965 contains a forfeiture provision, which is only available under that statute. Generally confiscation in the Cook Islands is based on two different types of legal action, one called "forfeiture order" and another called "pecuniary penalty order."

Forfeiture orders

Criminal forfeiture orders aim at recovering "tainted property," defined by Section 3 of the POCA as covering:

- $\quad$ property that is used in or in connection with the commission of a serious offense whether situated in the Cook Islands or elsewhere (actual instrumentalities);

- property that is intended to be used in or in connection with the commission of a serious offense whether situated in the Cook Islands or elsewhere (intended instrumentalities);

- $\quad$ proceeds of a serious offense, that is property into which any property derived or realized directly from a serious offense was later successfully converted, transformed, or intermingled, as well as income, capital or other economic gains derived or realized from such property at any time since the commission of the offense, whether the property is situated on the Cook Islands or elsewhere.

Section 3 also clarifies that "property" includes money and all other property, real or personal, whether situated in the Cook Islands or elsewhere, including an enforceable right of action and other intangible or incorporeal property. 
Forfeiture is a discretionary criminal penalty and requires conviction of a serious offense. Under Section 11 of the POCA, if a person is convicted of a serious offense, the Solicitor-General may apply to the Court for a forfeiture order within a period of 6 years following the day when the person was convicted. The application for the forfeiture order is made against the "tainted property," whether the property is situated in the Cook Islands or elsewhere, or the proceeds of that offense. Under Section 12 of the POCA, the Solicitor-General must first issue notice of such application being made and then the Court determines, upon the application of the SolicitorGeneral, whether the property is "tainted" or not. In determining the "tainted" character of the property, the Court may draw inferences from the fact that the property was found in the offender's possession, or under his/her control, or was used for the commission of the offense, etc. Under Section 17 of the POCA, if the Court determines that the property is tainted, it orders that it be forfeited to the Crown. If the Court orders that property or money be forfeited, it has to determine the value of the forfeited property and may give directions to give effect to the order.

Where tainted property cannot be found or is located outside the Cook Islands, the Court may order the person to pay to the Crown an amount equal to the value of the property. An amount payable to the Crown under such a value-based forfeiture order is regarded as a civil debt by the person to the Crown and can be enforced as if it were an order made in civil proceedings. Section 16 of the POCA excludes the application of forfeiture to native freehold land, the extent of which is said to be quite significant in the Cook Islands. The Court in such cases could only forfeit movable property.

Pecuniary penalty orders

The pecuniary penalty order aims at recovering, on conviction, the "benefits" derived from a serious offense and the application for such order is made by the Solicitor-General against the defendant who benefited from the offense. Benefit is defined at Section 4 of the POCA as any payment or reward received in connection with, or any pecuniary advantage derived from, the commission of the offense. Section 27 of the POCA sets forth further rules for determining the benefit and assessing its value. These rules provide that if a person obtains tainted property, the person's benefit is the value of the property so obtained. If a person derives an advantage as a result of, or in connection, with committing a serious offense, the person's advantage is taken to be a sum of money equal to the value of the advantage so derived. If the Court is satisfied that the defendant has benefited from the offense, it orders him/her to pay a sum equal to the value of the benefit. The conditions of application and enforcement of pecuniary penalty orders are otherwise similar to those of forfeiture orders, but Sections 28-30 of the POCA specifically stipulate the methods of calculating the amount of property that can be realized.

\section{Confiscation without criminal conviction}

Section 21 of the POCA allows an application to be made to the Court for a forfeiture order against tainted property where the accused has absconded. Section 15 (2) clarifies that a person is taken to have absconded in connection with an offense if reasonable attempts to arrest the person under a warrant have been unsuccessful during a period of 6 months starting on the day that the warrant was issued. The fact that the defendant absconded does not dispense with the obligation of the Solicitor-General to give reasonable written notice of the application for forfeiture to any person who appears to have an interest in the property.

This provision of the POCA also allows for the forfeiture of tainted property where the defendant has died after the issue of the warrant.

\section{Property of Criminal Organizations}

There is no specific provision mandating the confiscation of property that belongs to organizations found to be primarily criminal in nature. However, the participation in an organized criminal group is an offense under Section 109A of the CA and as the penalty for this offense is a term of imprisonment not exceeding five years, it qualifies as a "serious offense." In accord with Section 11 of the POCA, forfeiture is therefore applicable to any person convicted of participation in an organized criminal group, but as the main forfeiture provision is 
discretionary, its application to organized crime participants is so as well. In addition, this provision does not address the forfeiture of the organized criminal group's property itself.

In making a pecuniary penalty order, Section 32 of the POCA allows the Court to "lift the corporate veil" so as to assess the value of the benefits derived by a person from a serious offense. It also provides that the Court may order the investigation and inspection of the books of a company when deciding whether that company has a direct or indirect interest in the property. The Court can make an order declaring the property of the company as available to satisfy a pecuniary penalty order against the person.

\section{Provisional measures}

Search and seizure

The POCA regulates search and seizure of proceeds in relation to serious offenses and provides for search warrants in two different situations:

- $\quad$ Search for tainted property (Sections 35-36);

- $\quad$ Search for property-tracking documents (Section 85).

Sections 35 and 36 empower police officers to apply to the Court or Registrar of the High Court for a warrant to search land or premises for "tainted property." The Police can seize tainted property if they have reasonable grounds for believing that it is tainted property or that it can afford evidence about the commission of a serious offense in the Cook Islands or to prevent it from being concealed or destroyed, etc. The Police have to specify the offense for which the property is tainted within 48 hours after the property was seized, failing which the property has to be returned to the person from whose possession it was seized. In order to retain seized property, a restraining order must be made against that property. Under Section 48 of the POCA, the Solicitor-General can apply for a restraining order against property held by a defendant or by a person other than a defendant and this order may be made ex parte.

Section 85 empowers police officers to apply for a warrant to search premises for a "property-tracking" document related to a serious offense. Section 85 (2) clarifies that any document relevant to identifying, locating, or quantifying the property subject to the effective control of person convicted or suspected of having committed a serious offense, where there are grounds for believing that he/she derived a benefit from that offense, is to be treated as a property-tracking document.

Moreover, the CPA regulates general search and seizure powers. Sections 96 and 97 authorize any constable to search premises and seize objects, evidence or instrumentalities of any offense punishable by imprisonment. The seized object, etc. is retained under the custody of the constable until it is disposed of by Court order, including its forfeiture. If no proceedings have been brought three months after the date of seizure, any person claiming to be entitled to it may apply for its release.

Restraining orders

Section 50 of the POCA provides for the conditions under which the Court may issue a restraining order. These conditions include that:

- $\quad$ the defendant has been convicted, has been charged or will be charged with a serious offense within 48 hours;

- if the defendant has not yet been convicted, there are reasonable grounds for believing that the defendant committed the offense (Section 48 (3) suggests that the suspected offense must have been committed within the 6 years preceding the Solicitor-General's application or since the application was made);

- there are reasonable grounds for believing that the defendant's property is tainted or he/she derived a 
benefit directly or indirectly from the commission of the offense; and

- $\quad$ if the property is that of another person, there are reasonable grounds for believing that the property is tainted or is subject to the effective control of the defendant.

The Solicitor-General must give reasonable notice about his/her application for a restraining order, unless he/she has reasons not to do so, in which case the Court may issue a restraining order valid for a maximum period of 14 days. Otherwise, the restraining order will be valid for a period of six months and can be renewed as long as necessary in order to enable a forfeiture or pecuniary penalty order to be made. The Court may appoint an Administrator to take custody of the restrained property and direct him/her to satisfy the pecuniary penalty order by a payment to the Crown out of the property restrained. Once the respective periods of appeal against the defendant's conviction, against the restraining order itself or against the pecuniary penalty order have expired, the Administrator can take action to sell the property.

\section{Powers to identify and trace}

Law enforcement authorities in the Cook Islands, including the Police and the Solicitor-General, can use production and monitoring orders as well as the search (and seizure) power to identify and trace proceeds. Production orders are regulated under Sections 78 to 86 of the POCA and monitoring orders under Sections 87 to 92 of same the Act. The search (and seizure) power is available under the POCA, the CPA and the Narcotics Act 1965.

\section{Production orders}

Under Section 79 of the POCA, police officers can apply to a judge for a production order-an order to make a document available for inspection - in respect of any person who may be in possession or control of a propertytracking document. The application may be made ex parte. The production order compels a person to produce to a police officer at a specified time and place any specific property-tracking documents or any documents of that kind in this person's possession or control. Property-tracking documents have the same meaning in this context as defined for search under Section 85.

In case the document is a computer file, the production order may also compel persons to give the police officer access to the computer on which the document is held and provide him/her with any password and computer software necessary to access it. Once produced to the police officer, he/she can inspect it, take extracts from it, print it, make copies of it or keep it. While the document cannot be used as evidence against the person who produced it in any criminal proceedings, except for failure to comply with the production order, the fact that the information would incriminate him/her or would constitute a breach of an obligation not to disclose it, is not accepted as excuse (Section $82(2))$.

Monitoring orders

Under Section 87-88 of the POCA, the Solicitor-General can apply to the Court for a monitoring order requiring that a financial institution provide information about transactions conducted during a particular period through an account held by a particular person with the financial institution. The order may be made for a maximum period of six months.

Search warrants

See description above under Provisional Measures.

Disclosure of information held by Government Departments

Pursuant to Sections 93 and 94, a Government department or statutory body can be directed by the SolicitorGeneral to give or disclose any document or information that is relevant to establishing whether a serious offense 
has been or is being committed or to the making of orders for forfeiture, pecuniary penalty, search or seizure under Parts 2 and 3 of the POCA.

FIU powers

Under the FTRA, the FIU has comprehensive powers to assist in identifying and tracing property. For example, it may request information from any law enforcement agency and supervisory authority for the purposes of the FTRA; it may send information to the appropriate law enforcement agency; it can enter into agreements or arrangements with institutions or agencies with similar powers and duties, of foreign jurisdictions regarding the exchange of information; when it receives a suspicious transaction report, it can request further information from the financial institution reporting it and provide the information to the law enforcement agency, etc.

\section{Rights of bona fide third parties}

The POCA provides protections for the rights of bona fide third parties in respect of any confiscated or forfeited property. For example, under Section 12 of the Act, where the Solicitor-General applies for a forfeiture order, the Solicitor-General must give reasonable written notice to any other person whom the Solicitor-General believes may have an interest in the property. The Court may also direct the Solicitor-General to publish notice of the application in the newspapers.

Section 20 of the POCA allows third parties who claim to have an interest in the property to apply to the Court declaring the nature, extent, and value of the person's interest if the Court is satisfied that the applicant was not in any way involved in the committing of the offense and the applicant acquired the interest at the time or after the offense was committed, for sufficient consideration and without knowing that the property was at the time, tainted property. If the forfeiture order has already been made against property, a person who claims an interest in the property may apply, within six months starting on the day when the order is made, to the Court for order declaring the nature, extent and value of the person's interest. If such order is made by the Court, the property is returned to the person claiming interest in it, or if has been disposed of, an amount equal to the value must be paid.

Under Sections 49 and 62 of the POCA, the Court must require the Solicitor-General to give reasonable written notice to any person who may have an interest in the property, and the Court may hear that person before issuing a restraining order or an interim restraining order. If the Solicitor-General requests that no written notice be given, the Court can grant the application but the order has effect for 14 days only. After 14 days, the SolicitorGeneral can apply for an extension of that period; however, the Court must not consider the application without requiring reasonable written notice to be given to any person who may have an interest in the property.

\section{Authority to void contracts}

Section 18 of the POCA provides for the voiding of contracts that aim at frustrating a forfeiture order. Accordingly, a Court may, before making a forfeiture order under Section 17, set aside any conveyance or transfer of property that occurred after the seizure of the property or service of the notice of application on persons affected by the order under Section 12, unless the transfer was for valuable consideration to a person acting in good faith and without notice.

Moreover, the authorities referred to the Illegal Contracts Act 1987, which may also be invoked for voiding contracts. This statutes defines illegal contracts as "any contract that is illegal at law or in equity," whether the illegality arises from the creation or performance of the contract and includes a contract which contains an illegal provision, whether the provision is severable or not."

\section{Statistics}

There is no designated agency either overseeing the forfeiture program or keeping relevant statistics. In fact, there is no successful or ongoing ML/FT investigation. Hence, relevant statistics do not exist. 


\section{Training}

Formal AML/CFT training in matters related to the freezing, seizure and confiscation of property is not available. Some training on an ad hoc basis is provided and funded by donor agencies on a regional level. The head of the FIU has attended various workshop organized by AML regional body while the Intelligence officer of the FIU has been attached to the FIU of New Zealand Police for training on three occasions. Staff of the SC and CIP have also attended various workshops on AML/CFT.

\section{Statistics on FT forfeitures}

FT is not yet an offense in the Cook Islands and thus the relevant statistics are not available. Once the CFT legislation is available, the relevant statistics should be prepared by the designated agency.

\section{Freezing for FT}

There exists no legislation specifically providing for the freezing of funds or other property of terrorists or persons associated with terrorists, and only framework legislation (the UNSCRA) was enacted for giving effect to the relevant UN SCRs. As the CIG has not yet issued any implementing regulations under this Act and FT is not a criminal offense yet, the authorities are currently not in a position to freeze without delay funds or other property of terrorists, those who finance terrorism and terrorist organizations as required by the UN SCRs relating to the prevention and suppression of FT. The mission notes that the CIG plans to cover the requirements set forth by these UN SCRs through the planned CFT legislation.

\section{Procedures for disseminating freeze lists}

There exists no legislation specifically providing for freezing funds or other property of terrorists or persons associated with terrorists, and the mission understands that $\mathrm{UN}$ terrorist watch-lists are not circulated by the Cook Islands authorities to financial institutions, nor is there any process for updating them about possible changes.

\section{Asset Forfeiture Fund}

Section 100 of the POCA provides for a fund to be known as the Confiscated Assets Fund. Section 100 (2) provides that the following be paid into the Fund: money paid to the Crown instead of a forfeiture order; money paid under a pecuniary penalty order; and money paid by a foreign jurisdiction in respect of confiscated assets. The Financial Secretary with the approval of the Minister of Finance may authorize payments to be made out of the Fund for purposes related to law enforcement; to satisfy an obligation of the Crown to a foreign jurisdiction in respect of confiscated assets; to meet the remuneration and expenses of the Administrator; and to cover costs associated with the administration of the Fund.

\section{Asset Sharing}

Section 36 (2) of MACMA provides that where the Attorney-General requests a foreign country to make arrangements for the enforcement of a forfeiture order or pecuniary penalty order, the Attorney-General may enter an arrangement with the foreign county to share the amount forfeited or paid. Further, Section 40 (3) of MACMA provides that where a foreign forfeiture order or pecuniary penalty order is registered in the Court, the Attorney-General may enter an arrangement with a foreign country to share with that country the amount forfeited or paid.

Analysis of Effectiveness

As a result of the enactment of the POCA, the legal provisions regulating the confiscation regime (criminal forfeiture and pecuniary penalty orders) and provisional measures are comprehensive and broadly conform to the international standards. However as no property was ever restrained, seized or forfeited under the current 
legislation, the working of this regime has yet to be tested in practice. This obviously makes it difficult for the mission to assess its actual effectiveness. However, the fact that the current confiscation regime is discretionary may explain, at least partly, why it is not implemented in practice. In addition, the reasons for the current distinction made in the POCA between two different classes of legal action, forfeiture orders on the one hand and pecuniary penalty orders on the other, are unclear, in particular in light of the broad definition of tainted property. The mission considers that given the significant potential for overlap, unless there are compelling policy reasons, it is worth considering whether they should be maintained separately. One possibility would be to extend the notion of tainted property to "benefits."

As practice develops, the authorities will be able to assess whether the current legal regime enables the effective confiscation of criminal proceeds and other tainted property. Besides making criminal forfeiture mandatory, they may wish to consider further extending the current regime by introducing civil forfeiture, i.e., forfeiture that is not based on criminal conviction and involves a partial or total reversal of burden of proof as to the origin of the assets. In this regime, proceedings are brought against tainted property usually in civil proceedings and the standard of proof is also one of civil law (balance of probabilities).

The powers available to law enforcement authorities for tracing assets, i.e., production orders, monitoring orders and search warrants, seem to provide a sufficient basis for carrying out investigations without any major impediment. Secrecy obligations are overridden by these powers, even if a general provision such as Section $35-$ 36 of the FTRA 2003 does not exist under the POCA. The relevant provisions of the POCA for tracing assets have so far not been tested in practice either. One of the reasons is that law enforcement authorities are not familiar with this statute and seem to prefer using a general search warrant rather than one of the new powers.

Because there have been no ML investigations or prosecutions, no related statistics are yet maintained. Given the central position of the Crown Law Office in administering the POCA, it would seem to be the best placed public authority to collect ML and FT-related statistical data (investigations, prosecutions and related judicial orders) as practice develops.

The availability of AML/CFT training is limited. Presently, no investigator in the CIP has received training of this sort.

Recommendations and Comments

- Make criminal forfeiture mandatory for any serious offense where proceeds are detected

- Consider simplifying the confiscation regime. As practice develops with the application of forfeiture and pecuniary penalty orders, consider, for example, extending the scope of forfeiture orders to benefits as well. As a result, unless practice reveals that pecuniary penalty orders serve a specific purpose that could not be achieved by forfeiture orders, they could be dispensed with

- Consider introducing a civil (i.e., nonconviction based and noncriminal) forfeiture regime

- Adopt as matter of priority legislation that provides for the freezing of terrorist funds and enables the effective implementation of UN SCRs on FT;

- Ensure, if necessary by issuing regulations, that the CIG regularly circulate UN and other terrorist watch-lists to financial institutions and keeps them abreast of new developments;

- Consider amending the POCA in order to enable the forfeiture of property of organizations that are found to be primarily criminal in nature;

- Make AML/CFT training mandatory for all law enforcement personnel, in particular prosecutors and police officers, who may be involved in the investigation and prosecution of ML and FT offenses; the training should specifically cover the implementation of the POCA and use of its specific powers;

- Ensure that the Crown Law Office is responsible for representing the Cook Islands authorities in all restraining and forfeiture order applications and hearings. It should also be designated as the central body to keep relevant statistics; 
- To make better use of the limited resources, officers who have received AML/CFT training should be designated as AML/CFT trainers and conduct regular AML/CFT training to both the public and private sectors in order to involve them in the AML/CFT process;

- $\quad$ The CIP should include the AML/CFT regime into its basic training program for new recruits. This would serve the purposes of raising awareness on AML/CFT matters amongst law enforcement agents and introducing the new legal concepts for future detectives.

Implications for compliance with FATF Recommendations 7, 38, SR III

FATF 7 - Largely compliant as the necessary legislation exists, but it is untested in practice; in addition, criminal forfeiture is not mandatory

FATF 38 - Compliant

SR III - Noncompliant, as the Cook Islands does not have measures in place to freeze without delay funds or other assets of terrorists, those who finance terrorism and terrorist organizations in accordance with the relevant UN SRC resolutions.

\section{III-The FIU and processes for receiving, analyzing, and disseminating financial information and other intelligence at the domestic and international levels}

\section{(compliance with criteria 17-24)}

Description

\section{FIU mandate}

The Cook Islands FIU is an administrative FIU, which was established by Section 20 of the FTRA 2003 as an independent Ministry. Administrative oversight is vested with the Minister of Finance, who appoints the Head of the FIU. The FIU is the designated competent authority within the Cook Islands for the collection, analysis and dissemination of financial intelligence. It has no investigative mandate. It applied for Egmont Group membership in 2001, which is expected to be granted in June 2004.

Section 27 of the FTRA regulates the FIU's position and functions. The latter are formulated either as positive obligations or as authorizations to carry out functions that include:

- $\quad$ Receiving suspicious transaction reports (STRs); cash transaction reports (CTRs) over threshold \$NZ 10,000 ; electronic funds transfer reports (EFTRs), both inward and outward over threshold \$NZ 10,000; border currency reports (BCRs) over threshold \$NZ 10,000 and intelligence reports;

- Collecting information relevant to serious offenses or ML from public sources;

- Analyzing and assessing all reports and information;

- Referring the case to the Police for investigation if the FIU has reasonable grounds to believe that a serious offense or ML was, is being or may be committed and disseminating financial intelligence and information to other domestic authorities (e.g., Customs) for investigation or action if there are reasonable grounds to suspect ML;

- Compiling statistics;

- Issuing guidelines to financial institutions;

- Providing training to financial institutions on customer identification, record keeping and reporting obligations and identification of suspicious transactions;

- Providing feedback to financial institutions; and

- Undertaking compliance audits for entities not regulated by a supervisory entity.

\section{Obligation to report to the FIU}

Sections 10 and 11 of the FTRA set forth various reporting obligations of financial institutions and provide for sanctions for failure to comply with these obligations.

Section 10 mandates that financial institutions must report to the FIU within 3 working days report: 
- any single cash transaction in excess of \$NZ 10,000 unless the recipient and the sender is a financial institution, as defined by Section 2 of the FTRA 2003;

- any single electronic funds transfer in excess of $\$ N Z 10,000$, whether inward or outward of the Cook Islands.

Financial institutions are punishable by a fine of up to $\$ N Z 10,000$ (individual) or up to $\$ N Z 50,000$ (corporate) for failure to report. Structuring a transaction to avoid reporting (smurfing) is also an offense for the person conducting the transaction and is punishable by a fine of the same amounts.

Section 11 mandates that financial institutions must report to the FIU as soon as practicable but no later than in two working days suspicious transactions, whether completed or attempted. Specifically, the reporting institution must report any information that may:

- be relevant to an investigation or prosecution of a person for serious offense or a ML offense;

- $\quad$ assist in the enforcement of the POCA;

- be related to the commission of a serious offense or a ML offense.

The failure to report suspicious transactions is also an offense, but the sanctions are more severe: for individuals, they range from fines of up to \$NZ 20,000 to two years of imprisonment, and for corporate bodies the fines may go up to $\$ \mathrm{NZ} 100,000$.

\section{Guidelines}

As seen, under Section 27 of the FTRA the FIU has unlimited (and unspecified) authority to issue guidelines to financial institutions, the understanding being that such guidance would be provided on how to comply with the obligations under the FTRA. In practice, the FIU and the FSC plan jointly to issue guidance "as and when required." Guidance notes to financial institutions were first issued pursuant to the Money Laundering Prevention Act 2000, which since then was repealed, and an updated version of these Guidance Notes reflecting the new AML/CFT legislation was under preparation at the time of the mission's visit. The FIU has also circulated to financial institutions, to assist with their in-house training, the Egmont Group 100 cases document and provided a training video and customer pamphlets.

\section{Reporting procedures}

The reporting procedures for suspicious transactions are prescribed by Section 11 (3) of the FTRA. These require that the reports:

- be made in writing;

- contain any details as required;

- contain a statement on the grounds on which the financial institution holds the suspicion;

- be signed or otherwise authenticated by the financial institution.

Standardized forms were printed in October 2003 and were included in the FTR Regulations that the CIG issued on February 18, 2004. The FIU has provided training to all Money Laundering Reporting Officers appointed pursuant to Section 18(2) of the FTRA on how to fill in the prescribed forms in February 2004.

The processing of reports received by the FIU is described in detail by its (Internal) Standard Operating Procedures Manual. 


\section{Obtaining further information}

Section 27 (h) of the FTRA empowers the FIU to ask for further information relating to any suspicious transaction report received by it from a financial institution. Moreover, Section 27 (i) authorizes the FIU to instruct any financial institution to take any steps that may be appropriate in relation to any information or report (STRs or other reports) received by the FIU to enforce compliance with this Act.

Further, Section 30 of the FTRA authorizes the FIU to examine records or look into the business and affairs of any financial institution for the purpose of ensuring compliance, e.g., with the reporting obligations of financial institutions. Financial institutions are required to give all reasonable assistance to the FIU to enable it to carry out its responsibilities and must furnish any information that it may reasonably require. Penalties for failure to cooperate range from a fine up to $\$ N Z 20,000$ to imprisonment of up to two years (individual) and to fines \$NZ 100,000 (corporations).

Law enforcement agencies may also obtain further information under Section 11(5) of the FTRA, which requires that a financial institution that has made a "report" (STRs or other reports) to the FIU must provide, at the request of the law enforcement agency, any further information that it has on the transaction or the parties to the transaction in order to assist an investigation arising from or relating to the information in the original report. The reporting financial institution supplying the additional information has an option to forward it to the FIU or to the requesting law enforcement agency.

\section{Obtaining information from public authorities}

Section 27 (d) of the FTRA authorizes the FIU to request of information from other law enforcement agencies and the supervisory authority, i.e., the FSC. The request must be restricted to "purposes of this Act," that is the FTRA.

\section{Sanctions}

There are sanctions for failure to comply with the reporting obligations under Sections 10 and 11 of the FTRA (see details above). These sanctions are imposed by Courts upon prosecution by the CLO, but the FIU can initiate the process.

\section{Authority to disseminate information for investigation}

The Cook Islands FIU is an administrative unit that receives, analyzes and disseminates financial intelligence. It has no investigative mandate. Section 27 subsection (c) of the FTRA requires that when the FIU has reasonable grounds to believe a serious offense or a money laundering offense has been, is being, or may be committed, the FIU must refer the matter to the Police for investigation.

In addition, Section 27 (f) and (q) of the Act authorizes that the FIU may:

- $\quad$ send any report, any information derived from that report or any other information it receives to the appropriate law enforcement authorities if, having considered the report or information, it also has reasonable grounds to suspect that the transaction is suspicious;

- transmit any information from, or derived from, a compliance audit or supervisory review or suspicious transaction report to the appropriate domestic or foreign law enforcement authority, if it has reasonable grounds to believe that the information is suspicious or is relevant to an investigation for noncompliance with the FTRA, a serious offense or a money laundering offense. 


\section{Information sharing with other FIUs}

Section 29 of the FTRA 2003 regulates disclosure of information by the FIU to foreign agencies. Section 29 (1) specifically authorizes the FIU to disclose its information to an institution or agency of a foreign state or of an international organization established by the governments of foreign states that has powers and duties similar to those of the FIU on the terms and conditions set out in the agreement or arrangement between the FIU and that foreign state or international organization regarding the exchange of information. In this regard, Section 28 of the FTRA allows the FIU to enter into arrangements with "like" bodies in line with the Egmont Group principles. The FIU may, with the approval of Cabinet, enter into negotiations, orally or in writing, relating to an agreement or arrangement, in writing, with an institution or agency of a foreign state or an international organization established by the governments of foreign states that has powers and duties similar to those of the FIU, regarding the exchange of information between the FIU and the institution or agency.

No agreement or arrangement is however necessary for the disclosure of information to a foreign FIU, as Section 29 (2) clearly states that Section 29 (1) does not limit the power of the FIU to disclose its information to an institution or agency of a foreign state or of an international organization established by the governments of foreign states that has powers and duties similar to those of the FIU for the purposes of an investigation, prosecution or proceedings relating to a serious offense or a money laundering offense.

Further, Section 27 (q) authorizes the FIU to transmit any information from, or derived from, a compliance audit or supervisory review to the appropriate domestic or foreign law enforcement authority, if the FIU has reasonable grounds to believe that the information is suspicious or is relevant to an investigation for noncompliance with the FTRA, a serious offense or a money laundering offense.

\section{Data protection and confidentiality}

Section 28 (3) of the FTRA clarifies that the information exchanged with other FIUs must be information that the FIU, institution or agency has reasonable grounds to believe would be relevant to investigating or prosecuting a serious offense or a money laundering offense or an offense that is substantially similar to either offense. In addition, if the FIU supplies information on the basis of an agreement or arrangement, these agreements or arrangements must restrict the use of information to purposes relevant to investigating or prosecuting a serious offense, a money laundering offense or an offense that is substantially similar to either offense; and stipulate that the information must be treated in a confidential manner and must not be further disclosed without the express consent of the FIU.

\section{Statistics}

The FIU keeps statistics on Suspicious Transaction Report, Cash Transaction Report, Electronic Funds Transfer Report, Border Currency Report, and intelligence provided by either domestic or overseas agency. The following data were supplied to the IAE on the number of reports received:

\begin{tabular}{|l|c|c|}
\hline TYPE OF REPORT & & TOTAL-reports rcvd \\
\hline \hline Suspicious Transaction Reports & August 2000-June 2003 & 22 \\
\hline Cash Transaction Report & July 2003-January 2004 & 529 \\
\hline Electronic Funds Transfer Report & July 2003-January 2004 & 2050 \\
\hline Border Currency Report & Since August 2000 & 0 \\
\hline Intelligence & Since October 2001 & 15 \\
\hline
\end{tabular}

All reporting entities, organizations, companies, etc. will be entered onto the purposely-designed FIU database and linked through the unique report number. The FIU indicates that 18 of the STRs received were submitted by banks, 3 by trustee companies and 1 by a CIG agency. 
Full background check on selected reports would be conducted by the Intelligence Officer, who is a fraud investigator loaned from CIP. Since there is yet no report referred to the CIP for further enquiry, no statistics of this nature exist. For similar reasons, the FIU keeps no statistics on either requests made by a foreign agency or cases referred to a foreign agency.

\section{Staff and resources}

The FIU's operation is financed by the Minister of Finance with additional sponsoring by the New Zealand Government. The budget has been raised from \$NZ 100,000 in 2002-03 to \$NZ 256,000 in 2003-04. The increased budget is for the salary of the Head of the FIU and other operational costs. It has authorized professional staff of three, including the head, an Intelligence Officer, and a Compliance Officer.

The head of the FIU is appointed by the Minister of Finance and is responsible for the overall operational performance, financial management, staffing and direction of the FIU. The present head of FIU was previously a member of the New Zealand Police FIU and the FIU Technical Adviser to the Cook Islands for 18 months through the NZAID program. Her contract will expire in June 2004.

The Intelligence Officer is primarily responsible for receiving, evaluating, analyzing, and disseminating intelligence product in relation to reports and information received by the FIU. He is also responsible for conducting local inquiries for relevant overseas agencies and organizations, educating and raising awareness among financial institutions in relation to money laundering typologies and trends, and facilitating training for financial institutions. The Intelligence Officer is a fraud investigator loaned from the CIP to the FIU as an analyst. He has been attached to the NZ Police FIU on three occasions to undergo "on the job" training. He is due to leave the FIU and return to CIP in April 2004.

The FIU has set up its own database, to which it has exclusive, direct access. All transaction reports required by the FTRA and received by the FIU are entered into the database. This occurs whether or not the report is received in electronic or paper form. Information about the entities involved and amount of transaction will be maintained. The database however has no reporting capacity and keeps no record of classification or result of enquiry. It is thus unable to generate any information that is needed for either management or statistical purposes. Since there is an insignificant number of STRs, there is no time limit for the STRs remain on the database.

The FIU has established a practice of conducting a preliminary analysis of STRs. Through the personal contacts of the head of the FIU and the loaned Intelligence Officer, the FIU is able to obtain information from and conduct initial checks with the Customs, Immigration, and CIP. As a general matter, information on criminal convictions can be obtained on a real time basis. If there are reasonable grounds to suspect that the transaction is suspicious, the FIU will send the information directly to the CIP.

If the preliminary analysis does not produce reasonable grounds to suspect the transaction is related to a serious offense, ML or FT, the FIU will conduct further analysis to determine whether the transaction is suspicious, and if no grounds exist, will keep the case active until further information is obtained.

The Compliance Officer, whose position is currently vacant, will be primarily responsible for assessing and enforcing compliance with requirements pursuant to the FTRA. He/she will also be responsible to liaise with Nonregulated Financial Institutions in relation to their compliance, conduct on site examinations, maintain liaison with the FSC to ensure consistency of compliance requirements across both regulated and nonregulated financial institutions, maintain a compliance register, and provide office and management support to the head of FIU.

In terms of technical resources, the FIU has a stand-alone secure computer system that cannot be accessed from outside of the unit. It has a range of office support equipment including desktop PCs phones, faxes, etc., though the adequacy of its premises seems doubtful. 


\section{Analysis of Effectiveness}

The Cook Islands FIU is a new institution, which however has started its effective operation before the FTRA came into force, i.e., in October 2002. The legal framework within which it operates, i.e., the FTRA, the FTRR, and the Standard Operating Procedures Manual, is very comprehensive and reflects the latest international standards and best practice.

A few legal and policy issues are however worth reconsidering under the current arrangements :

- taken as such, the definition of "financial institutions" in Section 2 of the FTRA is overly broad in the context of the FTRA legislation; it is assumed that the intention of the statute was to cover entitieslegal persons and individuals - that need to take the required due diligence measures under the FTRA and, most importantly, to report transactions, suspicious and otherwise, rather than to (re)define "financial institutions" with a potential impact on the entire financial sector and the statutes that regulate it; it is therefore suggested to clarify that the definition covers "reporting" or "obligated" institutions.

- Section 11 (5) offers a choice for "financial institutions" to supply, when so requested by a law enforcement agency conducting an investigation, any additional information that is related to a report it had previously made to the FIU either to the FIU or to the requesting law enforcement agency. However, at the stage of criminal investigation, the requested institution should cooperate with the police or other law enforcement agency conducting the investigation, and provide to the latter, at its request, any additional documentation it may have to help the enquiry. It is unclear to the mission why the FTRA offers this choice and, specifically, why the FIU should receive the information when the reporting entity decides not to supply it to the requesting law enforcement agency. In the interest of expediency, and given the extensive powers that law enforcement agencies were provided with under the POCA to obtain disclosure of documents, it would seem to the mission that Section 11 (5) should be amended to require that the additional information be supplied directly to the law enforcement agency in charge of the investigation.

The FIU statistical figures show the number of reports received by it, but at this stage the FIU keeps no statistics on the number of reports resulting in investigations, prosecutions or convictions, or STRs materially assisting such ventures as no STR was so far forwarded to the CIP.

Besides the issue of premises, the material resources of the FIU seem to be adequate. The FIU office is equipped with IT and office equipments, though these would benefit from upgrading. The budget of the FIU is sufficient for the present structure and workload, but it may not be enough if all statutory FIU functions are to be carried out in combination with its default policy role.

The FIU operates independently and there is no undue influence from outside. There is however a concern with regard to ensuring its adequate staffing, in particular in light of the potential departure of both the head of the FIU and the Intelligence Officer in mid-2004. The unfilled Compliance Officer post also jeopardizes the operation of the FIU.

Both the head of the FIU and the Intelligence Officer are experienced AML law enforcement agents. They are competent in analyzing STRs and operating the FIU. While the current staff of the FIU may be able to cope with the present workload, given the potential for increasing operational and training work, the CIG should plan to reinforce it. For further development of the unit, any new staff to the unit should receive proper training on AML-related matters.

The present intelligence development capacity, such as obtaining background information or conviction records, relies too much on the personal contacts of the head of the FIU and the Intelligence Officer. It will bring a dramatic fall of FIU's intelligence gathering capacity if either one of them leaves the unit. 
Considering the number of banks and financial institutions that operate in or through the Cook Islands, the number of STR is comparatively low. It indicates that the financial sector is not aware of the importance of making STRs or just ignores the reporting requirements. The same situation applies to the Customs and Marine police of the CIP, which are in theory responsible for currency reporting at the broader. It reflects that many professionals and the general public of the Cook Islands as a whole are not sufficiently aware of the newly passed AML-legislation.

The recording of the results of investigations, prosecutions, or convictions into the FIU database is dependent on feedback from investigating and prosecution agencies. This is also the case when information has been provided to a foreign authority. Since the FIU has not yet referred any case for investigation, the practice of getting feedback is not yet established.

Recommendations and Comments

- Amend definition of "financial institutions" to "reporting institutions" in Section 2 of the FTRA 2003;

- Amend Section 11 (5) so that the additional information is supplied to the requesting law enforcement agency directly only;

- In light of the pending expiration of the contracts of the Head of the FIU and the Intelligence Officer, immediate arrangements should be made to ensure that these positions continue to be filled by persons of appropriate qualifications and experience.

- $\quad$ The post of FIU Compliance Officer should be filled as soon as practicable;

- The FIU should establish formal channels of communication, on unit-to-unit basis, for obtaining and sharing information with domestic and overseas agencies;

- $\quad$ The FIU should maintain close liaison with the CIP and pass to the CIP any substantiated intelligence of potential serious crime, ML and FT as required by the FTRA;

- $\quad$ The FIU database should be further enhanced with reporting capacity and include the results and feedback to and from the agency.

Implications for compliance with FATF Recommendations 14, 28, 32

FATF 14 - Largely Compliant, as legal framework exists but compliance monitoring yet to be implemented.

FATF 28 - Largely compliant, as guidelines exist but are not updated

FATF 32 - Compliant

\section{IV-Law enforcement and prosecution authorities, powers and duties}

(compliance with criteria 25-33)

Description

Designated authorities

The overall investigative responsibility lies with the CIP working in conjunction with the Crown Law Office.

\section{Legal basis for investigative techniques}

The Cook Islands legislation does not specifically provide for, nor prohibit investigative techniques such as undercover operations, controlled deliveries, etc. The authorities advised that each of these techniques would be in theory available to investigators, albeit without a legislative basis, but in the context of the Cook Islands, they would not be very practical. None of them was so far used in practice. Nevertheless, an amendment to the CPA adopted in May 2003 created a clear legal basis for the interception of private communications.

Pursuant to Section 96A of the amended CPA, the Police may apply to a Judge of the High Court for a warrant for any member of the Police to intercept a private communication by means of a listening device in any case where there are reasonable grounds for believing that any member of an organized criminal group is planning, participating in, or committing, or has planned, participated in, or committed, criminal offenses of which at least one is an offense of the kind referred to in Section 109A (2) of the CA ["Participating in organized criminal 
group"], as part of a continuing course of criminal conduct planned, organized, or undertaken by members of that group.

The Judge may grant an interception warrant if he/she is satisfied that it would be in the best interests of the administration of justice to do so, and that the following additional conditions are all met:

- $\quad$ there are reasonable grounds for believing that:

(i) there is an organized criminal group; and

(ii) any member of that organized criminal group is planning, participating in, or committing, or has planned, participated in, or committed, criminal offenses of which at least one is an offense of a kind referred to in Section 109A(2) of the Crimes Act 1969 as part of the continuing course of criminal conduct planned, organized, or undertaken by members of that group.

- there are reasonable grounds for believing that evidence relevant to the investigation of the case will be obtained through the use of a listening device to intercept private communications;

- whichever of the following is applicable:

(i) other investigative procedures and techniques have been tried but have failed to facilitate the successful conclusion of the police investigation of the case, or are likely to be too dangerous to adopt in the particular case; or

(ii) other investigative procedures and techniques are unlikely to facilitate the successful conclusion of the police investigation of the case, or are likely to be too dangerous to adopt in the particular case; or

(iii) the case is so urgent that it would be impractical to carry out the police investigation using only investigative procedures and techniques other than the interception of private communications; and

- the private communications to be intercepted are not likely to be privileged in proceedings in a court of law by virtue of Sections 7, 8, or 9 of the Evidence Act 1968 or of any rule of law that confers privilege on communications of a professional character between a barrister or solicitor and a client.

The authorities advised that should the interception of private communications become necessary, they would need to lease the necessary technology from New Zealand.

Under the Police Act, the CIP can authorize, in writing, foreign law enforcement agents to execute constabulary duty within Cook Islands jurisdiction. A similar arrangement can also be made for local police officers to execute the power of a Customs Officer within the restricted area of airport and port.

\section{Use of investigative techniques}

The CIP can use the full panoply of coercive measures and special investigatory powers in all serious crime and ML investigations (and probably the same for FT when the relevant act is passed in the near future). However, in practice these methods have never been used.

\section{Ability to compel financial records}

Under the POCA, Cook Islands law enforcement authorities have various powers to compel production of bank account records, etc., as necessary to conduct investigations of ML and serious offenses. These include production orders, monitoring orders, and search warrants. 
Specifically, Section 85 of the POCA empowers police officers to apply for a warrant to search premises for a "property-tracking" document related to a serious offense. Section 85 (2) clarifies that any document relevant to identifying, locating or quantifying the property subject to the effective control of person convicted or suspected of having committed a serious offense, where there are grounds for believing that he/she derived a benefit from that offense, is to be treated as a property-tracking document.

Further, under Section 79 of the POCA, police officers can apply to a judge for a production order-an order to make a document available for inspection - in respect of any person who may be in possession or control of a property-tracking document. The application may be made ex parte. The production order compels a person to produce to a police officer at a specified time and place any specific property-tracking documents or any documents of that kind in this person's possession or control. Property-tracking documents have the same meaning in this context as defined for search under Section 85.

Further, under Section 87-88 of the POCA, the Solicitor-General can apply to the Court for a monitoring order requiring that a financial institution provide information about transactions conducted during a particular period through an account held by a particular person with the financial institution. The order may be made for a maximum period of six months.

\section{Cooperation and information sharing}

The primary body that promotes interagency cooperation in the ML arena is currently the Combined Law Agency Group (CLAG) under the leadership of the Commissioner of Police. It has representatives from the Customs and Immigration, as well as the FIU.

On the request of the head of FIU, it is planned that the current Anti-corruption Committee would be expanded and changed to be the National [AML] Coordinating Committee (NCC). The committee will consist of the Financial Secretary, the Solicitor-General and the heads of government department that involve in the AML system.

\section{Law Enforcement and prosecution agencies structure, funding, and staffing}

The CIP is a force of 110 police officers under the command of the Commissioner of Police. The Deputy Commissioner of Police is an officer qualified in law and the head of the Criminal Investigation Bureau (CIB) takes up the prime investigative duty within the CIP. The CIB has a strength of 12 detectives and is divided into four sections, respectively responsible for serious crime, drug, fraud, and finger print examination. Because of the small size of the CIB, all officers will be mobilized if there is a major crime investigation to be conducted.

The CIB is equipped with ample staff, computers, printers and has access to a range of vehicles. Internet facilities are available to staff and specialist forensic services are available from the New Zealand Police, the Australian Federal Police, and the Federal Bureau of Investigation. Existing resources seem to be adequate to meet the current operational needs. Having said that, the Commissioner of Police advised that he was seeking additional budget for the whole CIP and, if he were successful, some of these additional resources would be given to the $C I B$.

The Crown Law Office presently has two qualified lawyers: the SG and a senior prosecutor. Currently, two posts of junior prosecutor are vacant. The SG has experienced difficulties in recruiting qualified lawyers to join the office due to the high competitive salaries offered by the private market.

The Customs has 5 full time officers and 20 part time officers. The full time Customs officers will check incoming passengers and goods at both the airport and port. The 20 part time officers are deployed only at the airport for checking arriving passengers. The officers know the threshold for bringing cash in and out of the country. 


\section{Statistics on ML and FT investigations, prosecutions, and convictions}

There is no designated official or agency responsible for keeping such statistics. One of the reasons is that the statistical information is nil.

The CIP has recently established its own intelligence database. All information that comes to the CIP will be inputted into the database. It may help in tracing results of $M L$-related investigations if a case of this sort comes up.

\section{Typologies and trends on current ML and FT methods and techniques}

As there is yet no ML or FT case disclosed to police, it is impossible to identify any typology or trend on ML and FT methods in the Cook Islands. The STRs made to the FIU were not sufficient to draw any conclusion on this regard.

\section{Training in ML and FT}

The Cook Islands have been participants at several AML/CFT training seminars and workshops. Additional training is available from time to time, often sponsored by donor agencies, and as and when the opportunity is provided, some law enforcement staff attend at these presentations. Hence, the three detectives of fraud squad have received ad hoc trainings on $A M L / C F T$.

In March of 2003, because of a joint UN/Commonwealth Secretariat/Pacific Islands Forum Secretariat initiative, an "in country" mentor was in the Cook Islands working with the CIP and representatives of the Crown Law Office. This Technical Assistance program strengthened the capability of the CIP and Crown Law Office in dealing with financial investigations involving Money Laundering, predicate offenses and the Financing of Terrorism, and provided the necessary skills in pursuing action to identify and recover the proceeds of crime. Two officers within the fraud section of CIB were working as "counterparts" with the TA advisor and now have all the necessary skills to undertake the necessary investigations at the conclusion of the program. One of these officers has also attended a five-day instructional course promoted by the Pacific Islands Forum Secretariat, relative to Money Laundering, Proceeds of Crime and financial investigations.

However, the two most experienced fraud investigators are no longer with the CIB, at least for the time being. One of them has joined the staff of the FSC. While the other is on loan to the FIU.

The SG has attended various workshops on AML/CFT and appears to be qualified for prosecuting ML and FT. The Senior Prosecutor is responsible for prosecuting general criminal cases and has not yet been given any training on $A M L / C F T$.

\section{FT, prosecution and forfeiture problems}

To date, there have been no investigations, prosecutions and convictions or seizing of the proceeds of crime in relation to ML. Potential problems from these areas cannot be assessed at this stage.

Having said that, the native freehold land policy, which bars the possibility of forfeiting title over such land (Section 16 of the POCA) in the Cook Islands, may prove to be a potential problem that need to be further considered.

Analysis of Effectiveness

The Cook Islands legal framework of special investigative techniques is not fully in line with the international standards, with the notable exception of interception of private communications, but the size of the community would make their application difficult even if the relevant legislation existed. As the only "special" investigative technique that is at present set forth in legislation is the interception of private communications, which has not yet been applied in practice for lack of required technology, the mission is not in a position to assess their 
effectiveness. However, it notes that conditions of granting an interception order seem very restrictive, e.g., as regards the types of offenses in connection with which an application may be made. Consideration should be given to extending the list of offenses as practice develops and include for example terrorism-related offenses.

The powers available to Cook Islands law enforcement authorities for compelling production of records, through production orders, monitoring orders and search warrants, seem to provide a sufficient basis for carrying out financial investigations without any major impediment. Secrecy obligations are overridden by these powers, even if a general provision such as Sections 35-36 of the FTRA does not exist under the POCA.

The mission notes, however, that at present the law enforcement authorities are not sufficiently familiar with the new powers introduced by the POCA. Training in the new legislation and the use of these powers in financial investigations therefore seems indispensable to help practice evolve.

The CLO and the CIP are designated officials responsible for prosecuting and investigating ML. The SG has received reasonable training on ML matters, but further training should however be provided to other prosecutors in the office as they will be required, at some stage, to handle ML prosecutions in court.

Following the departure of the two most experienced fraud investigators of the CIB, the capacity of CIB in investigating financial fraud and money laundering is seriously affected. Fortunately, both officers are still working in the AML field, and thus it does not jeopardize the overall capacity of the Cook Islands in tackling the ML activities.

It is a practice that CIP will prosecute most of the criminal cases. Being a legally qualified professional, the Deputy Commissioner of Police appears to form his own legal opinion for most of the criminal investigations. Only the potential cases that involve members of the police force will be passed to the CLO. Annually, there are about 15 cases, on average, passed to CLO for legal advice and prosecution. This practice does not seem appropriate for ML cases, which always are accompanied by complex investigations and court procedures.

The ML related laws in Cook Islands are comprehensive. Both the CLO and CIP realize they have the power to compel financial records, but they have yet to attempt to execute this power.

There is a wide range of investigative powers available for the CIB. However, some investigative powers, such as undercover agent operation, are actually not useful in a country with such a small amount of population. Furthermore, the CIB also lacks the resources or technical support to intercept telecommunication, although, under certain criteria, they have the authority to do so. Fortunately, the CIP has backup from other leading agencies, such as the New Zealand police and FBI.

The arrangement for foreign law enforcement agents to execute constabulary duty in the Cooks Island is effective and shows good cooperation amongst the law enforcement agencies. The initiative of CIP and FIU in creating CLAG and NCC is a strategic move on the right path.

It is a perception of both the Crown Law Office and CIP that the FIU would collect and maintain all statistics in respect of STR and for any administrative sanctions imposed on financial institutions. Neither the Crown Law Office nor the Police believe they should keep such statistics. Given the central position of the Crown Law Office in administering the POCA, it would seem to be the best placed public authority to collect ML and FT-related statistical data (investigations, prosecutions and related judicial orders) as practice develops.

In the absence of meaningful ML statistics and actually conduct of an ML case investigation, it is impossible to identify typologies and current trends of ML in the Cook Islands.

Recommendations and Comments

Consider expanding the list of criminal offenses for which the interception of private communications under Section 96A of the amended CPA would be available; 
- With the departure of the two experienced fraud investigators, immediate training should be provided for the only remaining fraud investigator in the CIB. Should resources be available, training should also be given for other detectives in the CIB;

- Similar training should also be given for prosecutors of the Crown Law Office;

- The Crown Law Office should be designated as responsible for collecting and keeping ML-related statistics;

- The FIU, CIP, and Crown Law Office should select amongst the STRs and try to develop a possible ML case, in order to test the capacity of all these units and provide a chance to gain experience for the officers involved.

Implications for compliance with the FATF Recommendation 37

FATF 37 - Compliant

\section{V-International Cooperation}

(compliance with criteria 34-42)

Description

\section{Mutual Legal Assistance}

Mutual legal assistance can be provided by the Cook Islands based on domestic law or international treaties. While domestic law covers both mutual legal assistance (MACMA and POCA) and extradition (EA) matters comprehensively, the Cook Islands at present is not a party to any multilateral treaty in the area of mutual assistance in criminal matters, and it concluded only one bilateral agreement (on the transfer of convicted offenders) in this area.

\section{Assistance under the MACMA}

The scope of MACMA extends to assistance with regard to any "criminal matter," i.e., an offense against a provision of any law of the Cook Islands, for which the penalty is imprisonment for a term of not less than 12 months or a fine of more than $\$ N Z 5,000$, or an offense against a law of a foreign country which had they occurred in the Cook Islands, would have constituted an offense punishable by the same penalties. Mutual assistance from and to the Cook Islands therefore requires dual criminality in general.

The MACMA specifically provides for a range of assistance that can be granted by the Cook Islands in relation to a "criminal matter," though Section 4 does not limit the available assistance to those specifically mentioned. The Act regulates the following types of assistance:

- the taking of evidence and production of documents (Part 3);

- $\quad$ search and seizure (Part 4);

- agreement for persons to give evidence or assist investigations (Part 5);

- custody of persons in transit (Part 6); and

- assistance regarding proceeds of crime (Part 7).

Requests by foreign jurisdictions for Cook Islands assistance in criminal matters must be made in writing to the Attorney-General, the Minister responsible for the Crown Law Office. If the formal requirements set forth by Section 7 MACMA are satisfied, the Attorney-General may authorize the provision of assistance.

Section 11 of MACMA authorizes the Attorney-General to take evidence and transmit evidence to a foreign country that asks for evidence to be taken in the Cook Islands for a proceeding or investigation into a "criminal matter" in the requesting country. Pursuant to Section 11 (2), a requesting country can ask for a document or other article in the Cook Islands to be produced for a proceeding or investigation in the requesting country. If the Attorney-General authorizes the production of a document, a Judge may require that the document be produced to him/her and if it is produced, he/she must send it, or a copy of it certified by the Judge to be a true copy, to the Attorney-General for transmission to the requesting jurisdiction. However, Section 15 (2) provides for an exception to that rule in terms of which compulsion can only be applied by the Judge if the person compelled to 
give evidence, answer questions or produce a document in the Cook Islands would be compellable in the requesting jurisdiction as well.

Unlike the production of documents, which can be granted in relation to any "criminal matter," search and seizure are only available under MACMA for the purpose of a proceeding or investigation involving a serious offense. Section 3 of the MACMA refers back to Section 3 (1) of the POCA for the definition of "serious offense," and it appears that since the amendment of the MACMA by the Mutual Assistance in Criminal Matters Act 2003, enacted on September 10, 2003, the definitions of "criminal matter" under the MACMA 2003 and that of a "serious offense" under the POCA are identical. Search and seizure can therefore be granted by the Cook Islands for any "criminal matter."

With regard to search specifically, Section 18 of the MACMA authorizes the Attorney-General to direct an authorized officer to apply to a Judge for a search warrant if a proceeding or investigation for a criminal matter involving a serious offense has commenced in a foreign country and where a foreign country requests the Attorney-General to arrange for the issue of a warrant; and the Attorney-General believes on reasonable grounds that a thing relevant to the investigation or proceeding is located in the Cook Islands. Once issued by the Judge, under the search warrant, the officer is authorized to enter and search, if necessary with assistance and by any force that is necessary and reasonable, land or premises and subsequently seize the property identified and any other thing that he or she may believe to be relevant to the proceeding or investigation of the requesting country. Once the authorized officer seized the property or other thing, he/she must deposit it into the custody and control of the Commissioner of Police, who may be directed by Attorney-General about its handling and possible delivery to the requesting jurisdiction.

Section 38 of the MACMA provides that upon a foreign country's request, the Attorney-General may make arrangements for the enforcement of a foreign forfeiture order or a foreign pecuniary penalty order. The foreign forfeiture order must be made for a serious offense and against property that is believed to be located in the Cook Islands. The Attorney-General must be satisfied that a person has been convicted of the (underlying) offense and that the conviction and the forfeiture order are not subject to further appeal in the foreign country. This excludes the enforcement of nonconviction based forfeiture or confiscation orders by the Cook Islands. If the AttorneyGeneral is satisfied that the required conditions are met, he/she may apply for the registration of the foreign order by the Court. Upon registration by the Court, such foreign orders are enforced or treated as if they were made by the Court under the POCA.

The MACMA also enables that foreign authorities seek mutual assistance for the purpose of locating and freezing proceeds in the Cook Islands. Section 44 of the MACMA provides that the Attorney-General may, when requested to obtain the issue of a search warrant for property, direct an authorized officer to apply to the Court under the POCA for a search warrant for "tainted property" if a proceeding or investigation for a serious offense has commenced in a foreign country and the Attorney-General believes on reasonable grounds that tainted property of the offense is located in the Cook Islands. In addition, Section 46 of the MACMA also provides that the Attorney-General may direct an authorized officer to apply to the Court under the POCA, for a production order to obtain possession of the property-tracking document; or a search warrant for the property-tracking document under Section 86 of the POCA. Under Section 86 of the POCA, Sections 78 to 85 apply to the order or search warrant, i.e., it is subject to the same enforcement provisions as if it related to domestic proceedings or investigations. The same treatment is given to foreign restraining orders registered under the MACMA - Sections 72 to 77 of the POCA apply to such orders.

Further, the Attorney-General may apply for a restraining order under conditions similar to the search warrant if he/she believes on reasonable grounds that property that may be made or is about to be made the subject of a foreign restraining order is located in the Cook Islands.

Each of the above forms of assistance may also be requested by the Cook Islands from a foreign jurisdiction under similar conditions. 


\section{Assistance under the POCA}

The POCA also regulate search for and seizure of tainted property in the Cook Islands, as well as the execution of restraining orders and production orders, on behalf of foreign jurisdictions, where the underlying serious offense was committed abroad. Given that the definitions of "criminal matter" as defined by the MACMA and that of "serious offense" under the POCA overlap, it is unclear to what extent the execution of any such request is done under the MACMA or the POCA, and whether the two procedures could run parallel.

The procedure for search and seizure pursuant to the POCA (Sections 43-47) is as was described under the MACMA, that is the Attorney-General authorizing, at the request of a foreign jurisdiction, a police officer to seek to obtain a search warrant from a Judge for locating or identifying the tainted property. If the search identifies such property and there are reasonable grounds for believing that it is necessary to seize the property, e.g., for preventing its concealment, loss or destruction, the search warrant is considered as authorizing the seizure of the property as well. Once the property is seized, a forfeiture order must be issued within 30 days, failing which it has to be returned to the person from whose possession it was seized. If the requesting foreign jurisdiction does not request the property's forfeiture, it must at least obtain that a restraining order against the property be issued and registered (recognized) by a Cook Islands Court before the end of the period of 30 days. Sections 72-77 specifically address the procedure applicable in this respect. Section 86 of the POCA also enables foreign jurisdictions to seek the issue of production orders and search warrants on their behalf, in relation to a serious offense committed abroad.

\section{Treaties and UN Resolutions}

As mentioned previously, the UNSCRA allows the CIG to give effect to important Security Council Resolutions, including SCR 1373, by making regulations, though none were so far issued to effectively implement the UN requirements in the area of FT.

The list of applicable bilateral mutual legal assistance treaties only includes a bilateral agreement concluded in 1995 with Western Samoa for the transfer of convicted persons.

As regards extradition, the EA extended the application of the extradition treaties and arrangements that were applicable in the Cook Islands before reaching the current status of sovereignty. Thus, the Cook Islands has extradition arrangements with over 130 countries and territories, including all Commonwealth and Pacific Islands Forum member States.

\section{Use, Implementation, and Tracking of Requests}

Requests for assistance can be broadly divided into two types: informal exchange of information and formal legal assistance.

The CIP has been effective in following up requests for assistance through their own police networks. Records of each request received, and the response provided, are maintained in the Intelligence Office of the CIP.

CLO is responsible to handle request of mutual legal assistance. Given higher priority to domestic matters, the current staffing problem in CLO has affected its ability to give timely and effective follow-up to formal requests for assistance. The CLO to date has received one request.

\section{Extradition}

The EA sets out the procedures for extradition of individuals charged with an "extradition offense," i.e., any offense punishable in both the requesting country and the Cook Islands by imprisonment for not less than 12 months or a fine of more than \$NZ 5,000, which include ML and predicate offenses. The Act also provides for the Cook Islands to extradite its own nationals pursuant to extradition requests from other jurisdictions subject to this dual criminality requirement. It distinguishes between "comity countries," with which the CIG has 
no extradition arrangements in place and "extradition countries," including Commonwealth countries, South Pacific countries and Treaty countries, with which it has. The Act sets forth extradition requirements accordingly. The Act enables the Cook Islands to extradite fugitives to, or receive fugitives from, over 130 "extradition countries" listed in Annex to the Act through simplified procedures (to varying degrees), and regulates extradition to or from any other country.

\section{FT and extradition}

As FT is not yet criminalized, the Cook Islands is currently not in a position to extradite any person sought for FT. This is a major issue for compliance with FATF Special Recommendation V.

\section{Law Enforcement Exchange of Information}

Existing arrangements, principally with Interpol (via New Zealand Police) but also with the South Pacific Islands Criminal Intelligence Network ("SPICIN") provide the mechanisms for the formal exchange of information. These arrangements have no legislative mandate and have evolved over years and years of information exchanging in this manner. Limitations as to the use of the information may be imposed by the providing agency. The Cook Islands law enforcement authorities advised that they always respond to requests for information from external/international agencies. In instances where the identity of the requesting agency is not known, steps are taken to ensure that prior to release, the requesting agency is a reputable and recognized law enforcement body. The MACMA 2003 has not prevented the continuation of the existing exchange of information, but regulated the exchange of information that can be used for evidentiary purposes. Records of each request received, and the response provided, are maintained in the Intelligence Office of the Cook Islands Police.

\section{Cooperative Investigations}

Cooperative investigations are not specifically authorized nor prohibited by any statute. The authorities advised that in addition to the assistance that could be given by the law enforcement authorities under MACMA 2003 and the POCA, the Cook Islands police continue to cooperate with law enforcement agencies in other countries. The mandate for cooperation of this nature is drawn from the authority of the Commissioner of Police. The existing practice is effective and timely, further enhanced by the AML legislation, which permits wider cooperation.

\section{Co-coordinating seizure and forfeiture actions, sharing}

Section 36(2) of MACMA provides that, where the Attorney-General requests a foreign country to make arrangements for the enforcement of a forfeiture order or pecuniary penalty order, the Attorney-General may enter an arrangement with the foreign county to share the amount forfeited or paid.

Section 40(3) of MACMA provides that, where a foreign forfeiture order or pecuniary penalty order is registered in the Court, the Attorney-General may enter an arrangement with a foreign country to share with that country the amount forfeited or paid.

There is yet no request made to a foreign country or a foreign forfeiture order registered in the Court of the Cook Islands.

\section{No terrorist safe-harbor}

FT is not criminalized under the existing legislation.

\section{Financial, human or technical resources}

At present, the number of both outgoing and incoming requests remains low. Both the CLO and CIP manage to meet the demand. In particular, for the police-to-police model, the CIP has been able to deal with requests for 
assistance effectively through its established police network channels or systems. Communication between the CLO and CIP remains minimal; it may affect the cooperation of these two units in handling a formal request of legal assistance.

Analysis of Effectiveness

The legal provisions regulating mutual legal assistance and extradition are comprehensive and are in line with the latest international standards. They are, much like the other parts of the AML-suite enacted in May 2003, largely untested in practice, which makes any meaningful assessment of their effectiveness rather difficult. As practice develops, the authorities will need to review carefully which portions of this legislation work well and correct any deficiency that may arise.

The following are a few issues that may need reconsideration in terms of drafting in the MACMA:

- $\quad$ provision or obtaining assistance under the MACMA is not limited to certain jurisdictions (Section 5), nor is the type of assistance provided or received (Section 4). It is therefore understood that cooperation may be extended to all countries without a process of prior designation. The mission also notes that the MACMA does not specifically require that a treaty, agreement or other arrangement exist for the provision or obtaining of assistance. While this may be proof of the broad authority granted by the Act to provide assistance, the mission considers that for the sake of clarity it might be helpful to explicitly include a provision in Section 4 of the MACMA to the effect that such arrangements are not necessary, subject to obtaining an assurance of reciprocity if necessary;

- the MACMA and the POCA seem to create parallel regimes for the provision of assistance to a foreign jurisdiction with regard to search, seizure, restraining and production orders that are necessary for locating, identifying tainted property related to, or the investigation of, a foreign serious offense; the mission believes that for the sake of clarity, both statutes should provide explicitly, that the execution of a request pursuant to one or the other statute is exclusive and bars ipso facto procedures under the other;

As regards extradition, the absence of criminalization of FT prevents the Cook Islands from extraditing persons sought for FT. This is a major shortcoming, which however the CIG has already identified and is planning to correct with the proposed draft Terrorism Suppression Bill (see under Criteria 1-6).

The Cook Islands has few formal requirements to enable it to cooperate internationally, therefore making it easy for other jurisdictions to cooperate with the Cook Islands.

The CIP has established a good network with foreign law enforcement agencies. The relationship is particularly close with agencies or organizations working within the Pacific region. Requests for information are usually dealt with in an expedient manner.

There was only one formal request made so far to the $C L O$, and thus present financial and human resources are sufficient for dealing with the request. However, in view of the newly introduced the POCA and the coming CFT act, the number of formal request may rise significantly in a short span of time. Additional resources may be needed.

The communication between the CLO and CIP is not effective because information between these two departments is exchanged through informal, personal contacts only. Any change in the personal relationship could disrupt the current exchange mechanism. It is suggested that a more formal communication channel be established at senior levels.

Recommendations and Comments

- $\quad$ Ratify the relevant international treaties in the area of ML and FT, such as the Vienna and Palermo Conventions and the ICSFT and ensure that domestic legislation is in place for their implementation, in particular with regard to the criminalization of FT;

- Consider including a provision in MACMA to expressly permit mutual legal assistance in the absence 
of treaty, agreement or other arrangement, on a discretionary basis, if necessary with an assurance of reciprocity;

- Monitor the practical effectiveness of the MACMA and the POCA statutes in permitting recognition of foreign forfeiture and confiscation orders and consider expanding recognition to nonconviction based (civil) forfeiture orders.

- $\quad$ The Police should be aware of the international cooperation requirements of the AML legislation, for example, pursuant to the POCA, the MACMA and the new EA;

- Coordination between the CIP and CLO needs improvement.

Implications for compliance with FATF Recommendations 3, 32, 33, 34, 37, 38, 40, SR I, SR V

FATF 3 - Largely compliant, as domestic legislation is in place but the Cook Islands has not yet ratified any international treaty related to ML or FT

FATF 32 - Compliant

FATF 33 - Compliant

FATF 34 - Materially noncompliant, as the Cook Islands has not yet ratified any international treaty related to ML or FT

FATF 37 - Compliant

FATF 38 - Compliant

FATF 40 - Compliant

SR I - Noncompliant, as the Cook Islands has not yet ratified the ICSFT nor implemented the relevant UN SCRs SR V - Noncompliant, as the Cook Islands at present is not in a position to afford mutual legal assistance in connection with criminal investigations relating to FT, the latter not being a criminal offense

\section{Assessing preventive measures for financial institutions}

\section{Table 5. Detailed Assessment of the Legal and Institutional Framework for Financial Institutions and its Effective Implementation}

\section{I-General Framework}

(compliance with criteria 43 and 44)

Description

The FTRA is the main instrument that establishes the legal and institutional obligations of financial intermediaries with respect to AML/CFT. It is intended to regulate in a comprehensive manner the application of due diligence measures in financial relationships and transactions in order to combat money laundering.

Specifically, Sections 35 and 36 of the FTRA address confidentiality/secrecy of financial transactions and provide authority that supercedes all other related legislation. These sections compel financial institutions to comply with the reporting and other requirements of the FTRA, and generally provide the basis for providing transaction information to the FIU for AML purposes.

In addition, Section 36 indicates that if there is a conflict between the provisions of FTRA and any other Act including the following Acts, the FTRA prevails:
(a) International Companies Act 1981-82;
(b) International Partnership Act 1984;
(c) International Trusts Act 1984;
(d) Banking Act 2003; and
(e) Off-Shore Insurance Act 1981-82.

The FTRA mandates due diligence, ongoing monitoring of customers and transactions, suspicious activity reporting, development and maintenance of internal procedures for compliance, audit and record keeping. Further, the FTRA establishes the supervision and authority of the FIU, including cooperation with supervisors, and provides for administrative and penal sanctions for noncompliance. 
The FTRA and implementing regulations contain the relevant provisions to enable institutions to develop procedures, systems, and reporting that are compliant with the FATF $40+8$ Recommendations.

According to Section 27 of the FTRA, the FIU is tasked with the responsibility for leading the development of regulatory and procedural mechanisms for covered institutions to follow regarding AML measures. The FIU must receive reports made under Sections 5, 8, 10, 11, and 12 of the FTRA, as well as information from law enforcement agencies within or outside the Cook Islands, and any other information provided about suspicions of a serious offense or money laundering offense.

Sections 27(b)-27(f) provide that the FIU may collect information from available sources, forward or request information from law enforcement or supervisory agency, analyze and assess reports and information, and if it has reasonable grounds to believe a serious offense or money laundering offense has been, is, or may be committed it must refer the matter to Police for investigation.

Sections 27(h)-27(i) provide that the FIU can request further information regarding any suspicious transaction report it receives, and instruct an institution to take any steps that may be appropriate to enforce compliance with the Act.

Sections 27(j)27(o) provide that the FIU may compile statistics and disseminate information and intelligence to domestic and international authorities, issue guidelines to institutions, conduct training in relation to customer identification, record keeping, and identification/reporting of suspicious transactions, and generate information on trends and developments in the identification and detection of money laundering for public awareness and training purposes.

Section 27(p) requires that the FIU conduct compliance audits for all covered financial institutions, except those that are regulated by the FSC. Thus, for licensed financial institutions the FSC is designated under the FTRA to have responsibility and authority for the effective implementation of fully compliant AML regimes.

Section 16(g) of the FSC Act partly defines the function of the FSC to consult with, develop and maintain regular contact with licensed financial institutions with a view to encourage the development of high professional standards within licensed financial institutions, initiating, promoting and maintaining codes of conduct, and developing and maintaining for persons engaged by licensed financial institutions a system of continuing education in respect of issues relating to financial crimes and money laundering.

There are established gateways for communication between the FIU and the FSC on matters that affect both prudential supervision and due diligence; however, these are not yet formalized.

The principal challenge for the FSC and FIU is to develop programs to assess the compliance of institutions that have reporting responsibility under the FTRA. This will require the development of tools to determine where risks are greatest and beyond that to assess the adequacy and effectiveness of systems employed by reporting institutions. Analysis of Effectiveness

The FTRA and implementing regulations, the FSC and Banking Acts provide a reasonable basis for the start of an AML/CFT regime in the Cook Islands. However, the process has only really begun and the operation of the FSC and FIU are at a very nascent stage.

Ensuring the effective implementation of the FATF $40+8$ Recommendations is a shared responsibility between the FIU and the FSC, but no lead agency has been designated by the CIG to drive the implementation process. While a coordination mechanism exists through the NCCT Working Group, in which both the FIU and the FSC participate, policy decisions do not systematically involve the Working Group, nor are all important legislative amendments discussed there. The absence of clear consultation procedures and decision-making responsibilities in this regard may jeopardize the integrity of the AML regime.

Secrecy provisions in banking, trust and company legislation were overridden by Section 36 of the FTRA, though 
consequential amendments have not been made in the statutes concerned.

Recommendations and Comments

- For the sake of clarity, the statutes referred to at Section 36 of the FTRA should be amended accordingly to reflect the superior interest of AML enforcement over secrecy provisions

- A lead agency should be designated to coordinate and ensure the implementation of the overall AML regime

- Any policy decision in the area of AML should involve the inter-agency consultation and decision-making process

- The policy process would be strengthened by the re-casting of the Working Group as a policy-making body to lead both the FIU and FSC in terms of approach to development of the AML/CFT regime.

Basic compliance examination procedures should be developed as a pilot exercise, perhaps with a combination of FIU and FSC staff, and rolled out with a sample set institutions to gauge compliance with all of the relevant requirements of the FTRA and determine the need for future action and/or guidance.

The authorities should finalize and issue detailed AML/CFT guidance Notes for all reporting institutions. Implications for compliance with FATF Recommendation 2

FATF 2 - Largely compliant - While the legal and regulatory structures are largely in place, yet the implementation capacity is not capable of effective oversight, compliance monitoring, and enforcement.

\section{II-Customer identification}

(compliance with criteria 45-48 for the (i) banking sector; (ii) insurance sector; (iii) securities sector; and (iv) other financial institutions sector, plus sector specific criteria 68-83 for the banking sector, criteria 101-104 for the insurance sector and criterion 111 for the securities sector)

Description

Anonymous accounts are not legally permissible in the Cook Islands; Section 7 of the FTRA imposes affirmative obligations to establish identity and beneficial ownership of all contracting parties, including the directors or controlling persons of legal entities. Section 7 of the FTRA requires that financial institutions maintain accounts in the true name of the account holder and prohibits a financial institution from opening, operating or maintaining an account in a fictitious or false name.

Part 4 of the CID Regulation requires that financial institutions must verify the customer identification information through the provision of a valid photographic government-issued identification such as a passport or driver's license, as well as a second form of identification, which can be nonphotographic and include bank references, employment references, utility bills, or copy of an election register. This does not apply if the customer remits funds by bank check or letter of credit issued by a regulated financial institution, or from an account in the name of the customer held with a regulated financial institution; the customer is a central or local government or agency; is an association listed on an approved exchange; is an existing customer who has already provided official identification; or the customer is an existing customer and the transaction involves less than \$NZ 10,000.

The FTRA Section 4.3(c) requires financial intermediaries to identify customers when entering into business relationships and to repeat the identification if there are any doubts about the identity of the contracting person (or individual representing a legal entity that is a contracting party) or about the beneficial owner during the course of the business relationship.

Part 3 of the CID Regulation specifies that the information that must be maintained on customers include:

- For individuals, the full name, date and place of birth, nationality, address, and occupation.

- For associations, (which includes any association of persons, any company, corporation, firm, partnership, joint venture, mutual fund, statutory body, association, organization, state or agency of a state but not a trust) the name of the association, place and date of incorporation, address of registered office and principal place of business; the full name, occupation, date and place of birth, and permanent residential address of 
each significant interest holder and officer.

However, Part 6 of the CID regulation indicates that Section 4(1) of the FTRA does NOT apply where a customer is a regulated financial institution, acting either in its own right or on behalf of another institution; or to any transaction where the recipient and the sender are regulated financial institutions. The CID Regulation defines, for purposes of the regulation, a regulated financial institution is a financial institution in the Cook Islands, or a person resident, based, carrying on business, or incorporated in or formed under the laws of an approved jurisdiction carrying on business in relation to which a foreign regulatory authority exercises regulatory functions and includes a wholly owned subsidiary thereof.

Part 6 does not identify specific high-risk jurisdictions whose AML/CFT frameworks are not capable of ensuring compliance of its regulated institutions with the FATF recommendations. Further, the CID Regulation conflicts with the requirements of the FTRA regarding customer identification by providing an exception, which does not exist in the law.

The minimum requirements for customer due diligence are set forth in significant detail in the FTRA and the newly promulgated implementing regulations. Compliance is mandatory and violations are subject to sanctions, both administrative and criminal.

The implementation of customer due diligence requirements will be enforced by compliance audits of banks, insurance, securities, trustees, and other financial institutions covered by the legislation. In the case of licensed financial institutions (banks, trusts, insurance companies), it appears clear that these will be conducted primarily by the FSC. At the time of the assessment, the FSC had conducted one inspection of a bank as part of a broader examination, and utilized a questionnaire borrowed from another jurisdiction.

The compliance audit of other nonlicensed covered entities will be done directly by the FIU, which is not yet capable of performing audits directly. It may be an option to have these functions performed by third party contractors such as auditors or other consultants.

There is no explicit prohibition of numbered accounts, nor is there any exemption from customer identification requirements for numbered accounts.

Section 4(1) of the FTRA requires that all financial institutions establish and verify the identity of the contracting party through official documentation as soon as practicable and before any person becomes a customer. For legal entities, this includes the name, legal form, address, director's names, principal owners and beneficiaries, and proof of authorization to conduct business in the entity's name. It further must obtain information on the purpose and conduct ongoing due diligence on its customer. Furthermore, Section 4(4) of the act requires establishment of the ultimate beneficial owner or the person for whom the transaction is being conducted.

Part 3 of the CID Regulations which prescribes the minimum customer information for trusts includes the name of the trust, address of any registered office, service address; an explanation of the nature of the trust and description of purpose and beneficiaries; full name, occupation, date and place of birth, and permanent address of each settlor or trustee.

The FTRA Section 4.2(a)(iii) requires that financial institutions must verify the provisions regulating the power to bind the entity; and to verify that any person purporting to act on behalf of the customer is authorized to do so, and identify those persons.

Financial intermediaries, including money remitters, are required to include specifically originator information on funds transfers and other forms of transfers, including related messages, under Section 9 of the FTRA. Standardized reporting forms for financial institutions for electronic transfers are included in the newly promulgated FTR Regulations. 
Institutions visited appeared to adhere to the requirements of the FTRA in relation to identification of their customers. There are some instances in which full adherence to these requirements is not practicable. It is not uncommon, for example, for some persons to be known by an alias which will not be supported by any official identification document. In such cases financial institutions rely on verification by members of staff who know that customer.

Notably, in March 2003, the Commissioner for Offshore Financial Services apparently circulated draft Guidance Notes on the Prevention and Detection of Money Laundering and Terrorist Financing in the Cook Islands ("the Draft Guidance Notes"). These notes provide significantly better guidance and detail than those that were promulgated in 2001, and contain detailed guidance related to customer due diligence for individuals, businesses, trust and fiduciary customers, as well as other matters related to the compliance with the FATF principles. However, while circulated for comment, they were never officially promulgated.

Given that there are some institutions that have fairly well-developed AML/CFT compliance regimes, it would benefit the FSC and the FIU to conduct an initial risk assessment of regulated and nonregulated entities to allocate resources away from those institutions that would pose less risk.

There is currently no effective mechanism for authorities to check on the due diligence performed on the approximately 800 international companies (ICs) that were registered at the time of the mission. The responsibility to undertake due diligence for these entities lies with the six trustee companies. However, the FSC does not undertake compliance checks of trustee companies and under its current initiative to strengthen its supervisory infrastructure, it will not develop this capacity. In addition, the Registrar of Companies does not have information on the beneficial owners of the ICs it registers, nor on the real activities of these companies.

Furthermore, several legal provisions currently in force in the area of trust law may have an undesirable effect for the implementation of the FTRA's due diligence requirements. For example, the provision contained in Section 26 of the International Trusts Act 1984, Section 224 of the ICA, Section 77 of the International Partnerships Act 1984 and Section 23A of the Off-shore Insurance Act 1981-82, allowing the Minister of Finance and Economic Management to exempt any international trust, international company, international partnership or holder of an offshore insurance license from having to comply with any of the provisions of their respective Acts, has the potential to defeat the FTRA's objectives. Specifically, while the ICA requires the identification of the holders of bearer shares, the Minister may exempt any international company from complying with this requirement. The mission shares the view that the Ministerial exemption should either be abolished or truncated so it can only be granted in limited specific cases where only minor issues of administrative compliance are involved.

Another issue is that at present a potential litigant against an international trust is statute barred from even finding out the fact that trust exists in the Cook Islands. This seems to result from the excessive confidentiality provisions for trusts. The mission shares the view that the requirement in place before the passage of the International Trusts Amendment Act 1995-96 that trustee companies display a list of the trusts they provide a registered office for should be restored, with perhaps the practical modification that such list not have to be displayed but must be available for the public to inspect during normal working hours.

Analysis of Effectiveness

While the implementing Regulations issued under the FTRA usefully supplement the statutory AML provisions in general, in the area of offering companies and customer identification, the exemptions granted by the FTRR clearly contradict the FTRA's relevant provisions. This conflict of law is rather unfortunate and may defeat the purpose of enacting primary legislation. The mission believes that the traditional principle of hierarchy of legal norms should not be challenged, unless at the expense of upholding the rule of law in the Cook Islands. Further, the definitions in the various regulations on "licensed" or "regulated" financial institutions appear to overlap and contradict each other as well as statutory provisions governing the same matter. These contradictions may lead to confusion as to what a financial institution is actually supposed to do or not to do.

If the intention of the exemptions created by the implementing regulations is to create a regime for introduced 
business this should be done by explicitly providing for such a regime in accordance with international best standards.

Discussions with banks and trust companies indicated that some institutions already have rigorous customer identification procedures in place. In some cases the local office utilizes the group-defined procedures of their respective organizations, which often have had more stringent regulatory regimes in other jurisdictions. This is largely the case for the Australian-based bank branches, and a number of the trust companies as well. A number indicated that the Cook Islands operations were encompassed by global consolidated supervision and audit by the home office/group leadership, and that training in AML/CFT was also provided.

The weakness identified in the due diligence arrangements for ICs does not pose a direct risk to the CI as most ICs do not conduct business within the $\mathrm{CI}$ and $\mathrm{CI}$ financial institutions are obliged to undertake due diligence on all customers, including ICs. On the basis of anticipated applications for banking licenses, there will be a maximum of 11 banks in the foreseeable future, and the FSC is working to develop the capacity to undertake both on-site and ofsite supervision of these institutions. However, in the non-banking sector as a significant number of companies will remain unsupervised and as these ICs are conducting business internationally, the real threat is to the international financial community. Countries with AML/CFT regimes that do not meet international standards could find their financial institutions establishing relationships with Cook Islands ICs for which proper due diligence was not undertaken.

In addition, several aspects of trust law referred to above may hamper the implementation of the FTRA's due diligence requirements and would need to be carefully reviewed to ensure that they are consistent with the FTRA.

Recommendations and Comments

- $\quad$ The FSC should develop a compliance program that encompasses all regulated financial institutions as soon as possible, as at present the state of the development of compliance regimes, internal controls, and other aspects/elements of an AML/CFT program at other than one domestic bank is unknown.

- Furthermore, Part 6 exempts CID requirements for transactions from any foreign regulated institution, which diminishes the value of maintaining an AML/CFT framework. This conflict between the FTRR and the statutory provisions of the FTRA should be resolved as a matter of priority by eliminating any provision in the Regulations that diminishes the scope of the identification requirements set forth by the FTRA.

- Guidance should be issued that directs reporting institutions to take special care when conducting transactions with institutions residing in countries with weak AML/CFT compliance regimes.

- The notion of "approved jurisdictions" seems overly broad and does not guarantee that introducers maintain international best practice, and should therefore be avoided.

- The draft 2003 Guidance notes should be adapted to reflect recently enacted laws and regulations, and then formally promulgated.

- $\quad$ The FSC needs to develop an effective mechanism to undertake meaningful supervisory surveillance of trustee companies and the Registrar of Companies should ensure that the beneficial owners of ICs are identified, verified and this information is kept updated.

- It is critical that protocols be established to ensure that best international practices for "introduced business" are followed throughout the business relationship.

- The CID regulation should be amended to require that any financial institution that accepts business from a third party must:

a) satisfy itself that the third party is regulated and supervised

for, and has measures in place to comply with the provision of Section 4 of the FTRA;

b) should immediately obtain the necessary information required under Section 4 of the FTRA and

c) should take adequate steps to satisfy themselves that copies of identification data and other relevant documentation required under Part 2 of CID will be made available from the third party upon request without delay.

Implementing a framework for introduced business as outlined above will require a level of supervisory 
sophistication that is beyond the current capacity of the FSC. The adoption of a regime should therefore be deferred until such time that the requisite supervisory capacity is developed by the FSC or is available through other means.

- Certain aspects of trust law need to be carefully reviewed to ensure that they are consistent with the FTRA's due diligence requirements.

Implications for compliance with FATF Recommendations 10, 11, SR VII

FATF 10 - Materially Noncompliant-While the requirements of the law would be consistent with FATF 10 , the newly promulgated regulations directly contradict the rigid customer identification requirement. This conflict should be eliminated throughout the regulatory framework. The weakness in respect of compliance checks of trustee companies must be rectified.

FATF 11 - Materially Noncompliant-The newly promulgated regulations directly contradict the rigid customer identification requirement. This conflict should be eliminated throughout the regulatory framework.

SR VII - NA

\section{III-Ongoing monitoring of accounts and transactions}

(compliance with Criteria 49-51 for the (i) banking sector; (ii) insurance sector; (iii) securities sector; and (iv) other financial institutions sector, plus sector specific criteria 84-87 for the banking sector, and criterion 104 for the insurance sector)

Description

Section 8 of the FTRA requires financial institutions to pay special attention to all complex, unusual, large and patterns of transactions, as well as those that do not contain complete originator information. It further requires that transactions that originate or involve persons or businesses in jurisdictions that do not have adequate systems in place to prevent or deter money laundering receive enhanced scrutiny. Section 8(2)a makes it incumbent upon the institution to examine the background, purpose and nature of the transaction and make a written record of its findings. Section 8(2)b requires financial institutions to report these findings to the FIU or law enforcement agency, and to assist in any investigation related to a serious offense or money laundering offense.

Section 6(2) of the FTRA requires banks to be able to re-construct transactions for the FIU or other law enforcement agencies to aid in the investigation of possible offenses. However, in discussions with banks it was reported that automated reporting systems designed to identify multiple related transactions for identifying movement of funds in amounts that would otherwise require reporting to the FIU were not in place at two of the three domestic banks. Still, given the small size of the sector, if the number of transactions is fairly low, it is possible that manual identification of suspicious structuring of transactions could be effective.

Section 4(3)c of the FTRA requires financial institutions to conduct ongoing scrutiny of any transactions undertaken throughout the course of a customer relationship to ensure transactions are consistent with the institution's knowledge of the customer, the customer's business and risk profile, and where necessary the source of funds.

Section 8 of the FTRA provides the legal requirement to scrutinize transactions with persons in jurisdictions that do not have adequate systems in place to prevent or deter AML/CFT.

Discussions with the banking institutions indicated that in some instances

there is a lack of clarity in terms of what the NCCT List represents, its purpose, and usefulness in AML/CFT programs.

Section $8(1)$ (c) of the FTRA specifically requires institutions to give enhanced scrutiny to wire transfers that do not contain complete originator information.

Guidance Notes issued by the MLPA in 2001. Section 54 and Appendix C provide additional but brief guidance on what is considered a "Suspicious Transaction," and the FIU provided training in February 2004 to reporting institutions on the completion of relevant forms as well as case study materials in ML typologies. It also provided 
information on jurisdictions that had weak systems for the detection and prevention of money laundering.

Discussions with banking institutions as well as a review of documented procedures indicated that staff of financial institutions we noted that in at least one instance where personnel could use additional training in recognizing unusual patterns of client activity. Still, most of the documented procedures adopted by the institutions visited reportedly list NCCT jurisdictions and other countries over which there is some level of concern about AML/CFT standards. In general, it is reported that a higher level of due diligence is required when dealing with business associated with these countries.

Analysis of Effectiveness

The legal framework for the ongoing monitoring of accounts and transactions is generally adequate, and the FIU has taken the initiative to conduct fairly comprehensive training on the requirements of the FTRA, reporting forms, and the role of the FIU. The overall framework would be strengthened if new, more relevant and complete Guidance Notes broadened the focus of its guidance in respect of business relationships and transactions with persons from countries with inadequate AML/CFT systems. There are also concerns with respect to enhanced scrutiny to wire transfers and reporting of unusual or complex transactions from these countries.

Recommendations and Comments

- $\quad$ The FIU and/or the FSC should issue the draft guidance notes that address enhanced scrutiny for countries with inadequate AML/CFT systems.

- Further training in patterns and practices of suspicious activities would be beneficial.

- In addition to the initial efforts made by the FIU, the FSC and the FIU should also develop permanent systems to warn reporting institutions of countries which do not have adequate AML/CFT systems and to provide other relevant information such as lists published by the Counter Terrorism Committee of the UN Security Council. The system should include a mechanism to update previous notices as new information becomes available.

Implications for compliance with FATF Recommendations 14, 21, 28, SR VIII

FATF 14 - Largely Compliant-Legal framework is developed but yet to be implemented.

FATF 21 - Largely Compliant. While there is a requirement for enhanced scrutiny related to transactions with persons in jurisdictions that do not have adequate systems in place to prevent or deter AML/CFT, the FSC is not yet able to assess compliance.

FATF 28 - Largely compliant. Further guidance on identification of suspicious transactions and industry-specific typologies are necessary.

\section{IV-Record keeping}

(compliance with Criteria 52-54 for the (i) banking sector; (ii) insurance sector; (iii) securities sector; and (iv) other financial institutions sector, plus sector specific criterion 88 for the banking sector, criteria 106 and 107 for the insurance sector, and criterion 112 for the securities sector)

Description

Customer record keeping is addressed in Section 6 of the FTRA.

(1) A financial institution must establish and maintain:

(a) records of all transactions carried out by it and correspondence relating to the transactions;

(b) records of a person's identification and verification obtained in accordance with Section 4;

(c) records of all reports made to the FIU; and

(d) records of all enquiries made to or by the financial institution by the FIU.

(2) Records required under subsection (1) are those records that are reasonably necessary to enable the transaction to be readily reconstructed at any time by the FIU or by a law enforcement agency.

(3) Records referred to in subsection (2) must contain particulars sufficient to identify the name, address and occupation (or, where appropriate, business or principal activity) of each person:

(a) conducting the transaction; and

(b) if applicable, on whose behalf the transaction is being conducted.

(4) In addition, the documents used by the financial institution to identity and verify each person must have sufficient 
particulars to identify:

(a) the nature and date of the transaction;

(b) the type and amount of any currency involved;

(c) the type and identifying number of any account with the financial institution involved in the transaction;

(d) if the transaction involves a negotiable instrument other than currency, the name of the drawer of the instrument, the name of the institution on which it was drawn, the name of the payee (if any), the amount and date of the instrument, the number (if any) of the instrument and details of any endorsements appearing on the instrument; and

(e) the name and address of the financial institution, and of the officer, employee or agent of the financial institution who prepared the record.

(5) The records mentioned in subsection (1)(a) must be kept:

(a) for a minimum period of 6 years from the date of any transaction or correspondence; and

(b) in the Cook Islands or, if kept elsewhere, in a manner and form that allows the FIU to reproduce, within three working days, that record in usable form in the Cook Islands

(6) The records mentioned in subsections (1)(b), (c) and (d) must be kept:

(a) for a minimum period of 6 years from the date the account is closed or the business relationship ceases, whichever is the later; and

(b) in the Cook Islands or, if kept elsewhere, in a manner and form that allows the FIU to reproduce, within 3 working days, that record in usable form in the Cook Islands.

(7) If a financial institution contravenes subsections (1) to (4), the financial institution commits an offense punishable by:

(a) in the case of an individual, to a fine of up to $\$ \mathrm{NZ} 5,000$; and

(b) in the case of a body corporate, to a fine of up to $\$ N Z 20,000$.

(8) A copy of any record required to be kept under this Act may be kept:

(a) in a machine-readable form, if a paper copy can be readily produced from it; or

(b) in an electronic form, if a paper copy can be readily produced from it and an electronic signature of the person who keeps the record is retained.

The FTRA provides sufficient guidance for the needs of banking institutions. No industry-specific guidance or requirements have been issued by the FSC or the FIU to address particular needs of the insurance sector.

Discussions with regulated financial institutions indicated that actual record-keeping practices comply with the minimum statutory requirements. Institutions indicated that their own requirements varied from 7 to 20 years for different types of information.

Analysis of Effectiveness

The guidance for record keeping contained in the FTRA is quite extensive, but lacks clarity in some areas. For example since section 6 (2) provides further details of requirements for transaction records, the reference contained in this section should be to subsection (1) (a) and not subsection (1). Also since section 6 (4) is also providing further requirements about transaction records, it would be useful if this were not a separate subsection but a continuation of section 6 (3).

Actual practices in the institutions appear to be at least as stringent as the FTRA requirements, and in some cases surpass the minima.

As of yet, apart from the one bank examination, there has not been any checking of the compliance systems, so the overall effectiveness of implementation has not been documented. The banks with which meetings were held appear to be operate in compliance with record keeping requirements of the FTRA.

Recommendations and Comments

- The wording of section 6(2) of the FTRA should be amended to read as follows:

"Records required under section (1) (a) are those records that are reasonably necessary to enable the transaction to be readily reconstructed at any time by the FIU or by a law enforcement agency."

- The following wording should replace the current section 6(4) of the FTRA, should not be a separate 
subsection and should follow immediately after section 6 (3) (b):

"As well as the documents used by the financial institution to identify and verify the identity of each such person."

- The FSC should undertake an initial process to determine whether banks have adequate record-keeping systems and procedures to provide assurance that compliance will be maintained.

Implications for compliance with FATF Recommendation 12

FATF 12 - Largely compliant - The FSC and FIU need to conduct more extensive compliance checking to ensure there is at least a suitable minimum level of compliance among covered institutions.

\section{V-Suspicious transactions reporting}

(compliance with Criteria 55-57 for the (i) banking sector; (ii) insurance sector; (iii) securities sector; and (iv) other financial institutions sector, plus sector specific criteria 101-104 for the insurance sector)

Description

Section 11 of the FTRA specifically requires financial institutions to report within two days if it has reasonable grounds to suspect that information it has concerning any transaction that has been completed or attempted if it may be relevant to an investigation or prosecution for a serious offense or money laundering offense, may be of assistance in the enforcement of the Proceeds of Crime Act or is in any way related to the commission of a serious offense or money laundering offense. The current reporting system does not apply to FT.

Section 11(2) provides penalties, including fines and/or imprisonment, for failure to comply with the reporting requirement. In urgent matters, original reports may be made orally, with written report required within three days (Section 11(4)).

Section 18(2) requires that institutions must appoint a Money Laundering Reporting Officer responsible for ensuring compliance with reporting requirements under the act by establishing and maintaining procedures and systems to implement reporting requirements; make officers and employees aware of laws related to money laundering; make officers and employees aware of procedures, policies, and audit systems adopted by it to deter money laundering; provide training to officers and employees in recognition of suspicious transactions; and establish an audit function to test its anti-money laundering procedures and systems. However, since the enactment of the FTRA there have been no STRs filed, which suggests a lack of understanding among the industry as to what constitutes suspicious activity.

The FIU has provided training in February 2004 on the reporting requirements under the FTRA, and has circulated via electronic mail guidance on the detection of patterns of suspicious financial activity by their customers in the form of 2001 and 2002 FIU typologies and 100 sanitized cases that illustrate money laundering activities and techniques prepared by the Egmont Group.

Section 11(5) provides that a financial institution that has made a report must provide the FIU or law enforcement agency carrying out an investigation of the report any further information it has about the transaction or attempted transaction. Failure to comply with Section 11(5) is punishable by fines and/or imprisonment (Section 11(6)). Section 12 makes similar reporting requirements for suspicious transaction incumbent upon any supervisory authority or auditor.

Section 16 of the FTRA provides protection from civil, criminal, or disciplinary proceedings against a financial institution, supervisory authority, or auditor, or officer/agent thereof that makes in good faith any report of large, complex or suspicious transactions or activity pursuant to the requirements of the FTRA, except in the case of "tipping off" customers in relation to reporting suspicious activity.

Section 14 of the FTRA prohibits any financial institution, its officers, employees or agents from warning (or "tipping off") any person or entity that a suspicious activity report has or may be made, or that a financial institution has formed a suspicion, or any other information that if disclosed would be reasonably expected to inform that a suspicion has been formed and/or that a suspicious activity report may be made. Contravention of the requirements 
of Section 14 is punishable by fines and/or imprisonment. Moreover, Section 27 (i) of the FTRA empowers the FIU to instruct a financial institution to take any steps that may be appropriate in relation to any information or report it has received and the FIU has additional powers to enforce compliance with such instructions under Section 31, which include obtaining a judicial injunction against the non-compliant institution and fines. Moreover, Section 11 (5) provides that at the request of a law enforcement agency, a financial institution that has made a report must provide further information to the requesting agency or to the FIU.

Discussions with financial institutions revealed some uncertainty with regard to the what might constitute tipping off a customer.

While the FTRA applies to all forms of financial institutions, including the insurance sector, no specific industry guidance has been put forth.

Analysis of Effectiveness

The systems in place at this time are generally adequate for ML, but they do not cover FT. However, to date there have been no STRs forwarded to the FIU since the June 2003 enactment of the standard forms. This would suggest either there is a lack of understanding of suspicion, or that there is some other issue causing financial institutions to withhold potential reports.

The current tipping-off provisions of the FTRA seem adequate and provide the necessary protections.

Any potential amendment of the tipping-off provisions seeking to exempt disclosure of information between financial institutions about an STR being made to the FIU would be contrary to the very purpose of the FTRA. Recommendations and Comments

- The suspicious transaction reporting system should be extended to FT.

- The FIU and FSC should open up further dialog with financial institutions to determine the level of understanding of suspicious activity concepts to identify potential gaps or bottlenecks in the process. Initiatives toward this end should also focus on clarifying what constitutes the tipping off of a customer.

- The draft 2003 Guidance Notes should be updated against the new legislation and issued as soon as possible.

- The FIU should continue its training efforts to reinforce the actions that have already taken place, particularly by providing training in the recognition of suspicious transactions.

Implications for compliance with FATF Recommendations 15, 16, 17, 28, SR IV

FATF 15 - Largely Compliant. Further guidance on identification of suspicious transactions and industry-specific typologies would enhance the reporting process.

FATF 16 - Compliant.

FATF 17 - Largely Compliant. There has been a lack of demonstrated understanding of these requirements among banks and other institutions with respect to the tipping off offense.

FATF 18 - Largely Compliant. The relationship between institutions and the FIU needs to be further developed to ensure the system of ongoing training and guidance is effective.

FATF 28 - Largely Compliant, as the Guidance Notes were not updated at the time of the mission.

SR IV - Noncompliant as the reporting system does not address FT.

\section{VI-Internal controls, Compliance and Audit}

(compliance with Criteria 58-61 for the (i) banking sector; (ii) insurance sector; (iii) securities sector; and (iv) other financial institutions sector, plus sector specific criteria 89-92 for the banking sector, criteria 109 and 110 for the insurance sector, and criterion 113 for the securities sector)

\section{Description}

58. Section 18 of the FTRA states that a Compliance Officer appointed under Section 17 of the Financial Supervisory Commission Act 2003 is responsible for compliance with Sections 4, 6, and 7 of the FTRA implementing customer identification, record keeping and retention requirements.

58.1 Further, a financial institution must appoint a Money Laundering Reporting Officer at the management level to ensure compliance with all reporting requirement prescribed by Sections 10 and 11 of the FTRA by establishing and 
maintaining procedures systems to implement reporting requirements, train its officers and employees and agents to recognize suspicious transactions, make officers and employees aware of the laws relating to money laundering, and audit systems adopted by it to deter money laundering.

Discussions with the regulated institutions indicated that training practices vary among institutions. Some conduct regular staff meetings in which the requirements of internal AML/CFT policies and procedures, as well as regulatory developments and requirements are discussed. While other institutions have more formalized, targeted training for employees that deal with customers and/or must be knowledgeable of AML/CFT issues. One institution reported that regular semi-annual training was conducted and that assessments were conducted afterwards to gauge the level of understanding gained from the training exercise.

59. Section 17 of the Financial Supervisory Commission Act 2003 requires all licensed financial institutions, including banks, trustee companies, offshore insurance companies, and persons carrying out insurance business in the Cook Islands an to appoint a Compliance Officer at management level to establish and maintain policies, procedures, and accounting mechanisms to enable the financial institution to meet its obligations under any enactment applicable to it in respect of customer identification, record keeping and retention, and any other matters that may be prescribed by regulation. A newly adopted Qualification of Compliance Officers Regulation 2004 provides that Compliance Officers must have at least three years work experience in finance, law, accounting, or insurance either within or outside the Cook Islands.

60. Section 8 (licensing) (b) of the Banking Act 2003 requires that directors and managers of licensed financial institutions be a "fit and proper person" and have sufficient experience in banking to be involved with operations of a bank, and Section $8(\mathrm{c})$ requires that each associate of the applicant bank also be "fit and proper person" to have an interest in the bank. Associates include persons with significant interest in the applicant, as well as holding companies and subsidiaries of the applicant.

There are no other laws or regulations regarding screening procedures to ensure high standards of employees are present.

61. Section 17 of the FSC Act of 2003 and Section 18 of the FTRA generally imply that foreign branches and subsidiaries are included in the requirements to meet AML standards of the Cook Islands in that these laws make no distinction between foreign and domestic operations.

The banks that currently operate in the domestic market do not have foreign branches and subsidiaries. This situation may change depending on the decisions made on the current applications for new international banking licenses.

61.1 No provisions exist to address situations where minimum AML/CFT requirements differ between home and host jurisdictions. The two branches of foreign banks each reportedly comply with the requirements of their home jurisdiction (Australia).

Analysis of Effectiveness

The general framework for internal controls, compliance, and audit are in place in the FTRA and the FSCA, and there is a regulation on Compliance Officer Qualifications that provides a brief experience requirement. However, neither the FTRA nor the FSC Act explicitly require that institutions apply AML/CFT requirements to branches and majority owned subsidiaries located abroad.

Recommendations and Comments

- $\quad$ The FIU/FSC should consider providing more descriptive guidance on audit system components for AML/CFT compliance systems, as well as more detailed guidance on the skills requirements for Compliance Officers appointed by financial institutions.

- $\quad$ There should be legal/regulatory guidance provided to promote sound practices when vetting employees who may assume higher-risk positions within institutions.

It would likely be useful to provide more descriptive guidance on the role of Compliance Officers and Money Laundering Reporting Officers, and what are acceptable combinations and divisions of duties in practice. 
- As part of a risk assessment exercise, the FSC should seek to determine and document the training practices of institutions to help identify those that pose lower risk. This would further aid in allocating resources to higher risk institutions.

- The FSC should indicate that financial institutions are expected to apply AML/CFT requirements to branches and majority owned subsidiaries located abroad. This should be reinforced through the Guidance Notes and the FSC 's surveillance activities.

Implications for compliance with the FATF Recommendations 19, 20

FATF 19 - Largely Compliant—While there is a legal requirement, there has been no implementation or compliance testing.

FATF 20 - Largely Compliant-There is no explicit requirement or guidance stipulating that legal and regulatory obligations should be applied to foreign branches and subsidiaries.

\section{VII-Integrity standards}

(compliance with Criteria 62 and 63 for the (i) banking sector; (ii) insurance sector; (iii) securities sector; and (iv) other financial institutions sector, plus sector specific criterion114 for the securities sector)

\section{Description}

62. Section 15 of the FSC Act 2003 confirms the duty of the FSC to keep under review Cook Islands legislation relating to licensed financial institutions, and to continually monitor the extent to which the Cook Islands legislation and supervision complies with "internationally accepted standards." Section $16(\mathrm{~g})$ partly defines the function of the FSC to consult with, develop and maintain regular contact with licensed financial institutions with a view to encourage the development of high professional standards within licensed financial institutions, initiating, promoting and maintaining codes of conduct, and developing and maintaining for persons engaged by licensed financial institutions a system of continuing education in respect of issues relating to financial crimes and money laundering.

The general requirement above applies to all regulated financial institutions. However, except for banking institutions there are no well-established standards of conduct, integrity, and preclusion of those with prior criminal history from sensitive positions.

62.1 Section 8(1)a of the Banking Act 2003 addresses the qualifications and integrity of directors, managers, and associates of applicant banks with the concept of "fit and proper person," and who possesses sufficient experience in banking to be involved with the operations and/or management of a bank. However, it does not specifically preclude those with criminal records from holding significant investments or positions with banks.

Prudential Regulation No. 1-2004 on bank licensing also indicates that a due diligence will be conducted to ensure that key persons, managers, directors, and significant shareholders are "fit and proper" to hold positions in banking institutions. Section 2(4) of the Banking Act 2003 defines a disqualified person in part as:

(a) one who has been convicted of an offense under the Act

(b) one that is or has been a director or is or has been directly or indirectly concerned in the management of a licensee or a bank or other financial institution within or outside the Cook Islands which had its license revoked or was wound up by a court

(c) one that has been convicted by a court in any jurisdiction of and offense involving dishonesty

Section 27(2) of the Banking Act 2003 prohibits the appointment of a "disqualified person" as an officer of its banking business, and Section 27(4) prohibits a disqualified person from accepting an appointment or continuing in an appointment as an officer of a banking business. Contravention of these requirements can be punishable by fines for the institution, and fines and/or prison in the case of a natural person.

Section 5B of the Trustee Companies Act 1981-1982 and Section 5 of the Offshore Insurance Act 1981-1982 provide the FSC with the authority to request information, presumably including criminal history, of applicants and related persons. No other guidance related to the integrity or competence of financial institutions other than banks has been promulgated. 
No specific guidance with respect to lower-level employees in key risk positions relative to AML/CFT, persons with criminal history, and required procedures for vetting employees of banking or other institutions are included.

62.2 Section 8(1)a of the Banking Act 2003 addresses the qualifications and integrity of directors, managers, and associates of applicant banks with the concept of "fit and proper person," and possessing sufficient experience in banking to be involved with the operations and/or management of a bank.

63. Offshore activity in the Cook Islands is dominated by International Companies and International Trusts. These vehicles are incorporated and managed by Trustee companies which are captured under the FTRA and are therefore required to undertake full customer due diligence on these vehicles and their principals. International companies themselves are not subject to direct reporting requirements under the FTRA unless they are licensed as a bank, an offshore insurance company or are otherwise captured under section 2 of the Act. To the extent that charities and non-profit organizations are registered as international companies they are subject to due diligence undertaken by trustee companies.

Charities and non-profits generally register under the Incorporated Societies Act 1994. This registration gives them basic tax benefits and the ability to function as legal entities. A register of these entities is maintained by the registrar of the court. The Revenue Management Department also maintains a list of charities. Charities must be "gazetted" by Revenue Management to be eligible for tax benefits. The department does not maintain a list of non-profit organizations. The Cook Islands Non-Government Organization maintains a list of non-profit organizations.

Apart from the reporting requirements under the FTRA and the registration and administrative arrangements as outlined above, there appear to be no laws, regulations or regulatory arrangements that specifically address integrity issues related to charities, non-profit organizations and shell companies in the context of ML and FT.

Analysis of Effectiveness

The establishment of the FSC is an extremely important first step in the effort to improve the prudential regulation and AML/CFT oversight regime in the Cook Islands. However, as yet there have been few operational steps to implement comprehensive compliance and enforcement activities. This is certainly due to the newness of the institution, and it is recognized that such measures will take time to develop and implement. At this time, other than domestic banking, the rest of the financial sector is either under lax regulatory regime or under no government supervision. For certain financial institutions under government licensing, such as trust companies and insurers, the licensing requirement does not specifically refer to a fit-and-proper test. While the Integrity Standards set out under the Banking Act 2003 are generally sound and rigorous, the acts governing the other regulated institutions have not been similarly updated to reflect the modern concerns and practices relative to these standards. Other financial institutions as defined by the FTRA are not regulated by the FSC and are not required to obtain a license. Recommendations and Comments

- It would be useful for the laws governing nonbank regulated financial institutions to be updated and rationalized to provide a similar standard as those applied to banks with respect to prudential matters,

- The FIU/FSC should issue guidelines that address the need for the performance of background checks for persons in sensitive positions relative to potential money laundering activities.

- The current regulatory framework should be strengthened to better address the regulation of charities and non-profits and shell companies.

- The government should introduce statutory fit-and-proper tests for directors, managers, and significant shareholders at the time of licensing/change in ownership of all regulated financial institutions. In addition, the fit-and-proper test should be made an ongoing requirement.

Implications for compliance with FATF Recommendation 29

29 - Non-Compliant. Legal and regulatory measures do not set "fit and proper" standards regarding control and participation of financial institutions other than banks. 


\section{VIII-Enforcement powers and sanctions}

(compliance with Criteria 64 for the (i) banking sector; (ii) insurance sector; (iii) securities sector; and (iv) other financial institutions sector, plus sector specific criteria 93-96 for the banking sector and criteria 115117 for the securities sector)

\section{Description}

64. Under Section 18(2)f of the FSC Act 2003, the FSC has the power to direct a licensed financial institution that has failed to comply in whole or part with any obligation under the Act or any license issued under the Act to implement any action plan to ensure compliance with those obligations. Under Section 18(3), the failure to comply is an offense punishable by fines and/or imprisonment. This appears sufficiently broad so as to compel licensed financial institutions, including those in the banking, insurance sectors to comply with regulations and guidelines issued by the FSC.

Section 17 of the Banking Act 2003 indicates the FSC may take enforcement action against a licensee (bank) if it has contravened the Banking Act or Regulations, conducts business in a manner detrimental to the public interest or those of depositors or creditors, is likely to become insolvent, has failed or is likely to fail, is not compliant with a Directive of the FSC within the time specified, is in breach of any term or condition of its license, or has furnished the FSC with any false/inaccurate, or misleading information. Further, it can take enforcement action if the licensee (bank), or an officer or shareholder is convicted of any offense involving dishonesty by any court within or outside the Cook Islands, or, in the opinion of the FSC, a person with an interest in a licensee (bank) or is an officer is found not to be "fit and proper," or has refused or failed to cooperate with a compliance examination conducted by the FSC. According to Section 17(2), the enforcement can take the form of license revocation or suspension (under Section 11 of the Banking Act), appointment of an examiner to carry out an investigation (under Section 18 of the Act), or appointment of a manager (under Section 21 of the Act).

Under Section 19 of the Banking Act, the FSC is empowered to issue a Directive to compel the institution to Cease and Desist a practice, contravention, or noncompliance, or take such action (including action to replace or strengthen management) as may be specified in the directive to correct the conditions resulting from the practice, contravention, or noncompliance.

Pursuant to Section 17 of the Financial Supervisory Commission Act 2003, financial institutions are required to appoint a Compliance Officer responsible for establishing and maintaining office and accounting procedures to meet obligations in respect of customer identification, recordkeeping and retention and any other matters prescribed by regulation. The FSC has the power pursuant to Section 18 of the FSC Act to enter premises of a regulated financial institution to carry out review of compliance with the FSC Act and may carry out a compliance inspection of a bank in accordance with Section 15 of the Banking Act 2003. Pursuant to Section 18(2)(b) of the FSC Act, they may require a financial institution or any officer or employee to supply such information or explanation as the FSC may reasonably require.

There are also sanctions for failure to comply with the reporting obligations under Sections 10 and 11 of the FTRA for all financial institutions defined as such in the Act. These sanctions are imposed by Courts.

Analysis of Effectiveness

The legal framework provides ample enforcement authority for the FSC to take enforcement action against institutions that do not have or maintain adequate compliance systems. However, until a meaningful compliance checking system is put in place at least in the traditional financial sector, these enforcement powers will remain virtual.

Recommendations and Comments

- The FSC should seek to implement a compliance program for regulated institutions.

- The authorizing legislation for nonbank financial institutions should be revised to reflect a similar approach and level of enforcement authority as provided in the banking law for banking institutions. 


\section{IX-Cooperation between supervisors and other competent authorities}

(compliance with Criteria 65-67 for the (i) banking sector; (ii) insurance sector; (iii) securities sector; and (iv) other financial institutions sector, plus sector specific criteria 97-100 for the banking sector and criteria 118120 for the securities sector)

Description

65. The FTRA and FSC Act designate the FSC and the FIU as the primary actors in the Cook Islands for developing, overseeing, and enforcing AML/CFT compliance among covered institutions, while the Police are tasked with investigation and prosecution of suspected offenses.

The FSC is tasked with the prudential oversight of all regulated financial institutions, including checking compliance with AML/CFT legislative and regulatory requirements. At present, this includes one domestic commercial bank, two branches of foreign banks, and several offshore banks, trust companies, offshore insurance entities, and insurance providers. The exact number of the nonbanking institutions presently operating in the Cook Islands, licensed or not, is not presently known. Furthermore, it is uncertain just how many institutions will apply for a new license under the recently enacted FSC and Banking Acts.

The supervisory staff of the FSC includes one Commissioner, one Senior Examiner, and two Examiners.

At present, the only staff member of the FSC with supervisory experience and background is the Commissioner, who has been with the organization since September 2003. The other three supervision staff member are brand new to regulation and have begun training in supervisory techniques, theory, and processes. At this stage, there is very little capability for the FSC to fully carry out its responsibilities for both prudential supervision as well as AML/CFT compliance. Nonetheless, as part of their training in on-site examination of the domestic commercial bank, the examiners performed some due diligence regarding the bank's AML policies, programs, and processes. The examination included the provision of an interim questionnaire that was completed by the institution and evaluated by the examination team. Findings are being evaluated, and any relevant concerns are to be addressed by the FSC. At this point examination policies and procedures with respect to AML/CFT have not been drafted, though there are plans to obtain outside resources to aid in this regard. However, at this point details have not been finalized.

The FIU is charged with similar responsibility for checking compliance with nonregulated financial institutions that are covered by the FTRA. This includes a broad array of businesses, organizations, and possibly individuals that would have reporting requirements under the FTRA, the exact number of which is unknown but believed to be more than one thousand. Now, the FIU has focused primarily on developing the legal/regulatory framework that enables reporting by financial institutions, and setting up its own operations. The staff of the FIU presently includes one Head of the Unit, and one Intelligence Officer, while the position of Compliance Officer is yet unfilled. Given the relatively large number of covered institutions, it will be some time before the FIU is capable of carrying out its mandate to check compliance in any significant manner.

66. Section 22(2) of the FSC Act provides that the FSC may disclose information to other competent domestic authorities for investigations and prosecutions, as well as other specified matters within an appropriate confidentiality regime. However, there is no specific provision directed at domestic authorities regarding cooperation beyond simple disclosure, including the lending of expertise to investigations.

Section 47 of the Banking Act prevents disclosure of protected information (whether or not a person has an account, name of account, balance and history, amount or details of any individual transaction) except those authorized by a Court, as part of performing the duties under the Banking Act or any other Act, suspicious transaction reporting under the FTRA, required under a warrant, with the express or implied consent of the licensee or person concerned or if available to the public from another source.

67. Section 23(1) of the FSC Act provides that the FSC may disclose to an overseas regulatory authority information, including civil or administrative investigations and proceedings to enforce laws, regulations, and rules administered by that authority. The FSC may decline to disclose information unless it has satisfied itself that the intended recipient 
authority is subject to adequate legal restrictions on further disclosures; the FSC has been given an undertaking by the recipient authority to not, without the consent of the commission, disclose the information provided; the FSC is satisfied that the assistance requested is required for the purposes of the overseas regulatory authority's lawful regulatory function; and that the FSC is satisfied that information provided pursuant to the exercise of its powers under subsection (3) will not be used in criminal or other proceedings against the FSC or any other person providing the information.

Section 20(3) of the FSC Act provides that the FSC may require any licensed financial institution, or any director, other officer or employee of such licensed financial institution, to supply to the FSC in such form and within such time as the FSC may determine, such information as the FSC considers necessary to enable it to carry out its functions, pursuant to section 20 of the Act. The FSC may also obtain compulsory powers.

Where, in accordance with Section 23, the FSC is satisfied that assistance should be provided in response to a request by an overseas regulatory authority, it may in writing direct any person reasonably believed to have information relevant to enquiries to which the request relates, within a stated time, to:

(a) provide the FSC with specified information or information of a specified description with respect to any matter relevant to the inquiry to which the request relates;

(b) produce specified documents or documents of a specified description relevant to that inquiry; or

(c) give to the FSC such assistance in connection with that inquiry as the FSC may specify in writing.

\section{Analysis of Effectiveness}

The framework for cooperation with supervisory authorities is generally adequate. The FSC does not however appear to have an adequate level of trained resources to cover AML/CFT as well as all other areas of risk. Likewise, the FIU is not presently equipped to carry out its mandated compliance audits of nonregulated financial institutions as defined under the FTRA. Some concern exists relative to the legislative authorization of higher levels of cooperation by the FSC with other domestic authorities in the conduct of investigations.

\section{Recommendations and Comments}

- The level of resources in the FSC's Supervisory Division should be assessed once the rationalization of licensing has been completed to ensure it has adequate human and other resources to carry out its supervisory and compliance role.

- The FIU's Compliance Officer Position should be filled to ensure that all areas of risk related to the operation of licensed institutions are adequately covered.

- The basis and extent of cooperation of the FSC with other domestic authorities should be expanded in the FSC Act.

- As part of the FSC's overall development it would be helpful to set forth a strategic plan specifically addressing AML/CFT issues to be included among the other supervisory initiatives it must undertake. This would include performing a risk assessment of regulated institutions to aid in the allocation/prioritization of examination resources, as well as key steps needed to develop appropriate supervisory guidance and procedures. This exercise could be conducted in cooperation with the FIU to enable the sharing of information, techniques, and resources.

Implications for compliance with FATF Recommendation 26

FATF 26 - Materially noncompliant. While a FIU has been established and is operating, its capabilities are not consistent with its responsibilities. Presently there is one unfilled position, making the FIU incapable of carrying out even basic compliance functions, and the FIU's critical information sharing role is largely untested. 


\title{
Description of the controls and monitoring of cash and cross-border transactions
}

\author{
Table 6. Description of the Controls and Monitoring of Cash and Cross-Border Transactions
}

\section{FATF Recommendation 22:}

\section{Description}

Under Section 96 of the PCA, any person who leaves or arrives in the Cook Islands with more than \$NZ 10,000 in cash or negotiable bearer instruments shall report the fact to the Customs. In practice, all arriving passengers must complete an Arrival Declaration. At the back of the Arrival Card, passengers are required to complete a Baggage Declaration, which is a list of items that needed to be declared. Cash of over \$NZ 10,000 or the equivalent is one of the items on the list. There is, however, no declaration mechanism for departing passengers.

The Customs will enquire with the passenger making the declaration. If the Customs officer is satisfied that the money is not related to any serious offense, the Customs will complete a Border Currency Report and pass it to the Financial Intelligence Unit. Baggage of arriving passengers is randomly checked by the Customs. So far, the Customs have not found any large cash transportation at checkpoints of airport and the seaport or received any declaration of cash over the threshold. It is unclear, however, to what extent the obligation of declaration is effectively enforced, in particular at the seaport. Hence, the Customs made so far no Border Currency Report to the Financial Intelligence Unit.

The Marine Police of the Cook Islands Police is responsible for patrolling the border but, similar to the Customs, they so far not made any Border Currency Report to the Financial Intelligence Unit.

FATF Recommendation 23:

Description

Section 10 of the FTRA requires that financial institutions report to the FIU any transaction of an amount in cash exceeding \$NZ 10,000, or any other amount that may be prescribed, in the course of a single transaction, unless the recipient and the sender is a financial institution. These Cash transaction reports ("CTRs") are made available to the FIU on standardized forms and then processed by the FIU staff. Around 500 CTRs were submitted to the FIU at the time of the assessment visit.

Interpretative Note to FATF Recommendation 22:

Description

See above. There is no requirement currently in place to notify the Customs or other authority of overseas jurisdictions from which the shipment originated or is destined to, if undeclared cash is detected at the border.

\section{Ratings of Compliance with FATF Recommendations, Summary of Effectiveness of AML/CFT efforts, Recommended Action Plan and Authorities' Response to the Assessment}

Table 7. Ratings of Compliance with FATF Recommendations Requiring Specific Action

\begin{tabular}{|l|l|l|}
\hline FATF Recommendation & $\begin{array}{l}\text { Based on Criteria } \\
\text { Rating }\end{array}$ & Rating \\
\hline $\begin{array}{l}1-\text { Ratification and implementation of the Vienna } \\
\text { Convention }\end{array}$ & 1 & Noncompliant \\
\hline $\begin{array}{l}\text { 2- Secrecy laws consistent with the } 40 \\
\text { Recommendations }\end{array}$ & 43 & Largely compliant \\
\hline
\end{tabular}




\begin{tabular}{|c|c|c|}
\hline $\begin{array}{l}3 \text { - Multilateral cooperation and mutual legal assistance } \\
\text { in combating ML }\end{array}$ & $34,36,38,40$ & Largely compliant \\
\hline $\begin{array}{l}\text { 4-ML a criminal offense (Vienna Convention) based on } \\
\text { drug ML and other serious offenses. }\end{array}$ & 2 & Compliant \\
\hline $\begin{array}{l}5-\text { Knowing ML activity a criminal offense (Vienna } \\
\text { Convention) }\end{array}$ & 4 & Compliant \\
\hline $\begin{array}{l}7 \text { - Legal and administrative conditions for provisional } \\
\text { measures, such as freezing, } \\
\text { seizing, and confiscation (Vienna Convention) }\end{array}$ & $7,7.3,8,9,10,11$ & Largely compliant \\
\hline $\begin{array}{l}8 \text { - FATF Recommendations } 10 \text { to } 29 \text { applied to nonbank } \\
\text { financial institutions; (e.g., foreign exchange houses) }\end{array}$ & & See answers to 10 to 29 \\
\hline $\begin{array}{l}10-\text { Prohibition of anonymous accounts and } \\
\text { implementation of customer identification policies }\end{array}$ & $45,46,46.1$ & Materially Noncompliant \\
\hline $\begin{array}{l}11-\text { Obligation to take reasonable measures to obtain } \\
\text { information about customer identity }\end{array}$ & $46.1,47$ & Materially Noncompliant \\
\hline $\begin{array}{l}12 \text { - Comprehensive record keeping for five years of } \\
\text { transactions, accounts, correspondence, and customer } \\
\text { identification documents }\end{array}$ & $52,53,54$ & Largely compliant \\
\hline $\begin{array}{l}14 \text { - Detection and analysis of unusual large or otherwise } \\
\text { suspicious transactions }\end{array}$ & $17.2,49$ & Largely compliant \\
\hline $\begin{array}{l}15 \text {-If financial institutions suspect that funds stem from } \\
\text { a criminal activity, they should be required to report } \\
\text { promptly their suspicions to the FIU }\end{array}$ & 55 & Largely compliant \\
\hline $\begin{array}{l}16 \text { - Legal protection for financial institutions, their } \\
\text { directors and staff if they report their suspicions in good } \\
\text { faith to the FIU }\end{array}$ & 56 & Compliant \\
\hline $\begin{array}{l}17 \text { - Directors, officers and employees, should not warn } \\
\text { customers when information relating to them is reported } \\
\text { to the FIU }\end{array}$ & 57 & Largely compliant \\
\hline $\begin{array}{l}18-\text { Compliance with instructions for suspicious } \\
\text { transactions reporting }\end{array}$ & 57 & Largely compliant \\
\hline $\begin{array}{l}19 \text { - Internal policies, procedures, controls, audit, and } \\
\text { training programs }\end{array}$ & $58,58.1,59,60$ & Largely compliant \\
\hline $\begin{array}{l}20-\text { AML rules and procedures applied to branches and } \\
\text { subsidiaries located abroad }\end{array}$ & 61 & Largely Compliant \\
\hline $\begin{array}{l}21 \text { - Special attention given to transactions with higher } \\
\text { risk countries }\end{array}$ & $50,50.1$ & Largely Compliant \\
\hline $\begin{array}{l}26 \text { - Adequate AML programs in supervised banks, } \\
\text { financial institutions or intermediaries; authority to } \\
\text { cooperate with judicial and law enforcement }\end{array}$ & 66 & Materially noncompliant \\
\hline 28 - Guidelines for suspicious transactions' detection & $17.2,50.1,55.2$ & Largely compliant \\
\hline $\begin{array}{l}29 \text { - Preventing control of, or significant participation in } \\
\text { financial institutions by criminals }\end{array}$ & 62 & Noncompliant \\
\hline $\begin{array}{l}32 \text { - International exchange of information relating to } \\
\text { suspicious transactions, and to persons or corporations } \\
\text { involved }\end{array}$ & $22,22.1,34$ & Compliant \\
\hline $\begin{array}{l}33 \text { - Bilateral or multilateral agreement on information } \\
\text { exchange when legal standards are different should not } \\
\text { affect willingness to provide mutual assistance }\end{array}$ & $34.2,35.1$ & Compliant \\
\hline $\begin{array}{l}34 \text { - Bilateral and multilateral agreements and } \\
\text { arrangements for widest possible range of mutual } \\
\text { assistance }\end{array}$ & $34,34.1,36,37$ & Materially noncompliant \\
\hline 37 - Existence of procedures for mutual assistance in & $27,34,34.1,35.2$ & Compliant \\
\hline
\end{tabular}




\begin{tabular}{|l|l|l|}
\hline $\begin{array}{l}\text { criminal matters for production of records, search of } \\
\text { persons and premises, seizure and obtaining of evidence } \\
\text { for ML investigations and prosecution }\end{array}$ & & \\
\hline $\begin{array}{l}38 \text { - Authority to take expeditious actions in response to } \\
\text { foreign countries' requests to identify, freeze, seize and } \\
\text { confiscate proceeds or other property }\end{array}$ & $\begin{array}{l}11,15,16,34,34.1, \\
35.2,39\end{array}$ & Compliant \\
\hline 40 - ML an extraditable offense & 34,40 & \\
\hline $\begin{array}{l}\text { SR I - Take steps to ratify and implement relevant United } \\
\text { Nations instruments }\end{array}$ & 1,34 & Compliant \\
\hline SR II - Criminalize the FT and terrorist organizations & $2.3,3,3.1$ & Noncompliant \\
\hline SR III - Freeze and confiscate terrorist assets & $7,7.3,8,13$ & Noncompliant \\
\hline $\begin{array}{l}\text { SR IV - Report suspicious transactions linked to } \\
\text { terrorism }\end{array}$ & 55 & Noncompliant \\
\hline $\begin{array}{l}\text { SR V - provide assistance to other countries' FT } \\
\text { investigations }\end{array}$ & $34,34.1,37,40,41$ & Noncompliant \\
\hline $\begin{array}{l}\text { SR VI - impose AML requirements on alternative } \\
\text { remittance systems }\end{array}$ & $45,46,46.1,47,49,50$, & N/A \\
& $50.1,52,53,54,55,56$, & \\
\hline $\begin{array}{l}\text { SR VII - Strengthen customer identification measures for } \\
\text { wire transfers }\end{array}$ & $62,58,58.1,59,60,61$, & \\
\hline
\end{tabular}

Table 8. Summary of Effectiveness of AML/CFT Efforts

\begin{tabular}{|l|l|}
\hline Heading & \multicolumn{1}{|c|}{ Assessment of Effectiveness } \\
\hline $\begin{array}{l}\text { Criminal Justice Measures and International } \\
\text { Cooperation }\end{array}$ & \\
\hline I-Criminalization of ML and FT & $\begin{array}{l}\text { The Cook Islands has not yet ratified any international } \\
\text { treaty on ML or FT, though it has put it place much of } \\
\text { the required implementing legislation for the Palermo } \\
\text { Convention (for example, it criminalized various bribery } \\
\text { offenses and participation in organized criminal groups). } \\
\text { The similar requirements of the Vienna Convention } \\
\text { regarding the ML-offense and confiscation are also } \\
\text { largely met by the current legislation (POCA), while the } \\
\text { Narcotics Act 1965 would benefit from a consequential } \\
\text { revision to satisfy the Convention's other requirements. } \\
\text { Notwithstanding the existence of implementing } \\
\text { legislation, the mission regards the lack of ratification of } \\
\text { international treaties as a significant shortcoming, e.g., } \\
\text { because it prevents the Cook Islands from participating } \\
\text { in international cooperation set up under these treaties. } \\
\text { In addition, the CIG has not implemented the UN SCRs } \\
\text { on FT either, in particular SCR 1373, as it has not issued } \\
\text { the necessary regulations under the United Nations } \\
\text { (Security Council Resolutions) Act 2003. As FT has not } \\
\text { been criminalized yet, this is also considered by the } \\
\text { mission as a major issue for compliance with the } \\
\text { international standards. }\end{array}$ \\
\hline
\end{tabular}


As no ML charge was laid by the prosecution authorities in the Cook Islands up to date, it is difficult to assess the practical effectiveness of the current ML provision. The Cook Islands criminalized ML for the first time in 2000 by the Money Laundering Prevention Act 2000, which was later repealed, but no prosecution was brought under this earlier statute either. The repealed and current ML provisions are broadly similar. The disappointing prosecution results do not seem to be linked to the definition of the ML, which is in line with the latest international standards, but rather to an obvious lack of focus on proceeds in criminal investigations combined with a lack of familiarity with the ML offense. The only serious deficiency of the current ML provision is that the scope of "serious offense" does not extend to FT and related terrorism offenses as these are not yet criminalized. The authorities are aware of this deficiency and are working towards an early enactment of the necessary legislation.

In addition, there are several areas, where the mission believes that the legal regime of the ML offense could be made more robust and these amendments could help the process of implementation. The mission suggests in particular to:

- criminalize expressly the laundering of one's own proceeds in Section 280A;

- include "willful blindness" among the knowledge standards;

- include additional penalties for legal entities or professionals engaged in ML or FT, such as withdrawal of license or bar from exercising a professional activity;

- $\quad$ enable that the penalties foreseen for the ML offense under Section 280A may be combined.

The FT is not yet listed as a serious offense in the Cook Islands legislation and is thus not covered by the current AML legal regime. It is however reasonable to presume that FT will be incorporated into the current $A M L$ system. In respect of AML legislation, the Cook Islands drew inspiration from the model provisions of international organizations, such as the IMF and from the domestic laws of various countries, principally of New Zealand. Hence, the AML legal regime of Cook Islands is comprehensive. It provides law enforcement agencies with sufficient powers to investigate and prosecute ML offenses. However, both the investigation and prosecution agencies are unfamiliar the new AML legislation and still put their main focus on the arrest and prosecution of principal offenders but pay little attention to the possibility of restraining and forfeiting 


\begin{tabular}{|c|c|}
\hline & $\begin{array}{l}\text { the proceeds of crime. } \\
\text { High Court Judges of Cook Islands are stand-in from } \\
\text { New Zealand Judiciary and are not based on the } \\
\text { Islands. Each judge will stay on the Island and hear } \\
\text { cases for two weeks by turn. Although it is not yet tested, } \\
\text { the Solicitor-General advised that phone conferences } \\
\text { with judges residing in New Zealand could be arranged } \\
\text { by the Cook Islands Court Registrar if the CLO needed } \\
\text { to apply urgently for a court order under the POCA. The } \\
\text { signed order would be faxed from New Zealand to the } \\
\text { Cook Islands. This arrangement is sensible and meets } \\
\text { the need where urgent action is required. } \\
\text { Justices of Peace (JPs), who sit at the low-level courts } \\
\text { of the Cook Islands and juries at the High Court, are } \\
\text { laymen. It is anticipated that they would have certain } \\
\text { difficulties to understand the ML related laws. In respect } \\
\text { of the High Court judges of the Cook Islands, they are } \\
\text { legally qualified judges of New Zealand and thus their } \\
\text { competency to try the ML cases is not in doubt. As there } \\
\text { is yet no prosecution of ML case tried in courts of the } \\
\text { Cook Islands, it would be inappropriate to guess any } \\
\text { potential difficulties in prosecuting ML offense and } \\
\text { make comment on the sentence for convicted defendants. }\end{array}$ \\
\hline $\begin{array}{l}\text { II-Confiscation of proceeds of crime or property used to } \\
\text { finance terrorism }\end{array}$ & $\begin{array}{l}\text { As a result of the enactment of the POCA, the legal } \\
\text { provisions regulating the confiscation regime (criminal } \\
\text { forfeiture and pecuniary penalty orders) and provisional } \\
\text { measures are comprehensive and broadly conform to the } \\
\text { international standards. However as no property was } \\
\text { ever restrained, seized or forfeited under the current } \\
\text { legislation, the working of this regime has yet to be } \\
\text { tested in practice. This obviously makes it difficult for } \\
\text { the mission to assess its actual effectiveness. However, } \\
\text { the fact that the current confiscation regime is } \\
\text { discretionary may explain, at least partly, why it is not } \\
\text { implemented in practice. In addition, the reasons for the } \\
\text { current distinction made in the POCA between two } \\
\text { different classes of legal action, forfeiture orders on the } \\
\text { one hand and pecuniary penalty orders on the other, are } \\
\text { unclear, in particular in light of the broad definition of } \\
\text { tainted property. The mission considers that given the } \\
\text { significant potential for overlap, unless there are } \\
\text { compelling policy reasons, it is worth considering } \\
\text { whether they should be maintained separately. One } \\
\text { possibility would be to extend the notion of tainted } \\
\text { property to "benefits." }\end{array}$ \\
\hline
\end{tabular}




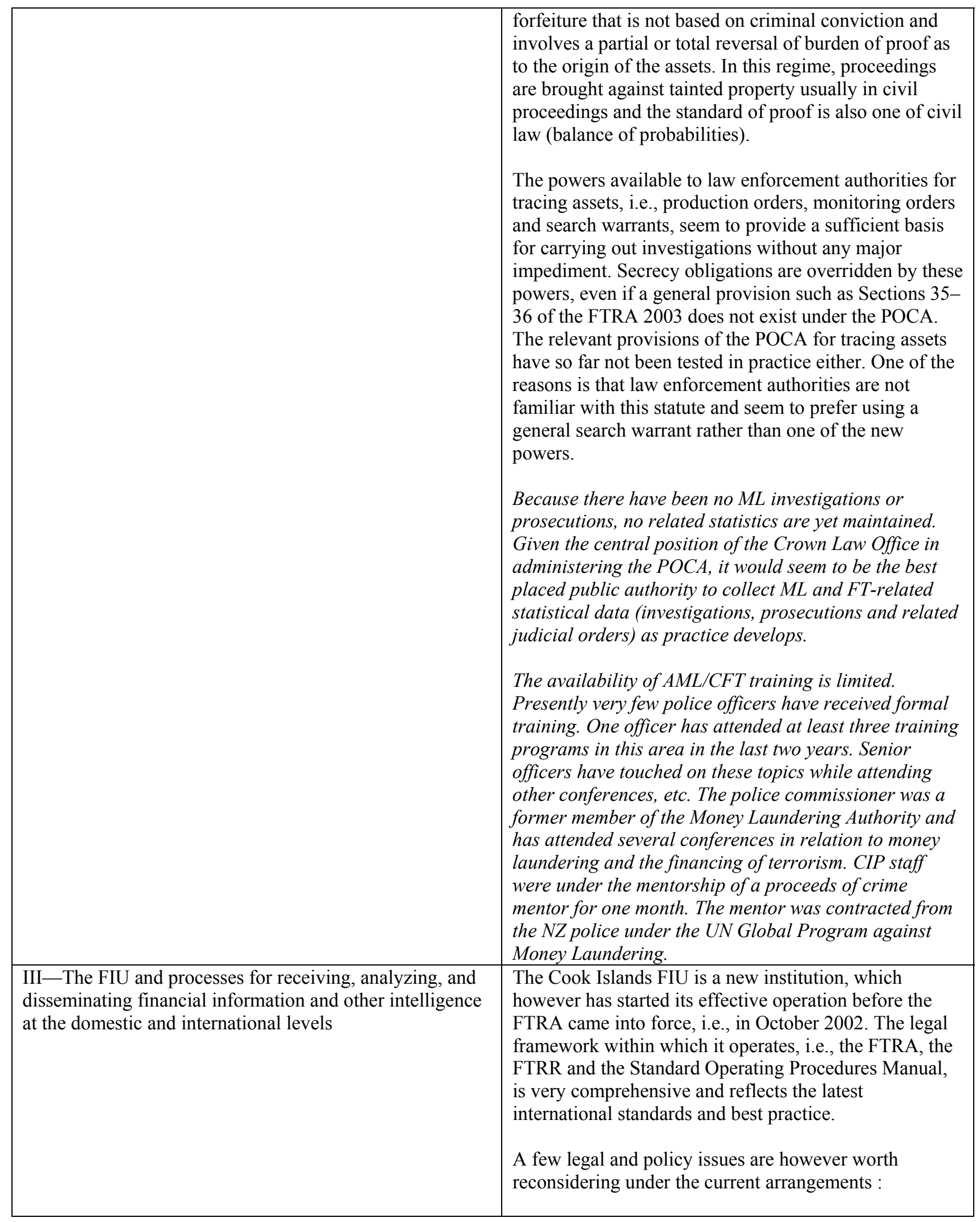


- $\quad$ taken as such, the definition of "financial institutions" in Section 2 of the FTRA is overly broad in the context of the FTRA legislation; it is assumed that the intention of the statute was to cover entities - legal persons and individuals - that need to take the required due diligence measures under the FTRA and, most importantly, to report transactions, suspicious and otherwise, rather than to (re)define "financial institutions" with a potential impact on the entire financial sector and the statutes that regulate it; it is therefore suggested to clarify that the definition covers "reporting" or "obligated" institutions.

- Section 11 (5) offers a choice for "financial institutions" to supply, when so requested by a law enforcement agency conducting an investigation, any additional information that is related to a report it had previously made to the FIU either to the FIU or to the requesting law enforcement agency. However, at the stage of criminal investigation, the requested institution should cooperate with the police or other law enforcement agency conducting the investigation, and provide to the latter, at its request, any additional documentation it may have to help the enquiry. It is unclear to the mission why the FTRA offers this choice and, specifically, why the FIU should receive the information when the reporting entity decides not to supply it to the requesting law enforcement agency. In the interest of expediency, and given the extensive powers that law enforcement agencies were provided with under the POCA to obtain disclosure of documents, it would seem to the mission that Section 11 (5) should be amended to require that the additional information be supplied directly to the law enforcement agency in charge of the investigation.

The FIU statistical figures show the number of reports received by it, but at this stage the FIU keeps no statistics on the number of reports resulting in investigations, prosecutions or convictions, or STRS materially assisting such ventures as no STR was so far forwarded to the CIP.

Besides the issue of premises, the material resources of the FIU seem to be adequate. The FIU office is equipped with IT and office equipments, though these would benefit from upgrading. The budget of the FIU is sufficient for the present structure and workload, but it may not be enough if all statutory FIU functions are to be carried out in combination with its default policy 


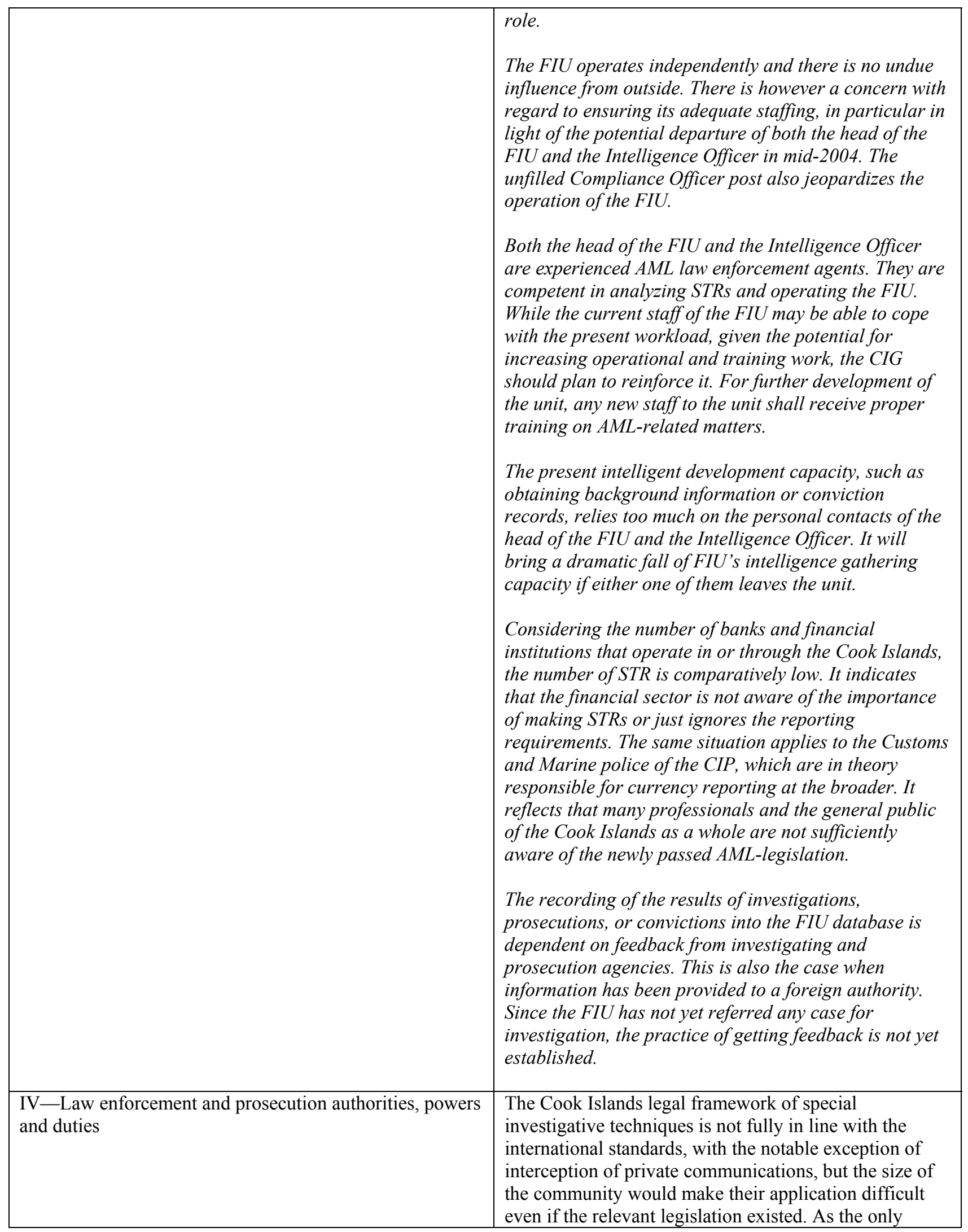


"special" investigative technique that is at present set forth in legislation is the interception of private communications, which has not yet been applied in practice for lack of required technology, the mission is not in a position to assess their effectiveness. However, it notes that conditions of granting an interception order seem very restrictive, e.g., as regards the types of offenses in connection with which an application may be made. Consideration should be given to extending the list of offenses as practice develops and include, for example, terrorism-related offenses.

The powers available to Cook Islands law enforcement authorities for compelling production of records, through production orders, monitoring orders and search warrants, seem to provide a sufficient basis for carrying out financial investigations without any major impediment. Secrecy obligations are overridden by these powers, even if a general provision such as Sections 3536 of the FTRA does not exist under the POCA.

The mission notes, however, that at present the law enforcement authorities are not sufficiently familiar with the new powers introduced by the POCA. Training in the new legislation and the use of these powers in financial investigations therefore seems indispensable to help practice evolve.

The CLO and the CIP are designated officials responsible for prosecuting and investigating $M L$. The $S G$ has received reasonable training on $M L$ matters, but further training should however be provided to other prosecutors in the office as they will be required, at some stage, to handle ML prosecutions in court.

Following the departure of the two most experienced fraud investigators of the $C I B$, the capacity of $C I B$ in investigating financial fraud and money laundering is seriously affected. Fortunately, both officers are still working in the AML field, and thus it does not jeopardize the overall capacity of the Cook Islands in tackling the ML activities.

It is a practice that CIP will prosecute most of the criminal cases. Being a legally qualified professional, the Deputy Commissioner of Police appears to form his own legal opinion for most of the criminal investigations. Only the potential cases that involve members of the police force will be passed to the CLO. Annually, there are about 15 cases, on average, passed to CLO for legal advice and prosecution. This practice does not seem appropriate for ML cases, which always are accompanied by complex investigations and court procedures. 


\begin{tabular}{|c|c|}
\hline & 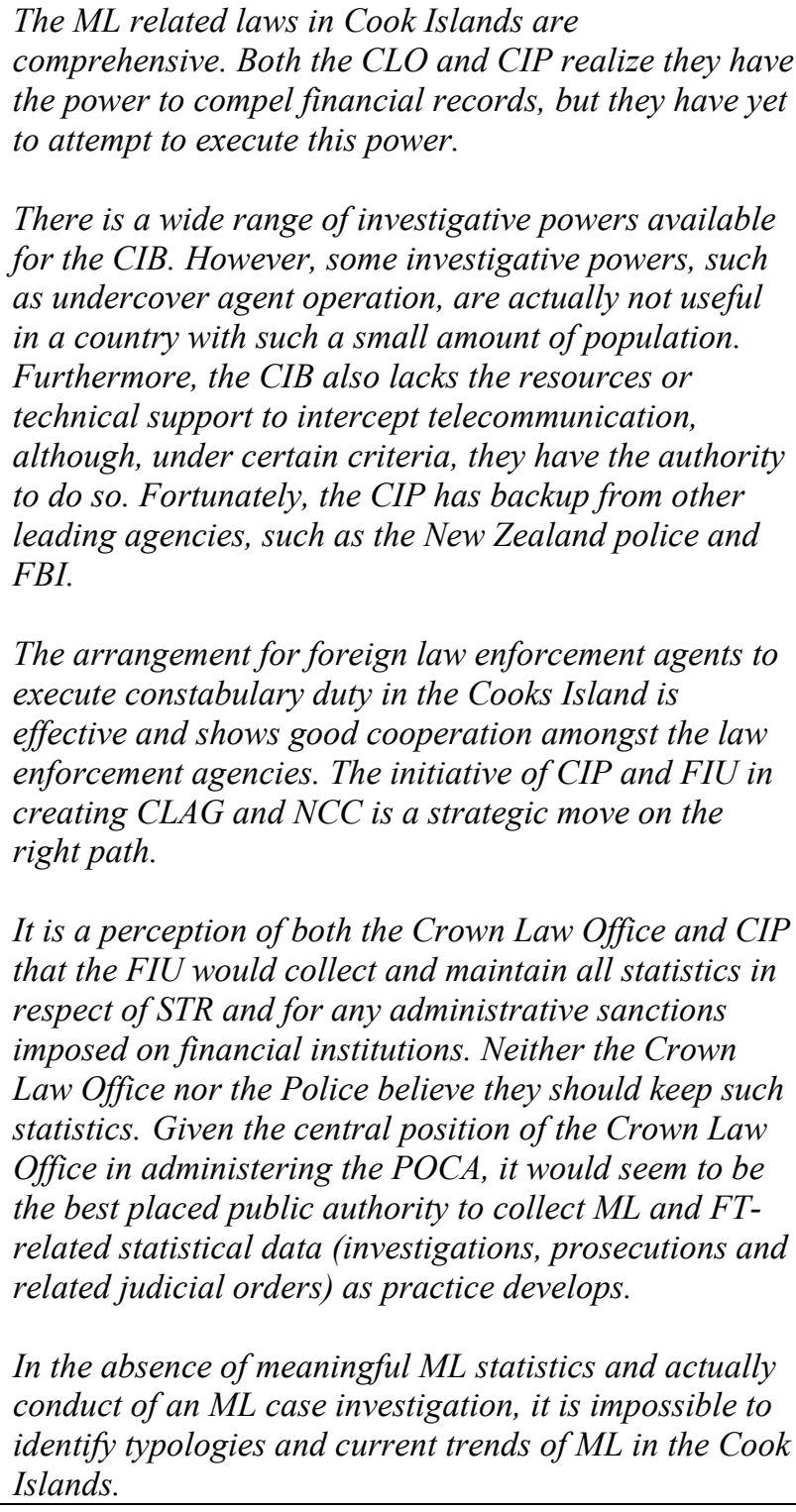 \\
\hline $\mathrm{V}$-International cooperation & $\begin{array}{l}\text { The legal provisions regulating mutual legal assistance } \\
\text { and extradition are comprehensive and are in line with } \\
\text { the latest international standards. They are, much like } \\
\text { the other parts of the AML-suite enacted in May 2003, } \\
\text { largely untested in practice, which makes any } \\
\text { meaningful assessment of their effectiveness rather } \\
\text { difficult. As practice develops, the authorities will need } \\
\text { to review carefully which portions of this legislation } \\
\text { work well and correct any deficiency that may arise. } \\
\text { The following are a few issues that may need } \\
\text { reconsideration in terms of drafting in the MACMA: }\end{array}$ \\
\hline
\end{tabular}


- $\quad$ provision or obtaining assistance under the MACMA is not limited to certain jurisdictions (Section 5), nor is the type of assistance provided or received (Section 4). It is therefore understood that cooperation may be extended to all countries without a process of prior designation. The mission also notes that the MACMA does not specifically require that a treaty, agreement or other arrangement exist for the provision or obtaining of assistance. While this may be proof of the broad authority granted by the Act to provide assistance, the mission considers that for the sake of clarity it might be helpful to explicitly include a provision in Section 4 of the MACMA to the effect that such arrangements are not necessary, subject to obtaining an assurance of reciprocity if necessary;

- the MACMA and the POCA seem to create parallel regimes for the provision of assistance to a foreign jurisdiction with regard to search, seizure, restraining and production orders that are necessary for locating, identifying tainted property related to, or the investigation of, a foreign serious offense; the mission believes that for the sake of clarity, both statutes should provide explicitly, that the execution of a request pursuant to one or the other statute is exclusive and bars ipso facto procedures under the other;

As regards extradition, the absence of criminalization of FT prevents the Cook Islands from extraditing persons sought for FT. This is a major shortcoming, which however the CIG has already identified and is planning to correct with the proposed draft Terrorism Suppression Bill (see under Criteria 1-6).

The Cook Islands has few formal requirements to enable it to cooperate internationally, therefore making it easy for other jurisdictions to cooperate with the Cook Islands.

The CIP has established a good network with foreign law enforcement agencies. The relationship is particularly close with agencies or organizations working within the Pacific region. Requests for information are usually dealt with in an expedient manner.

There was only one formal request made so far to the $C L O$, and thus present financial and human resources are sufficient for dealing with the request. However, in view of the newly introduced the POCA and the coming CFT act, the number of formal request may rise 


\begin{tabular}{|c|c|}
\hline & $\begin{array}{l}\text { significantly in a short span of time. Additional } \\
\text { resources may be needed. } \\
\text { The communication between the CLO and CIP is not } \\
\text { effective because information between these two } \\
\text { departments is exchanged through informal, personal } \\
\text { contacts only. Any change in the personal relationship } \\
\text { could disrupt the current exchange mechanism. It is } \\
\text { suggested that a more formal communication channel be } \\
\text { established at senior levels. }\end{array}$ \\
\hline \multicolumn{2}{|l|}{$\begin{array}{l}\text { Legal and Institutional Framework for All Financial } \\
\text { Institutions }\end{array}$} \\
\hline I-General framework & $\begin{array}{l}\text { The FTRA and implementing regulations, the FSC and } \\
\text { Banking Acts provide a reasonable basis for the start of } \\
\text { an AML/CFT regime in the Cook Islands. However, the } \\
\text { process has only really begun and the operation of the } \\
\text { FSC and FIU are at a very nascent stage. } \\
\text { Ensuring the effective implementation of the FATF } 40+ \\
8 \text { Recommendations is a shared responsibility between } \\
\text { the FIU and the FSC, but no lead agency has been } \\
\text { designated by the CIG to drive the implementation } \\
\text { process. While a coordination mechanism exists through } \\
\text { the NCCT Working Group, in which both the FIU and } \\
\text { the FSC participate, policy decisions do not } \\
\text { systematically involve the Working Group, nor are all } \\
\text { important legislative amendments discussed there. The } \\
\text { absence of clear consultation procedures and decision- } \\
\text { making responsibilities in this regard may jeopardize the } \\
\text { integrity of the AML regime. } \\
\text { Secrecy provisions in banking, trust and company } \\
\text { legislation were overridden by Section } 36 \text { of the FTRA, } \\
\text { though consequential amendments have not been made } \\
\text { in the statutes concerned. }\end{array}$ \\
\hline II-Customer identification & $\begin{array}{l}\text { While the implementing Regulations issued under the } \\
\text { FTRA usefully supplement the statutory AML } \\
\text { provisions in general, in the area of offering companies } \\
\text { and customer identification, the exemptions granted by } \\
\text { the FTRR clearly contradict the FTRA's relevant } \\
\text { provisions. This conflict of law is rather unfortunate and } \\
\text { may defeat the purpose of enacting primary legislation. } \\
\text { The mission believes that the traditional principle of } \\
\text { hierarchy of legal norms should not be challenged, } \\
\text { unless at the expense of upholding the rule of law in the } \\
\text { Cook Islands. Further, the definitions in the various } \\
\text { regulations on "licensed" or "regulated" financial } \\
\text { institutions appear to overlap and contradict each other } \\
\text { as well as statutory provisions governing the same } \\
\text { matter. These contradictions may lead to confusion as to } \\
\text { what a financial institution is actually supposed to do or } \\
\text { not to do. }\end{array}$ \\
\hline
\end{tabular}




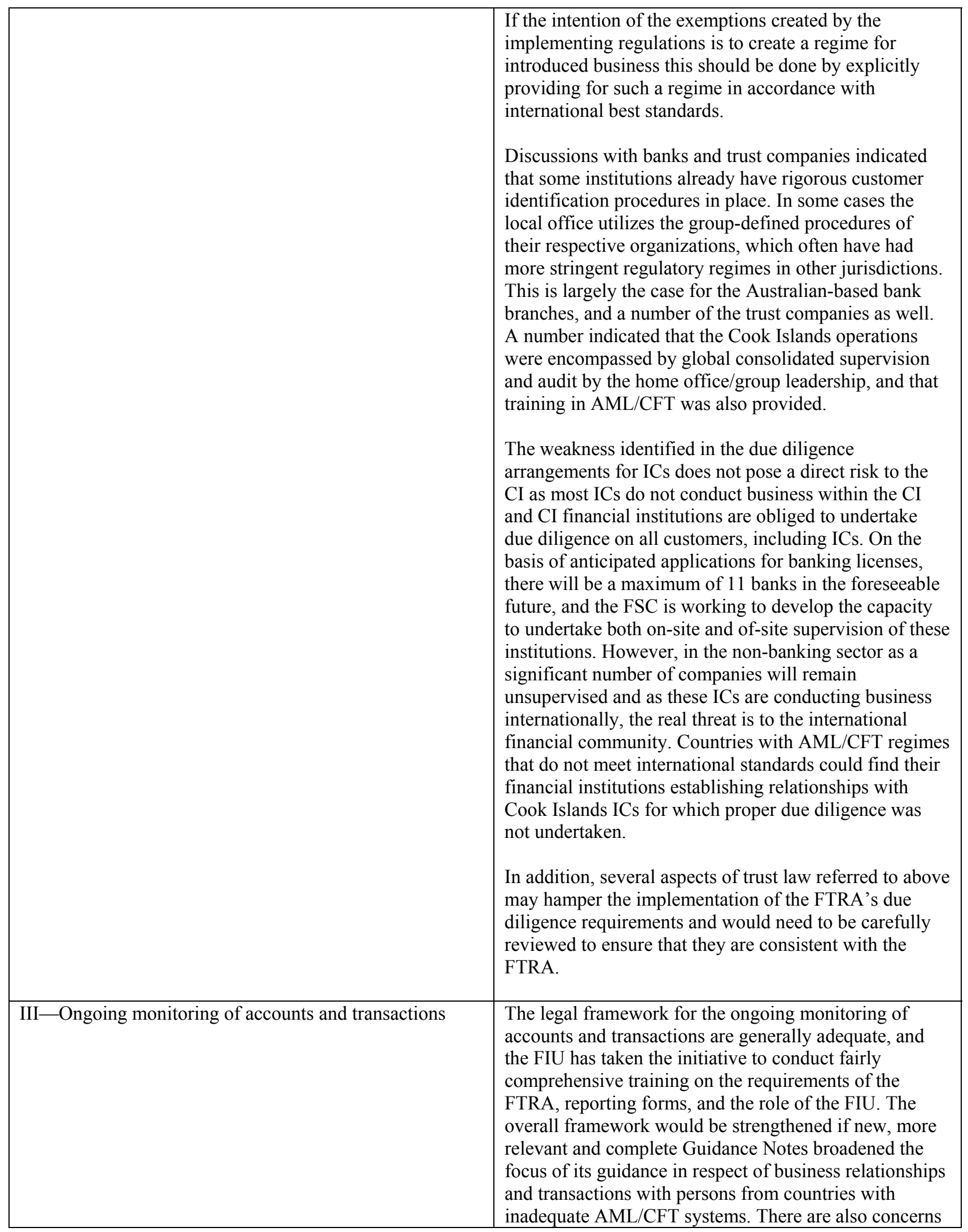




\begin{tabular}{|c|c|}
\hline & $\begin{array}{l}\text { with respect to enhanced scrutiny to wire transfers and } \\
\text { reporting of unusual or complex transactions from these } \\
\text { countries. }\end{array}$ \\
\hline IV_-Record keeping & $\begin{array}{l}\text { The guidance for record keeping contained in the FTRA } \\
\text { is quite extensive, but lacks clarity in some areas. For } \\
\text { example, since section } 6 \text { (2) provides further details of } \\
\text { requirements for transaction records, the reference } \\
\text { contained in this section should be to subsection (1) (a) } \\
\text { and not subsection (1). Also since section } 6 \text { (4) is also } \\
\text { providing further requirements about transaction } \\
\text { records, it would be useful if this were not a separate } \\
\text { subsection but a continuation of section } 6 \text { (3). } \\
\text { Actual practices in the institutions appear to be at least } \\
\text { as stringent as the FTRA requirements, and in some } \\
\text { cases surpass the minima. } \\
\text { As of yet there has not been any checking of the } \\
\text { compliance systems, so the overall effectiveness of } \\
\text { implementation has not been documented. The banks } \\
\text { with which meetings were held appear to be operate in } \\
\text { compliance with record keeping requirements of the } \\
\text { FTRA. }\end{array}$ \\
\hline $\mathrm{V}$-Suspicious transactions reporting & $\begin{array}{l}\text { The systems in place at this time are generally adequate } \\
\text { for ML, but they do not cover FT. However, to date } \\
\text { there have been no STRs forwarded to the FIU since the } \\
\text { June } 2003 \text { enactment of the standard forms. This would } \\
\text { suggest either there is a lack of understanding of } \\
\text { suspicion, or that there is some other issue causing } \\
\text { financial institutions to withhold potential reports. } \\
\text { The current tipping-off provisions of the FTRA seem } \\
\text { adequate and provide the necessary protections. } \\
\text { Any potential amendment of the tipping-off provisions } \\
\text { seeking to exempt disclosure of information between } \\
\text { financial institutions about an STR being made to the } \\
\text { FIU would be contrary to the very purpose of the FTRA. }\end{array}$ \\
\hline VI-Internal controls, compliance and audit & $\begin{array}{l}\text { The general framework for internal controls, } \\
\text { compliance, and audit are in place in the FTRA and the } \\
\text { FSCA, and there is a regulation on Compliance Officer } \\
\text { Qualifications that provides a brief experience } \\
\text { requirement. However neither the FTRA nor the FSC } \\
\text { Act explicitly require that institutions apply AML/CFT } \\
\text { requirements to branches and majority owned } \\
\text { subsidiaries located abroad. }\end{array}$ \\
\hline VII-Integrity standards & $\begin{array}{l}\text { The establishment of the FSC is an extremely important } \\
\text { first step in the effort to improve the prudential } \\
\text { regulation and AML/CFT oversight regime in the Cook } \\
\text { Islands. However, as yet there have been few } \\
\text { operational steps to implement comprehensive }\end{array}$ \\
\hline
\end{tabular}




\begin{tabular}{|c|c|}
\hline & $\begin{array}{l}\text { compliance and enforcement activities. This is certainly } \\
\text { due to the newness of the institution, and it is recognized } \\
\text { that such measures will take time to develop and } \\
\text { implement. At this time, other than domestic banking, } \\
\text { the rest of the financial sector is either under lax } \\
\text { regulatory regime or under no government supervision. } \\
\text { For certain financial institutions under government } \\
\text { licensing, such as trust companies and insurers, the } \\
\text { licensing requirement does not specifically refer to a fit- } \\
\text { and-proper test. While the Integrity Standards set out } \\
\text { under the Banking Act } 2003 \text { are generally sound and } \\
\text { rigorous, the acts governing the other regulated } \\
\text { institutions have not been similarly updated to reflect } \\
\text { the modern concerns and practices relative to these } \\
\text { standards. Other financial institutions as defined by the } \\
\text { FTRA are not regulated by the FSC and are not required } \\
\text { to obtain a license. }\end{array}$ \\
\hline VIII_-Enforcement powers and sanctions & $\begin{array}{l}\text { The legal framework provides ample enforcement } \\
\text { authority for the FSC to take enforcement action against } \\
\text { institutions that do not have or maintain adequate } \\
\text { compliance systems. However, until a meaningful } \\
\text { compliance checking system is put in place at least in } \\
\text { the traditional financial sector, these enforcement } \\
\text { powers will remain virtual. }\end{array}$ \\
\hline $\begin{array}{l}\text { IX-Cooperation between supervisors and other } \\
\text { competent authorities }\end{array}$ & $\begin{array}{l}\text { The framework for cooperation with supervisory } \\
\text { authorities is generally adequate. The FSC does no } \\
\text { however appear to have an adequate level of trained } \\
\text { resources to cover AML/CFT as well as all other areas } \\
\text { of risk. Likewise, the FIU is not presently equipped to } \\
\text { carry out its mandated compliance audits of } \\
\text { nonregulated financial institutions as defined under the } \\
\text { FTRA. Some concern exists relative to the legislative } \\
\text { authorization of higher levels of cooperation by the FSC } \\
\text { with other domestic authorities in the conduct of } \\
\text { investigations. }\end{array}$ \\
\hline
\end{tabular}


Table 9. Recommended Action Plan to Improve the Legal and Institutional Framework and to Strengthen the Implementation of AML/CFT Measures in Banking, Insurance and Securities Sectors

\begin{tabular}{|c|c|}
\hline $\begin{array}{l}\text { Criminal Justice Measures and International } \\
\text { Cooperation }\end{array}$ & Recommended Action \\
\hline $\mathrm{I}-$ Criminalization of ML and FT & 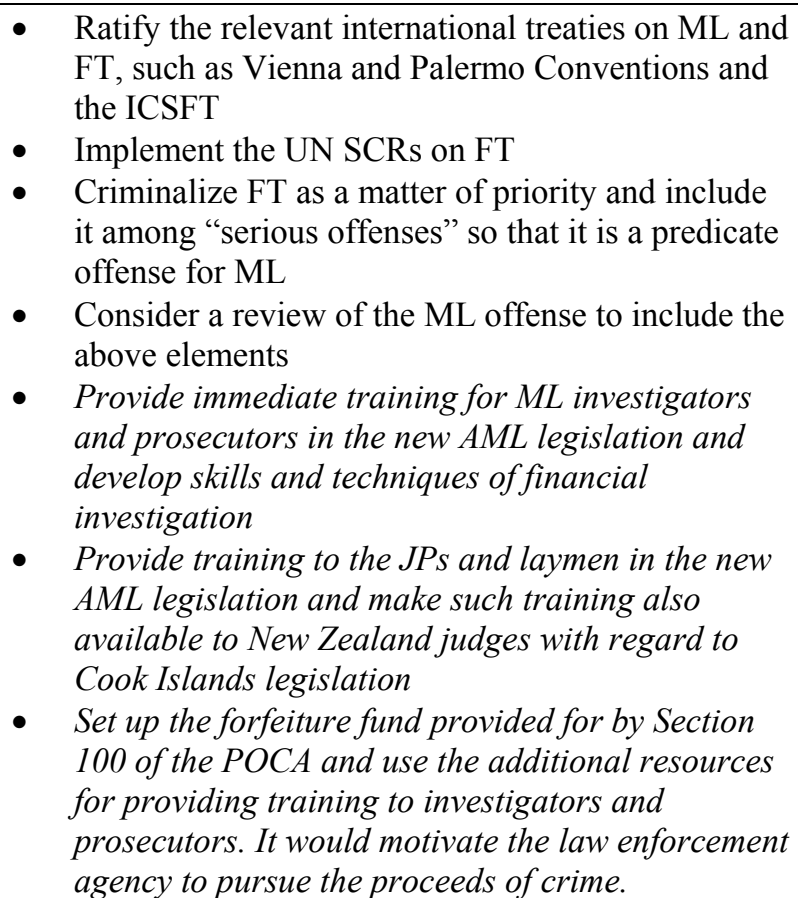 \\
\hline $\begin{array}{l}\text { II-Confiscation of proceeds of crime or property used to } \\
\text { finance terrorism }\end{array}$ & $\begin{array}{l}\text { Make criminal forfeiture mandatory for any serious } \\
\text { offense where proceeds are detected; } \\
\text { Consider simplifying the confiscation regime. As } \\
\text { practice develops with the application of forfeiture } \\
\text { and pecuniary penalty orders, consider, for } \\
\text { example, extending the scope of forfeiture orders } \\
\text { to benefits as well. As a result, unless practice } \\
\text { reveals that pecuniary penalty orders serve a } \\
\text { specific purpose that could not be achieved by } \\
\text { forfeiture orders, they could be dispensed with; } \\
\text { Consider introducing a civil (i.e., nonconviction } \\
\text { based and noncriminal) forfeiture regime; } \\
\text { Adopt as matter of priority legislation that provides } \\
\text { for the freezing of terrorist funds and enables the } \\
\text { effective implementation of UN SCRs on FT; } \\
\text { Ensure, if necessary by issuing regulation, that the } \\
\text { CIG regularly circulate UN and other terrorist } \\
\text { watch-lists to financial institutions and keeps them } \\
\text { abreast of new developments; } \\
\text { Consider amending the POCA in order to enable } \\
\text { the forfeiture of property of organizations that are } \\
\text { found to be primarily criminal in nature; } \\
\text { Make AML/CFT training mandatory for all law } \\
\text { enforcement personnel, in particular prosecutors }\end{array}$ \\
\hline
\end{tabular}


III-The FIU and processes for receiving, analyzing, and disseminating financial information and other intelligence at the domestic and international levels and police officers, who may be involved in the investigation and prosecution of ML and FT offenses; the training should specifically cover the implementation of the POCA and use of its specific powers;

- Ensure that the Crown Law Office is responsible for representing t the Cook Islands authorities in all restraining and forfeiture order applications and hearings. It should also be designated as the central body to keep relevant statistics;

- To make better use of the limited resources, officers who have received AML/CFT training should be designated as AML/CFT trainers and conduct regular AML/CFT training to both the public and private sectors in order to involve them in the AML/CFT process;

The CIP should include the AML/CFT regime into its basic training program for new recruits. This would serve the purposes of raising awareness on AML/CFT matters amongst law enforcement agents and introducing the new legal concepts for future detectives.

- Amend definition of "financial institutions" to "reporting institutions" in Section 2 of the FTRA 2003;

- Amend Section 11 (5) so that the additional information is supplied to the requesting law enforcement agency directly only;

- In light of the pending expiration of the contracts of the Head of the FIU and the Intelligence Officer, immediate arrangements should be made to ensure that these positions continue to be filled by persons of appropriate qualifications and experience.

- $\quad$ The post of FIU Compliance Officer should be filled as soon as practicable;

- $\quad$ The FIU should establish formal channels of communication, on unit-to-unit basis, for obtaining and sharing information with domestic and overseas agencies;

- $\quad$ The FIU should maintain close liaison with the CIP and pass to the CIP any substantiated intelligence of potential serious crime, ML and FT as required by the FTRA;

The FIU database should be further enhanced with reporting capacity and include the results and feedback to and from the agency. 


\begin{tabular}{|c|c|}
\hline $\begin{array}{l}\text { IV-Law enforcement and prosecution authorities, powers } \\
\text { and duties }\end{array}$ & $\begin{array}{l}\text { - Consider expanding the list of criminal offenses } \\
\text { for which the interception of private } \\
\text { communications under Section 96A would be } \\
\text { available; } \\
\text { With the departure of the two experienced fraud } \\
\text { investigators, immediate training should be } \\
\text { provided for the only remaining fraud investigator } \\
\text { in the CIB. Should resources be available, training } \\
\text { should also be given for other detectives in the } \\
\text { CIB; } \\
\text { Similar training should also be given for } \\
\text { prosecutors of the Crown Law Office; } \\
\text { The Crown Law Office should be designated as } \\
\text { responsible for collecting and keeping ML-related } \\
\text { statistics; } \\
\text { The FIU, CIP, and Crown Law Office should select } \\
\text { amongst the STRs and try to develop a possible ML } \\
\text { case, in order to test the capacity of all these units } \\
\text { and provide a chance to gain experience for the } \\
\text { officers involved. }\end{array}$ \\
\hline $\mathrm{V}$-International cooperation & $\begin{array}{l}\text { Ratify the relevant international treaties in the area } \\
\text { of ML and FT, such as the Vienna and Palermo } \\
\text { Conventions and the ICSFT and ensure that } \\
\text { domestic legislation is in place for their } \\
\text { implementation, in particular with regard to the } \\
\text { criminalization of FT; } \\
\text { Consider including a provision in MACMA to } \\
\text { expressly permit mutual legal assistance in the } \\
\text { absence of treaty, agreement or other arrangement, } \\
\text { on a discretionary basis, if necessary with an } \\
\text { assurance of reciprocity; } \\
\text { Monitor the practical effectiveness of the MACMA } \\
\text { and the POCA statutes in permitting recognition of } \\
\text { foreign forfeiture and confiscation orders and } \\
\text { consider expanding recognition to nonconviction } \\
\text { based (civil) forfeiture orders; } \\
\text { The Police should be aware of the international } \\
\text { cooperation requirements of the AML legislation, } \\
\text { for example, pursuant to the POCA, the MACMA } \\
\text { and the new EA; } \\
\text { Coordination between the CIP and CLO needs } \\
\text { improvement. }\end{array}$ \\
\hline \multicolumn{2}{|l|}{$\begin{array}{l}\text { Legal and Institutional Framework for Financial } \\
\text { Institutions }\end{array}$} \\
\hline I-General framework & $\begin{array}{l}\text { For the sake of clarity, the statutes referred to at } \\
\text { Section } 36 \text { of the FTRA should be amended } \\
\text { accordingly to reflect the superior interest of AML } \\
\text { enforcement over secrecy provisions; } \\
\text { - A lead agency should be designated to coordinate } \\
\text { and ensure the implementation of the overall AML } \\
\text { regime; } \\
\text { - Any policy decision in the area of AML should }\end{array}$ \\
\hline
\end{tabular}




\begin{tabular}{|c|c|}
\hline & $\begin{array}{l}\text { involve the inter-agency consultation and decision- } \\
\text { making process. } \\
\text { The policy process would be strengthened by the re- } \\
\text { casting of the Working Group as a policy-making body } \\
\text { to lead both the FIU and FSC in terms of approach to } \\
\text { development of the AML/CFT regime. } \\
\text { Basic compliance examination procedures should be } \\
\text { developed as a pilot exercise, perhaps with a } \\
\text { combination of FIU and FSC staff, and rolled out with a } \\
\text { sample set institutions to gauge compliance with all of } \\
\text { the relevant requirements of the FTRA and determine } \\
\text { the need for future action and/or guidance. } \\
\text { The authorities should finalize and issue detailed } \\
\text { AML/CFT guidance Notes for all reporting institutions. }\end{array}$ \\
\hline II-Customer identification & $\begin{array}{l}\text { The FSC should develop a compliance program } \\
\text { that encompasses all regulated financial } \\
\text { institutions as soon as possible, as at present the } \\
\text { state of the development of compliance regimes, } \\
\text { internal controls, and other aspects/elements of } \\
\text { an AML/CFT program at other than one } \\
\text { domestic bank is unknown; } \\
\text { Furthermore, Part } 6 \text { exempts CID requirements } \\
\text { for transactions from any foreign regulated } \\
\text { institution, which diminishes the value of } \\
\text { maintaining an AML/CFT framework. This } \\
\text { conflict between the FTRR and the statutory } \\
\text { provisions of the FTRA should be resolved as a } \\
\text { matter of priority by eliminating any provision in } \\
\text { the Regulations that diminishes the scope of the } \\
\text { identification requirements set forth by the } \\
\text { FTRA; } \\
\text { Guidance should be issued that directs reporting } \\
\text { institutions to take special care when conducting } \\
\text { transactions with institutions residing in } \\
\text { countries with weak AML/CFT compliance } \\
\text { regimes; } \\
\text { The notion of "approved jurisdictions" seems } \\
\text { overly broad and does not guarantee that } \\
\text { introducers maintain international best practice, } \\
\text { and should therefore be avoided; } \\
\text { The draft } 2003 \text { Guidance notes should be } \\
\text { adapted to reflect recently enacted laws and } \\
\text { regulations, and then formally promulgated; } \\
\text { mechanism to undertake meaningful supervisory } \\
\text { surveillance of trustee companies and the } \\
\text { Registrar of Companies should ensure that the } \\
\text { beneficial owners of ICs are identified, verified } \\
\text { and this information is kept updated; } \\
\text { - it protocols be established to }\end{array}$ \\
\hline
\end{tabular}




\begin{tabular}{|c|c|}
\hline & $\begin{array}{l}\text { ensure that best international practices for } \\
\text { "introduced business" are followed throughout } \\
\text { the business relationship; } \\
\text { The CID regulation should be amended to } \\
\text { require that any financial institution that } \\
\text { accepts business from a third party must: } \\
\text { a) satisfy itself that the third party is regulated and } \\
\text { supervised for, and has measures in place to } \\
\text { comply with the provision of Section } 4 \text { of the } \\
\text { FTRA; } \\
\text { b) should immediately obtain the necessary } \\
\text { information required under Section } 4 \text { of the FTRA; } \\
\text { and } \\
\text { c) should take adequate steps to satisfy themselves } \\
\text { that copies of identification data and other relevant } \\
\text { documentation required under Part } 2 \text { of CID will } \\
\text { be made available from the third party upon } \\
\text { request without delay; } \\
\text { Implementing a framework for introduced business } \\
\text { as outlined above will require a level of } \\
\text { supervisory sophistication that is beyond the } \\
\text { current capacity of the FSC. The adoption of a } \\
\text { regime should therefore be deferred until such time } \\
\text { that the requisite supervisory capacity is developed } \\
\text { by the FSC or is available through other means. } \\
\text { Certain aspects of trust law need to be carefully } \\
\text { reviewed to ensure that they are consistent with the } \\
\text { FTRA's due diligence requirements. }\end{array}$ \\
\hline III-Ongoing monitoring of accounts and transactions & $\begin{array}{l}\text { - The FIU and/or the FSC should issue the draft } \\
\text { guidance notes that address enhanced scrutiny for } \\
\text { noncompliant countries. } \\
\text { Further training in patterns and practices } \\
\text { of suspicious activities would be } \\
\text { beneficial. } \\
\text { In addition to the initial efforts made by the FIU, the } \\
\text { FSC and the FIU should also develop permanent } \\
\text { systems to warn reporting institutions of countries which } \\
\text { do not have adequate AML/CFT systems and to provide } \\
\text { other relevant information such as lists published by the } \\
\text { Counter Terrorism Committee of the UN Security } \\
\text { Council. The system should include a mechanism to } \\
\text { update previous notices as new information becomes } \\
\text { available. }\end{array}$ \\
\hline IV-Record keeping & $\begin{array}{l}\text { The wording of section } 6(2) \text { of the FTRA should be } \\
\text { amended to read as follows: } \\
\text { "Records required under section (1) (a) are those records } \\
\text { that are reasonably necessary to enable the transaction to } \\
\text { be readily reconstructed at any time by the FIU or by a } \\
\text { law enforcement agency." }\end{array}$ \\
\hline
\end{tabular}




\begin{tabular}{|c|c|}
\hline & $\begin{array}{l}\text { The following wording should replace the current section } \\
6(4) \text { of the FTRA, should not be a separate subsection } \\
\text { and should follow immediately after section } 6(3)(\mathrm{b}) \text { : } \\
\text { "As well as the documents used by the financial } \\
\text { institution to identify and verify the identity of each such } \\
\text { person." } \\
\text { The FSC should undertake an initial process to determine } \\
\text { whether banks have adequate record-keeping systems } \\
\text { and procedures to provide assurance that compliance will } \\
\text { be maintained. }\end{array}$ \\
\hline $\mathrm{V}$-Suspicious transactions reporting & $\begin{array}{l}\text { - The suspicious transaction reporting system should } \\
\text { be extended to FT } \\
\text { The FIU and FSC should open up further dialog } \\
\text { with financial institutions to determine the level of } \\
\text { understanding of suspicious activity concepts to } \\
\text { identify potential gaps or bottlenecks in the } \\
\text { process. Initiatives toward this end should also } \\
\text { focus on clarifying what constitutes the tipping off } \\
\text { of a customer. } \\
\text { The draft } 2003 \text { Guidance Notes should be updated } \\
\text { against the new legislation and issued as soon as } \\
\text { possible. } \\
\text { The FIU should continue its training efforts to } \\
\text { reinforce the actions that have already taken place, } \\
\text { particularly by providing training in the } \\
\text { recognition of suspicious transactions. }\end{array}$ \\
\hline VI-Internal controls, compliance and audit & $\begin{array}{l}\text { The FIU/FSC should consider providing more } \\
\text { descriptive guidance on audit system components } \\
\text { for AML/CFT compliance systems, as well as } \\
\text { more detailed guidance on the skills requirements } \\
\text { for Compliance Officers appointed by financial } \\
\text { institutions. } \\
\text { There should be legal/regulatory guidance } \\
\text { provided to promote sound practices when vetting } \\
\text { employees who may assume higher-risk positions } \\
\text { within institutions. } \\
\text { It would likely be useful to provide more } \\
\text { descriptive guidance on the role of Compliance } \\
\text { Officers and Money Laundering Reporting } \\
\text { Officers, and what are acceptable combinations } \\
\text { and divisions of duties in practice. } \\
\text { As part of a risk assessment exercise, the FSC } \\
\text { should seek to determine and document the } \\
\text { training practices of institutions to help identify } \\
\text { those that pose lower risk. This would further aid } \\
\text { in allocating resources to higher risk institutions. } \\
\text { The FSC should indicate that financial institutions } \\
\text { are expected to apply AML/CFT requirements to }\end{array}$ \\
\hline
\end{tabular}




\begin{tabular}{|c|c|}
\hline & $\begin{array}{l}\text { branches and majority owned subsidiaries located } \\
\text { abroad. This should be reinforced through the } \\
\text { Guidance Notes and the FSC 's surveillance } \\
\text { activities. }\end{array}$ \\
\hline VII-Integrity standards & $\begin{array}{l}\text { - It would be useful for the laws governing } \\
\text { nonbank regulated financial institutions to be } \\
\text { updated and rationalized to provide a similar } \\
\text { standard as those applied to banks with respect } \\
\text { to prudential matters. } \\
\text { The FIU/FSC should issue guidelines that } \\
\text { address the need for the performance of } \\
\text { background checks for persons in sensitive } \\
\text { positions relative to potential money laundering } \\
\text { activities. } \\
\text { The current regulatory framework should be } \\
\text { strengthened to better address the regulation of } \\
\text { charities and non-profits and shell companies. } \\
\text { The government should introduce statutory fit- } \\
\text { and-proper tests for directors, managers, and } \\
\text { significant shareholders at the time of } \\
\text { licensing/change in ownership of all regulated } \\
\text { financial institutions similar to those contained } \\
\text { in the banking law. In addition, the fit-and- } \\
\text { proper test should be made an ongoing } \\
\text { requirement. }\end{array}$ \\
\hline VIII-Enforcement powers and sanctions & $\begin{array}{l}\text { The FSC should seek to implement a compliance } \\
\text { program for regulated institutions. } \\
\text { The authorizing legislation for nonbank financial } \\
\text { institutions should be revised to reflect a similar } \\
\text { approach and level of enforcement authority as } \\
\text { provided in the banking law for banking institutions. }\end{array}$ \\
\hline $\begin{array}{l}\text { IX-Cooperation between supervisors and other } \\
\text { competent authorities }\end{array}$ & $\begin{array}{l}\text { The level of resources in the FSC's Supervisory } \\
\text { Division should be assessed once the } \\
\text { rationalization of licensing has been completed to } \\
\text { ensure it has adequate human and other resources } \\
\text { to carry out its supervisory and compliance role. } \\
\text { The FIU's Compliance Officer Position should be } \\
\text { filled to ensure that all areas of risk related to the } \\
\text { operation of licensed institutions are adequately } \\
\text { covered. } \\
\text { The basis and extent of compliance of the FSC } \\
\text { with other domestic authorities should be expanded } \\
\text { in the FSC Act. } \\
\text { As part of the FSC's overall development it } \\
\text { would be helpful to set forth a strategic plan } \\
\text { specifically addressing AML/CFT issues to be } \\
\text { included among the other supervisory initiatives it } \\
\text { must undertake. This would include performing a } \\
\text { risk assessment of regulated institutions to aid in } \\
\text { the allocation/prioritization of examination } \\
\text { resources, as well as key steps needed to develop }\end{array}$ \\
\hline
\end{tabular}




\begin{tabular}{|l|l|}
\hline & \multicolumn{1}{|c|}{$\begin{array}{l}\text { appropriate supervisory guidance and procedures. } \\
\text { This exercise could be conducted in cooperation } \\
\text { with the FIU to enable the sharing of information, } \\
\text { techniques, and resources. }\end{array}$} \\
\hline Banking Sector based on Sector-Specific Criteria & \multicolumn{1}{|c|}{} \\
\hline II—Customer identification & See recommendations in detailed assessment. \\
\hline III-Ongoing monitoring of accounts and transactions & See recommendations in detailed assessment. \\
\hline IV-Record keeping & See recommendations in detailed assessment. \\
\hline VI-Internal controls, compliance and audit & See recommendations in detailed assessment. \\
\hline VIII-Enforcement powers and sanctions & See recommendations in detailed assessment. \\
\hline $\begin{array}{l}\text { IX-Cooperation between supervisors and other } \\
\text { competent authorities }\end{array}$ & See recommendations in detailed assessment. \\
\hline Insurance Sector based on Sector-Specific Criteria & \\
\hline II-Customer identification & Develop regime for the supervision of insurance entities. \\
\hline III-Ongoing monitoring of accounts and transactions & Develop regime for the supervision of insurance entities. \\
\hline IV-Record keeping & Develop regime for the supervision of insurance entities. \\
\hline V-Suspicious transaction reporting & Develop regime for the supervision of insurance entities. \\
\hline VI-Internal controls, compliance and audit & Develop regime for the supervision of insurance entities. \\
\hline Securities Sector based on Sector-Specific Criteria & \\
\hline II-Customer identification & \\
\hline IV-Record keeping & \\
\hline VI-Internal controls, compliance and audit & \\
\hline VII-Integrity standards & \\
\hline VIII-Enforcement powers and sanctions & \\
\hline $\begin{array}{l}\text { IX-Cooperation between supervisors and other } \\
\text { competent authorities }\end{array}$ & \\
\hline
\end{tabular}

